\title{
Receptor mimetikumok és ligandumaik \\ kölcsönhatásának modellezése szilárd/folyadék határfelületen
}

Doktori (Ph.D.) értekezés

Juhász Ádám

okleveles vegyész

Témavezetők:

Dr. Dékány Imre professzor emeritus

Dr. Tóth Gábor egyetemi tanár

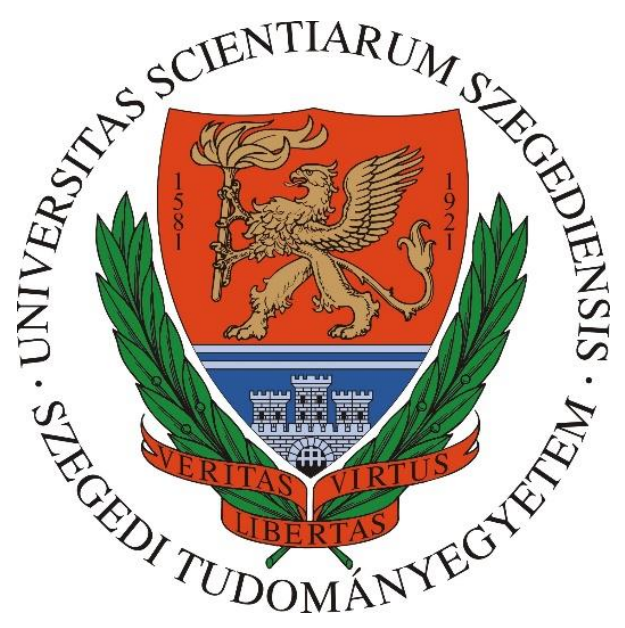

Kémia Doktori Iskola

Szegedi Tudományegyetem

Természettudományi és Informatikai Kar

Fizikai Kémiai és Anyagtudományi Tanszék

Szeged 


\section{Tartalomjegyzék}

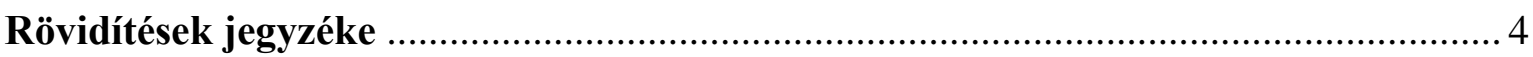

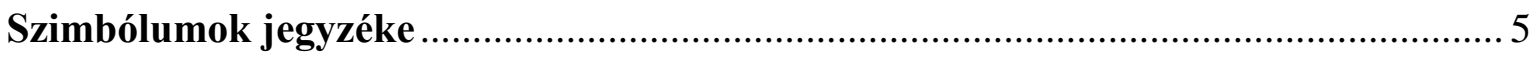

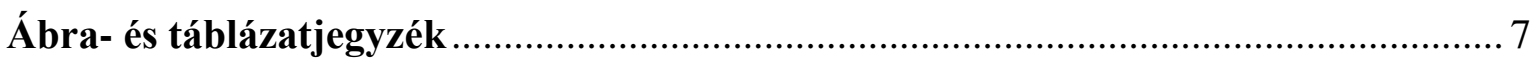

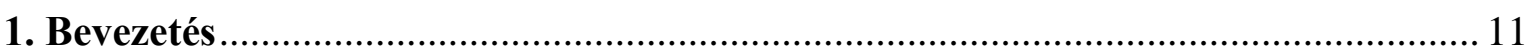

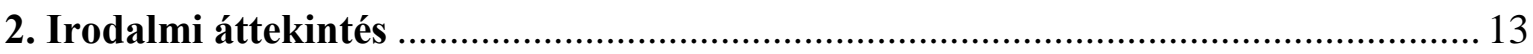

2.1. A felületi plazmon rezonancia jelenségének fizikai magyarázata és a jelenség

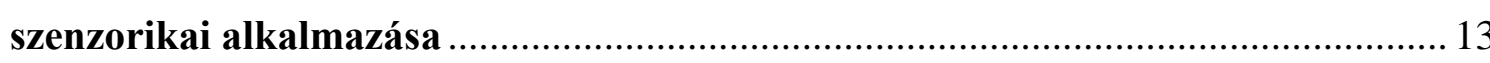

2.1.1. Az evaneszcens hullám és az evaneszcens tér .............................................. 14

2.1.2. Diszperziós összefüggések és a felületi plazmonok gerjesztése ......................... 17

2.1.3. A felületi plazmonok gerjesztésének következménye ........................................ 20

2.1.4. Az SPR szenzorok alkalmazása a kémiai analízisben .................................... 23

2.2. A tanulmányozott kinurenin rendszer szerepe ............................................ 27

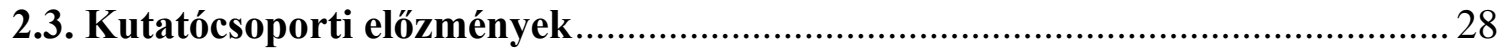

2.3.1. Az AMPA receptort modellezö polipeptidek szintézise és karakterizálása ......... 30

2.3.2. Az SPR szenzor felületének funkcionalizálása AMPA receptort modellezö

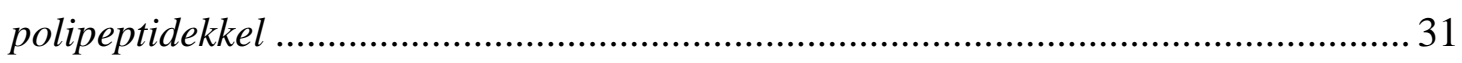

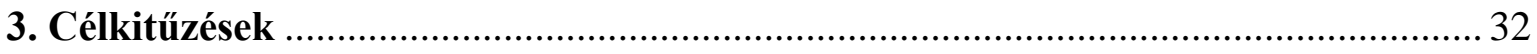

4. Felhasznált anyagok és vizsgálati módszerek …................................................. 33

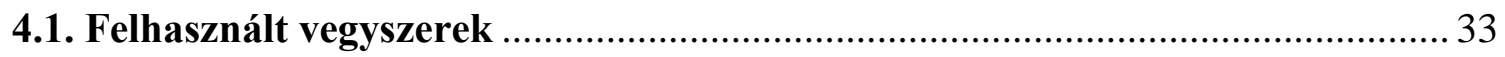

4.2. A kísérletek során alkalmazott vizsgálati módszerek ..................................... 34

4.2.1. Felületi plazmon rezonancia (SPR) spektroszkópia ......................................... 34

4.2.2. Kvarckristály mikromérleg (QCM) technika ................................................. 36

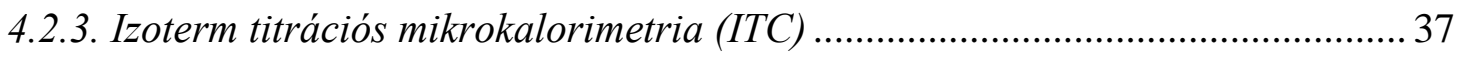

4.2.4. Kisszögü röntgenszórásos (SAXS) szerkezetvizsgálat .................................... 38

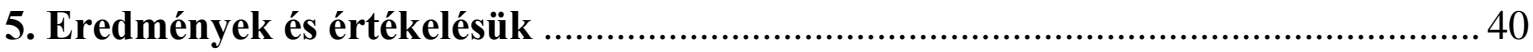

5.1. Cisztein-tartalmú di- és tripeptidek valamint fehérjék adszorpciója arany felületen. 
5.1.1. Arany felülethez irreverzibilisen kötődö molekulák immobilizálása SPR szenzor felületén 40

5.1.2. Arany felülethez irreverzibilisen kötödö molekulák immobilizálása QCM szenzor felületén

5.1.3. Szérum fehérjék és lizozim geometriai jellemzőinek meghatározása SAXS vizsgálatok alapján.

5.2. Fehérje (BSA)-alapú kolloidális gyógyszerhordozó és hatóanyaga (IBU) közötti kölcsönhatás szilárd/folyadék határfelületen kivitelezett modellezése 49

5.2.1. A gyógyszerhordozó SAXS, ITC és SPR technikák általi jellemzése. 50

5.2.2. A hatóanyag szilárd/folyadék határfelületen végbemenö megkötődését jellemző sebességi állandók meghatározása az SPR szenzorgramok illesztésével.

5.3. Az AMPA receptort modellező (GluR1 270-300) polipeptid és a KYNA kölcsönhatásának modellezése SPR szenzorfelületen

5.3.1. Az AMPA receptor alegységet modellezö GluR1 270-300 polipeptid szintézise és karakterizálása....

5.3.2. Az SPR szenzor felületének funkcionalizálása GluR $1_{270-300 ~}$ polipeptiddel 60

5.3.3. A KYNA szilárd/folyadék határfelületi adszorpciójának vizsgálata GluR1270-300 polipeptiddel funkcionalizált szenzorfelületen

5.3.4. A KYNA szenzorfelületen immobilizált GluR1 270-300 polipeptiden végbemenö reverzibilis kötödésének kinetikai vizsgálata

5.3.5. A KYNA szenzorfelületen immobilizált GluR1 270-300 polipeptiden végbemenö reverzibilis kötödésének van't Hoff analízise.

\subsection{AMPA receptort modellező (GluR1 231-259) polipeptid és KYNA}

5.4.1. A szenzorfelület kialakitása, valamint a KYNA és GluR1 231-259 polipeptid alkotta kötési komplex keletkezését jellemzö sebességi állandók meghatározása 74 5.4.2. A KYNA és az AMPA receptort modellezö GluR1 $231-259$ polipeptid alkotta kötési komplex keletkezésének van't Hoff analizise.

5.5. Szérum fehérjék (BSA, HSA) és KYNA kölcsönhatásának modellezése SPR szenzorfelületen 
5.5.1. A KYNA szenzorfelületen immobilizált szérum fehérjéken (BSA, HSA)

végbemenö reverzibilis kötödésének kinetikai vizsgálata

5.5.2. A KYNA szenzorfelületen immobilizált szérum fehérjéken (BSA, HSA)

végbemenö reverzibilis kötödésének Van't Hoff analizise

5.5.3. A KYNA szérum fehérjéken (BSA, HSA) végbemenö kötödésének oldatfázisú

kalorimetriás vizsgálata

6. Összefoglalás

.83

7. Summary 86

8. Köszönetnyilvánítás.

9. Irodalomjegyzék 90

10. Publikációs jegyzék 100 


\section{Rövidítések jegyzéke}

AMPA alfa-amino-3-hidroxi-5-metil-4-isoxazol-propionsav

Arg $\quad L$-arginin

ATR (Attenuated Total Reflection): teljes belső visszaverődés

BET Brunauer, Emmett és Teller izotermaegyenlete

BSA (bovine) marha szérum albumin

Cys $\quad L$-cisztein

Cys-Trp L-ciszteinil-triptofán

CPS citrát/foszfát puffer

DLS (Dynamic Light Scattering): dinamikus fényszórás

DNS dezoxiribonukleinsav

ELISA Enzyme-Linked Immunosorbent Assay

GSH L-glutation

HSA humán szérum albumin

IBU ibuprofén

ITC izoterm titrációs kalorimetria

3KYN 3-hidroxi-kinurenin

KYNA kinurénsav

Lys $\quad L$-lizin

LYZ lizozim

MD molekuladinamika (molekulák statisztikus mozgásának szimulációja)

NMDA $\quad N$-metil- $D$-aszpartát

PBS foszfát puffer

QUIN kvinolénsav

RNS ribonukleinsav

OWLS (Optical Waveguide Lightmode Spectroscopy): optikai hullámvezető fénymódus spektroszkópia

QCM (Quartz Crystal Microbalance): kvarckristály mikromérleg

SPR (Surface Plasmon Resonance): felületi plazmon rezonancia

SAXS (Small Angle X-ray Scattering): kisszögü röntgenszórás

TIR (Total Internal Reflection): teljes fényvisszaverődés

VBA (Visual Basic Application): a Microsoft által kifejlesztett programozási nyelv 


\section{Szimbólumok jegyzéke}

\begin{tabular}{|c|c|}
\hline$a_{m}$ & egy molekula felületigénye a határfelületi rétegben \\
\hline$A$ & a QCM kristály aktív felülete \\
\hline$\alpha$ & beesési szög \\
\hline$\beta$ & visszaverődési szög \\
\hline$c$ & a fény vákuumbeli sebessége \\
\hline $\mathrm{c}$ & anyagmennyiség koncentráció (molaritás) \\
\hline$C_{p}$ & állanadó nyomásra vonatkozó hökapacitás \\
\hline $\mathrm{d}$ & rétegvastagság \\
\hline$D_{\max }$ & a párkorrelációs függvény alapján számított legnagyobb átmérő \\
\hline E & elektromos térerősség \\
\hline$E_{0}$ & a síkhullám amplitúdója \\
\hline$E_{p}$ & a foton energiája \\
\hline$E_{s p}$ & a felületi plazmon energiája \\
\hline$\varepsilon_{v}$ & a vákuum dielektromos állandója \\
\hline$\varepsilon_{0}$ & a fényvezető (prizma) dielektromos állandója \\
\hline$\varepsilon_{d}$ & a dielektrikum dielektromos állandója \\
\hline$\varepsilon_{m}$ & a fém dielektromos állandója \\
\hline$f$ & frekvencia \\
\hline$f_{0}$ & a QCM kristály rezonancia frekvenciája, \\
\hline$\Delta f$ & a QCM technikával detektált frekvencia különbség \\
\hline$\Delta G^{0}$ & sztenderd szabadentalpiaváltozás \\
\hline$\Gamma$ & egységnyi felületre vonatkoztatott adszorbeált anyagmennyiség \\
\hline$\Gamma_{m}$ & $\begin{array}{l}\text { a monomolekulás adszorpciós réteg egységnyi felületre vonatkoztatott } \\
\text { adszorbeált anyagmennyisége }\end{array}$ \\
\hline$h$ & Planck-állandó \\
\hline$\hbar$ & redukált Planck-állandó, vagy Dirac-állandó \\
\hline$\Delta H^{0}$ & sztenderd entalpiaváltozás \\
\hline $\boldsymbol{k}$ & hullámszám vektor \\
\hline$k_{a}$ & asszociációs sebességi állandó \\
\hline$k_{d}$ & disszociációs sebességi állandó \\
\hline$k_{o b s}$ & látszólagos sebességi állandó \\
\hline$K_{A}$ & asszociációs folyamat egyensúlyi állandója \\
\hline
\end{tabular}




\begin{tabular}{|c|c|}
\hline$K_{B}$ & adszorpciós folyamat egyensúlyi állandója \\
\hline$k_{p}$ & a foton hullámszáma \\
\hline$k_{s p}$ & a felületi plazmon hullámszáma \\
\hline$k_{x}$ & a hullámszám vektor felülettel párhuzamos komponense \\
\hline$\chi^{2}$ & a statisztikai khi négyzet próba értéke \\
\hline$\lambda$ & hullámhossz \\
\hline$\Delta \lambda$ & az SPR technika által detektált hullámhossz eltolódás \\
\hline$m$ & tömeg \\
\hline$m_{s}$ & egységnyi felületre vonatkoztatott adszorbeált tömeg \\
\hline$\mu_{g}$ & a QCM kristály nyírási modulusa \\
\hline$N_{A}$ & Avogadro állandó \\
\hline$n$ & törésmutató \\
\hline$n_{x}$ & ligandum és receptor közötti anyagmennyiség arány \\
\hline$v$ & a foton frekvenciája \\
\hline$\omega$ & körfrekvencia \\
\hline$Q$ & hőmennyiség \\
\hline$\rho_{q}$ & a QCM kristály sürüsége \\
\hline$r_{p}$ & visszaverődési együttható \\
\hline$R_{p}$ & reflektancia \\
\hline $\mathrm{R}^{2}$ & determinációs együttható \\
\hline$s$ & másodperc \\
\hline$\Delta S^{0}$ & sztenderd entrópiaváltozás \\
\hline$t$ & idő \\
\hline$T$ & abszolút hőmérséklet \\
\hline$\theta$ & felületi borítottság \\
\hline
\end{tabular}




\section{Ábra- és táblázatjegyzék}

1. ábra: A fény törése és visszaverődése eltérő törésmutatójú közegek határfelületén (A) és a fémfelületen gerjesztett felületi plazmonok elektromos térerősség $(E)$ változásának szemléltetése a felülettel párhuzamos (B) és arra merőleges $(\mathrm{C})$ irányban

2. ábra: A fény (szaggatott vonal) és a felületi plazmonok diszperziós görbéjét (A) szemléltetô elvi grafikon valamit a foton és a felületi plazmon csatolás illusztrációja, vákuumból érkező (B) és prizmán áthaladó (C) fény esetében

3. ábra: Monokromatikus fényforrás reflektanciájának számított szögfüggése, prizma/levegő és prizma/arany/levegő (A), valamint prizma/arany/levegő és prizma/arany/polimer/levegő (B) alkotta optikai modellek esetén

4. ábra: Az evaneszcens tér és felületi plazmon gerjesztés létrehozására alkalmas Otto (A)

és Kretschmann (B) névvel jelzett kísérleti elrendezések elvi vázlatai.

5. ábra: A szenzorfelületre integrált mintaterü SPR szenzor felépítésének és a szenzorjel keletkezésének sematikus ábrája

6. ábra: A kinurenin útvonalon keletkező, meghatározó szerepü metabolitok szerkezeti képletei

7. ábra: A SZTE TTIK Fizikai Kémiai és Anyagtudományi Tanszéken müködő kétcsatornás hullámhossz modulált SPR platform fotói

8. ábra: A vizsgálatok során alkalmazott kétcsatornás hullámhossz modulált SPR platform központi egységének vázlata (A: robbantott szerelési terv, B: összeszerelt állapot, $C$ : metszeti kép).

9. ábra: A vizsgálatok során alkalmazott VP-ITC típusú kaloriméter vázlata, valamint a mérési módszert jellemző reprezentatív kalorimetriás görbe $(\mathrm{A})$ és entalpogram (B).

10. ábra: A HSA arany szenzor felületre történő immobilizálása során rögzített jellemző reflektancia görbék (A: mindkét csatornán PBS áramlik, B: a minta csatornában HSA, míg a referencia csatornában PBS áramlik) és szenzorgram $\left(\mathrm{C}: \mathrm{T}=25^{\circ} \mathrm{C}, q_{v}=50 \mu \mathrm{L}\right.$ perc $^{-1}$, $\left.\mathrm{c}_{\mathrm{HSA}}=50 \mu \mathrm{M}\right)$

11. ábra: $B S A(A)$ és $L Y Z(B)$ fehérjék SPR szenzor arany felületére történő immobilizálása során rögzített szenzorgramok $\left(\mathrm{T}=25^{\circ} \mathrm{C}, q_{v}=50 \mu \mathrm{L}\right.$ perc $^{-1}, \mathrm{c}_{\mathrm{BSA}}=30$ $\left.\mu \mathrm{M}, \mathrm{c}_{\mathrm{LYZ}}=60 \mu \mathrm{M}\right)$.

12. ábra: Cys (A), Cys-Trp (B) és GSH (C) molekulák SPR szenzor arany felületére történő immobilizálása során rögzített szenzorgramok $\left(\mathrm{T}=25^{\circ} \mathrm{C}, q_{v}=50 \mu \mathrm{L}\right.$ perc $\left.^{-1}\right) \ldots . . .43$ 13. ábra: Arany felületen kialakuló Cys (A) és a GSH (B) alkotta monomolekulás rétegek kiépülésének QCM technikával történő vizsgálata során meghatározott $\mathrm{f}=\Delta f(\mathrm{c})$ függvények és izotermák

14. ábra: A Cys-Trp MarvinSketch programmal számított minimális- $\left(a_{m}\right.$, min. $)$ és maximális $\left(a_{m, \text { max. }}\right)$ vetületének, és a molekula ezen vetületi síkokhoz viszonyított orientációjának szemléltetése

15. ábra: BSA, HSA és LYS fehérjék oldatfázisú SAXS vizsgálata során rögzített szórásgörbék (A) és a szórásgörbék alapján számított párkorrelációs függvények (B), valamint a SASBDB adatbázisból származó párkorrelációs függvények $(\mathrm{C})$.

16. ábra: A LYZ (felül) és BSA (alul) fehérjék SPR mérése és oldatfázisú SAXS vizsgálata alapján meghatározott geometriai paramétereinek összehasonlítása. 
17. ábra: Neutrális kémhatású pufferbe $(\mathrm{pH}=7,4$; $\mathrm{PBS})$ diszpergált $\mathrm{BSA} / \mathrm{IBU}$ kompozit részecskék méreteloszlás $(\mathrm{A})$ és párkorrelációs $(\mathrm{B})$ görbéi valamit a beszárított mintáról készült reprezentatív TEM felvétel [77]...

18. ábra: A gyógyszerhordozó neutrális és savas közegben kivitelezett SAXS vizsgálatának Kratky reprezentációi (A) és a BSA-IBU mikrokalorimetriás titrálása során rögzített (diszkrét pontok) és modellillesztés útján generált (folytonos vonalak) entalpogramok $\mathrm{pH}=3,0$ és $\mathrm{pH}=7,4$ esetén (B)

19. ábra: BSA-alapú kolloidális gyógyszerhordozó és hatóanyaga (IBU, $\mathrm{c}_{\mathrm{IBU}}=5$ és 20 $\mu \mathrm{M})$ közötti kölcsönhatás SPR-alapú modellezése során neutrális $(\mathrm{A}: \mathrm{pH}=7,4)$ és savas (B: $\mathrm{pH}=3,0)$ közegben rögzített szenzorgramok

20. ábra: $\mathrm{BSA}$ és IBU ( $\mathrm{c}_{\mathrm{IBU}}=5,10,20$ és $\left.30 \mu \mathrm{M} ; \mathrm{pH}=7,4(\mathrm{PBS}) ; q_{v}=50 \mu \mathrm{L} \mathrm{perc}^{-1}\right)$ közötti kölcsönhatás SPR-alapú modellezése során rögzített szenzorgram .... 55

21. ábra: A szenzorgram pszeudo-elsőrendű integrált sebességi egyenlettel történő, nemlineáris paraméterbecslés alapú illesztésének szemléltetése A: tetszőlegesen választott kiindulási paraméterkészlet esetén $\mathrm{B}$ : a nemlineáris becslés által meghatározott paraméterkészlettel

22. ábra: BSA és IBU közötti kölcsönhatás egyideüsített szenzorgramjai (szürke) a szenzorgramok 5.13. egyenlet alapján generált (fekete) modellgörbéivel (A) és a látszólagos sebességi állandók koncentrációfüggése (B)

23. ábra: Az AMPA receptor $N$-terminális doménjének homológia modellje (A), a receptor alegységet mintázó polipetidek modelljei (B) és a GluR1 270-300 feltételezett szenzorfelületi orientációja (C)

24. ábra: Az SPR szenzorfelület GluR1 270-300 polipeptiddel történő funkcionalizálása $\left(\right.$ PEPTID $=30 \mu \mathrm{M} ; \mathrm{pH}=7,4 ; \mathrm{PBS} ; q_{v}=50 \mu \mathrm{L}$ perc $\left.^{-1}\right)$ során rögzített szenzorgram (A) és a funkcionalizált szenzorfelületről készült reprezentatív AFM felvétel (B)

25. ábra: A KYNA oldatfázisból GluR $1_{270-300}$ polipeptiddel funkcionalizált SPR szenzorfelületen végbemenő feldúsulásának koncentráció- és hőmérséklet függő vizsgálata során rögzített szenzorgramok $\left(\mathrm{pH}=7,4\right.$; $\mathrm{PBS} ; q_{v}=50 \mu \mathrm{L}$ perc $\left.^{-1}\right)$

26. ábra: A KYNA GluR1 $270-300$ polipeptiddel funkcionalizált SPR szenzorfelületen végbemenő feldúsulását jellemző adszorpciós izotermák (A) és az izoszer adszorpciós hő $\left(\triangle H^{0}{ }_{a d}\right)$ meghatározását lehetővé tévő lineáris regresszió reprezentatív bemutatása négy eltérö felületi anyagmannyiség arány mellett.

27. ábra: A KYNA GluR1 270-300 polipeptiddel funkcionalizált SPR szenzorfelületi adszorpcióját kísérő $\Delta H^{0}$ ad változása a felületi borítottság (A) és a felületegységre vonatkoztatott GluR1 270-300 és KYNA közötti anyagmennyiség arány (B) függvényében . 64 28. ábra: A KYNA oldatfázisból GluR $1_{270-300}$ polipeptiddel funkcionalizált SPR szenzorfelületen végbemenő feldúsulásának vizsgálata során rögzített szenzorgramok és pszeudo-elsőrendü sebességi egyenlettel (5.14.) illesztett modellgörbéik

29. ábra: A KYNA és GluR1 $270-300$ polipeptid alkotta kötési komplex kialakulását és disszociációját jellemző valós sebességi állandók meghatározása a $k_{o b s}$ koncetrációfüggésének (5.6. egyenlet) lineáris regressziója által

30. ábra: A KYNA GluR1270-300 polipeptiddel funkcionalizált SPR szenzorfelületen végbemenő feldúsulásának vizsgálata során rögzített szenzorgramok együttes értékelését lehető tevő sebességi egyenlet (5.19.) alapján illesztett modellgörbéi. 
31. ábra: A GluR1270-300 polipeptid és KYNA közötti kölcsönhatást jellemzö szenzorgramok diszkrét-(A) és együttes (B) kinetikai modellezése során meghatározott $K_{A}$ értékek van 't Hoff reprezentációja 70

32. ábra: A KYNA GluR1 $231-259$ polipeptiddel funkcionalizált SPR szenzorfelületen, $25^{\circ} \mathrm{C}$ hőmérsékleten végbemenő feldúsulását jellemző szenzorgramok (A) és pszeudo-elsőrendü sebességi egyenlettel (5.14.) illesztett modellgörbéik (B) .74

33. ábra: A KYNA és GluR1 231-259 polipeptid alkotta kötési komplex kialakulását és disszociációját jellemző valós sebességi állandók meghatározása a $k_{o b s}$ koncetrációfüggésének (5.6. egyenlet) lineáris regressziója által .75

34. ábra: A GluR $1_{231-259}$ polipeptid és KYNA alkotta kötési komplex kialakulását jellemző szenzorgramok pszeudo-elsőrendü kinetikai modellezése során meghatározott $K_{A}$ értékek van 't Hoff reprezentációja

35. ábra: SPR szenzor felülethez rögzített BSA és KYNA közötti kölcsönhatás vizsgálata során $25 \mathrm{C}^{\circ}$ hömérsékleteken 1,0 és 10,0 mM közötti analit koncentrációtartományban rögzített szenzorgramok (A) és a pszeudo-elsőrendü sebeségi egyenlettel (5.14.) illesztett modellgörbéik (B)

36. ábra: SPR szenzor felülethez rögzített HSA és KYNA közötti kölcsönhatás vizsgálata során $25 \mathrm{C}^{\circ}$ hömérsékleteken 1,0 és 10,0 mM közötti analit koncentrációtartományban rögzített szenzorgramok (A) és a pszeudo-elsőrendủ sebeségi egyenlettel (5.14.) illesztett modellgörbéik (B)

37. ábra: A KYNA és BSA (A) valamint a KYNA és HSA (B) alkotta kötési komplex kialakulását és disszociációját jellemző valós sebességi állandók meghatározása a $k_{o b s}$ koncentrációfüggésének (5.6. egyenlet) lineáris regressziója által

38. ábra: A KYNA és BSA (A) valamint a KYNA és HSA (B) alkotta kötési komplex kialakulását jellemző szenzorgramok pszeudo-elsőrendü kinetikai modellezése során meghatározott $K_{A}$ értékek van 't Hoff reprezentációja

39. ábra: A BSA/KYNA, HSA/KYNA, GluR $1_{231-259} / \mathrm{KYNA}$ és GluR $1_{270-300} / \mathrm{KYNA}$ kötési komplexek kialakulását jellemző termodinamikai jellemzők összehasonlítása 81

40. ábra: A KYNA és BSA (A) valamint a KYNA és HSA (B) alkotta kötési komplex kialakulását jellemző kalorimetriás görbék (szürke vonal) és entalpogramok (fekete pontok) valamint az entalpogramok 5.23. egyenlettel illesztett modellgörbéi 
1. táblázat: A Cys, Cys-Trp és GSH SPR és QCM által meghatározott adszorpciós-, és MarvinSketch programmal számított geometriai paraméterei

2. táblázat: A BSA, HSA és LYZ fehérjék SPR vizsgálat által meghatározott adszorpciós paraméterei és SAXS alapján számított geometriai jellemzői.

3. táblázat: Az AMPA receptor alegységet modellező polipeptidek SPR vizsgálat által meghatározott adszorpciós paraméterei és számított geometriai jellemzői

4. táblázat: Az AMPA receptor alegység modellek és KYNA kölcsönhatást jellemző entalpia függvények minimumhelyeihez rendelhető entalpia-, borítottság- és felületegységre vonatkoztatott anyagmennyiség arány értékei

5. táblázat: A GluR $1_{270-300}$ polipeptid és KYNA alkotta kötés komplex kialakulását és disszociációját jellemző szenzorgramok diszkrét- és együttes illesztése útján meghatározott sebességi állandók

6. táblázat: A GluR1 270-300 polipeptid és KYNA alkotta kötés komplex kialakulását és disszociációját jellemző szenzorgramok diszkrét- és együttes illesztése útján meghatározott termodinamikai paraméterek

7. táblázat: A GluR1231-259 polipeptid és KYNA alkotta kötés komplex kialakulását jellemző szenzorgramok illesztése útján meghatározott termodinamikai paraméterek 76 8. táblázat: A szérum fehérjék és KYNA alkotta kötés komplex kialakulását jellemző szenzorgramok illesztése útján meghatározott $K_{A}$ paraméterek értékek és ezek alapján számított $\Delta G$ értékek

9. táblázat: A szérum fehérjék és KYNA alkotta kötés komplex kialakulását kísérö $\Delta H^{0}$, $\Delta S^{0}$ és $\Delta C_{p}$ értékek 


\section{Bevezetés}

A receptor-ligandum kölcsönhatások mechanizmusának alaposabb megismerését célzó vizsgálatok meghatározó irányvonalat jelentenek a modernkori kutatásokban és eredményeik kulcsfontosságúak lehetnek a korszerü gyógyszerkutatási fejlesztések eredményességének és költséghatékonyságának tekintetében egyaránt. A fenn említett kölcsönhatások modellezése és kvantitatív jellemzése évtizedeken keresztül radioaktív izotópok által jelölt (,jelzett”) molekulákat alkalmazó, radioanalitikai technikák révén valósult meg, melyek rendkívül hatékony eljárások, de speciális laboratóriumi körülményeket igényelnek. A szorpciós jelenségeket és molekuláris kölcsönhatásokat szilárd/folyadék határfelületen vizsgáló ,jelölésmentes” eljárások, mint a kvarckristály mikromérleg (QCM), az optikai hullámvezető fénymódus (OWLS) valamint a felületi plazmon rezonancia (SPR) spektroszkópia az elmúlt évtizedekben az elektronikai és az informatika háttér rohamos fejlődésével együtt egyre szélesebb körben alkalmazott kutatási módszerré váltak. A viszonylag egyszerü kialakíthatósága és sokrétű alkalmazhatósága miatt a felsorolt technikák közül az SPR eljárás ment át a legintenzívebb fejlődésen; hazai kutatóhelyek tekintetében azonban nem tekinthetö széles körben ismert és alkalmazott technikának. Az SPR spektroszkópia révén a szenzor felületéhez kötött és a szenzor feletti térrészben áramló vegyületek közötti kölcsönhatás kvalitatív és kvantitatív megismerésére adódik lehetőség. A kölcsönható molekulák egyikének szenzorfelülethez történő rögzítése (immobilizálása) révén kvázi kétdimenziós elrendezésben vizsgálható például egy élettani jelentőséggel bíró ligandum receptorhoz vagy receptor modellhez (mimetikumhoz) való kötődése. A mérési technika által szolgáltatott elsődleges kvalitatív információ lehet egy feltételezett specifikus megkötődés létezésének, továbbá reverzibilis vagy irreverzibilis voltának igazolása. Ezen túlmenően a megfelelő kalibráció útján meghatározható az immobilizált partnerhez kötődött vegyület mennyisége, így a kölcsönhatás mennyiségi viszonyai is kvantitatív módon válnak megismerhetővé. Az eljárás valós idejü detektálásának köszönhetöen a kölcsönhatások kinetikai vizsgálata is lehetséges. A korszerü SPR berendezésekben a szenzor felület és a mikrofluidikai felépítmény is termosztálható, így hőmérsékletfüggő sajátságok vizsgálata is könnyedén kivitelezhető.

A dolgozatomban bemutatásra kerülő kutatási munka alapjául az MTA-SZTE Szupramolekuláris és Nanoszerkezetü Anyagok, később az MTA-SZTE Biomimetikus Rendszerek Kutatócsoportban folyó, alfa-amino-3-hidroxi-5-metil-4-isoxazol-propionsav (AMPA) receptort modellező polipeptidek valamint vérszérum fehérjék és neuroaktív 
vegyületek közötti kölcsönhatás, SPR méréstechnikával történő feltérképezésére irányuló vizsgálat sorozat szolgált. A különböző hőmérsékleteken regisztrált, koncentrációfüggő szenzorgramok kinetikai modellel történő illesztését és az egyensúlyi állandók meghatározását követően a van 't Hoff egyenlet alapján számítottam a neuroaktív vegyületként számontartott kinurénsav (KYNA) receptor modelleken és szérum fehérjéken végbemenő kötődéséhez rendelhető entalpia-, entrópia- és állandó nyomásra vonatkozó hőkapacitás-változást. A felsorolt állapotfüggvények ismerete révén sikerült kísérleti úton megerősíteni a KYNA molekuladinamikai szimulációk alapján feltételezett kötési módjának helyességét az AMPA receptort modellező polipeptideken. A kísérletek eredményei bizonyították továbbá a polipeptidek receptor mimetikumként való alkalmazhatóságát és egy KYNA analóg esetében a kémiai szerkezet változásának a kötési módra gyakorolt hatását.

Mindezek mellett munkám során meghatározásra került a szenzor arany felületéhez irreverzibilisen kötődő $L$-cisztein (Cys), és cisztein-tartalmú di- és tripeptidek és fehérjék felületegységre vonatkoztatott adszorbeált anyagmennyisége. A monomolekulás adszorpciós réteget feltételező számítás eredményeként rendelkezésre álló, egy molekulára vonatkoztatott felületigények megismerése hozzájárult a felsorolt molekulák és tetrakloroaurát(III)ionok $\left(\mathrm{AuCl}_{4}^{-}\right)$jelenlétében, vizes közegben spontán képződő, önrendeződő koordinációs polimer struktúrák és fluoreszcens nanoklaszterek kialakulásának magyarázatához.

A méréstechnika lehetőséget adott egy fehérje-alapú, kolloidális gyógyszerhordozó rendszer fejlesztéséhez egy nem-szteroid gyulladáscsökkentő hatóanyag, az ibuprofén (IBU) és a hordozóként alkalmazott marha szérum albumin (BSA) közötti kölcsönhatás szenzorfelületen kivitelezett modellezése által.

A kutatómunka újdonság értéke és ezáltal publikálhatósága abból eredt, hogy bár nagy mennyiségü irodalmi adat áll rendelkezésre makromolekulák közötti kölcsönhatások SPR szenzortechnika általi modellezésének tekintetében, ám elenyésző a makromolekulák és kismolekulás hatóanyagok lehetséges kötődési viszonyait bemutató publikációk száma. A kísérleti adatok feldolgozására a $\mathrm{PhD}$ munkám keretében kidolgozott és alkalmazott kiértékelési módszer nem igényli a szenzorjel kalibrációs eljárással történő további konvertálását, tetszőleges táblázatkezelő szoftver birtokában kivitelezhető és az SPR technikán túl alkalmazható más planáris elrendezésü, a szenzorfelületen feldúsuló anyagmennyiséggel arányos jelet szolgáltató müszer, valós időben rögzített jelének kiértékelésére. 


\section{Irodalmi áttekintés}

\subsection{A felületi plazmon rezonancia jelenségének fizikai magyarázata és a jelenség szenzorikai alkalmazása}

Az elmúlt évtizedek során az SPR spektroszkópia módszere egyre szélesebb teret hódított az élettani jelentőségü kölcsönhatások modellezésben és vizsgálatában. A kvázi kétdimenziós ${ }^{1}$ analitikai eljárás segítségével elsősorban fehérjék közötti kölcsönhatások mennyiségi és minőségi analízise végezhető el. A módszer kiválóan alkalmas a biológiai folyamatok vizsgálatára, felbontásának, érzékenyégének és minimális minta igényének köszönhetően. A korábban e célra alkalmazott vizsgálati módszerek, mint például a QCM méréstechnika, az izoterm titrációs kalorimetria (ITC) vagy az ELISA (enzyme-linked immunosorbent assay) teszt anyagigénye viszonylag nagy lehet és ez rendkívül költségessé teheti a választott rendszer vizsgálatát. Ezekkel szemben az SPR spektroszkópia képes rendkívül alacsony (esetenként $\mu \mathrm{M}$-os vagy akár nM-os) koncentráció tartományban is kimutatni a kérdéses komponens szenzorfelületen végbemenő feldúsulását. A módszer további pozitívuma, hogy a kölcsönhatások valós idejü és jelölőanyag használata nélküli vizsgálatát teszi lehetővé. A leggyakrabban és legszélesebb körben tanulmányozott kölcsönhatások a DNS-DNS, DNS-RNS, DNS-fehérje, lipid-fehérje, fehérje/peptidgyógyszer molekulák között fellépő interakciók.

A módszer alapját képző jelenséget a Johns Hopkins Egyetem kutatója R. M. Wood figyelte meg elsőként, a diffrakciós rácson szórt fény spektrumában megjelenő anomáliával kapcsolatban. Az 1902-ben megjelent cikkében [1] mutatta be, hogy a polarizált fénnyel megvilágított fémalapú diffrakciós rácsról visszaverődő fény spektrumában egy szokatlan sötét és világos sávok alkotta mintázat jelent meg. A kérdéses anomália első magyarázata Lord Rayleigh nevéhez füződik [2], az átfogó kép azonban, amely szerint a jelenség kapcsolatban áll a rács felületén létrejövő elektromágneses felületi hullámok gerjesztésével és a visszavert fény intenzitásának a felületi plazmonok gerjesztése miatti csökkenésével, az 1960-as évekig váratott magára. A felületi plazmonok optikai gerjesztésének vizsgálatában Kretschmann [3] és Otto [4] vizsgálatai szolgáltattak korszakalkotó jelentőségü eredményeket és kialakult a máig elfogadott kép, amely szerint a plazmon rezonancia a fémben lévő vezetési elektronok, elektromágneses tér segítségével gerjesztett hullámszerü

\footnotetext{
${ }^{1}$ A szenzor felület a valóságban két homogén (tömb)fázis közötti véges vastagságú térbeni réteg (határréteg), amelyen belül a fizikai és kémiai sajátságok változnak, de felhasznált matematikai modellekben elhanyagolással élve ezt a térrészt síknak (kétdimenziós határfelületnek) tekintjük.
} 
mozgását jelenti. Térbeli kiterjedése szerinti megkülönböztethető lokális (vagy lokalizált) [5] és felületi [6], illetve térfogati [7] plazmon rezonancia. A felületi plazmon rezonancia (Surface Plasmon Resonance - SPR) a felületi töltéssürüség oszcillációja, mely hatására a fémfelület és a dielektrikum határán a határfelülethez közel erős és attól távolodva exponenciálisan csillapított elektromos erőtér alakul ki [8].

Az SPR-alapú méréstechnika alapját képző fizikai jelenségeket és szenzorikai alkalmazásukat részletes, átfogó és mindemellett könnyen megérthető módon bemutató magyar nyelvü dolgozat tudomásom szerint jelenleg nem áll rendelkezésre. Ennek okán a következő alfejezetekben igyekszem összefoglalni mindazon fizikai törvényszerüségek láncolatát, amelyek az optikai elven müködő plazmonikus szenzor müködését lehetővé teszik.

\subsubsection{Az evaneszcens hullám és az evaneszcens tér}

A jelenség részletes tárgyalásához elsőként a fényvisszaverődésnek az 1. ábra által szemléltetett esetét kell vizsgálni, amikor a fény egy optikailag sürübb közegből egy optikailag ritkább közeg határához érkezik és a beesési szög elég nagy $\left(\alpha_{2}\right)$, így a teljes fénymennyiség visszaverődik a határfelületről.
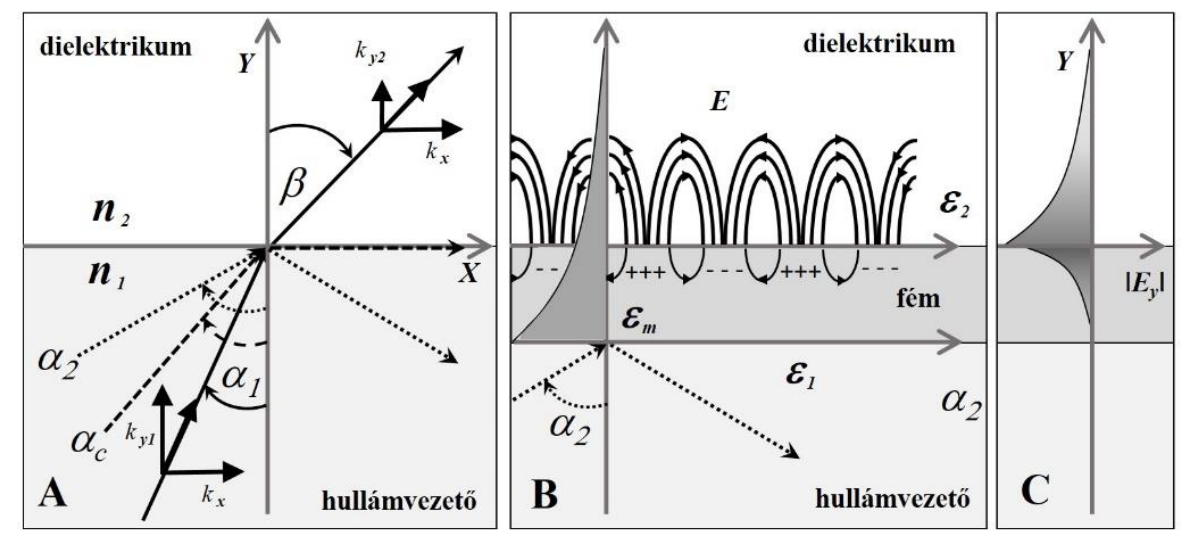

1. ábra: A fény törése és visszaverődése eltérő törésmutatójú közegek határfelületén (A) és a fémfelületen gerjesztett felületi plazmonok elektromos térerősség $(E)$ változásának szemléltetése a felülettel párhuzamos (B) és arra merőleges $(C)$ irányban

A leírt speciális eset (az 1. ábra A részén $\alpha_{2}$-vel szemléltetett eset) a teljes fényvisszaverődés (totálreflexió) optikai jelensége, amelyet gyakran az angol betüszót használva a TIR (total internal reflection) rövidítéssel jelölnek. A jelenség nyújtotta lehetőségeket kiaknázó analitikai eszközöket pedig a teljes belső visszaverődésen alapuló vagy ATR (attenuated 
total reflection) szenzoroknak nevezik [9]. Az ATR szenzorok esetében a visszaverödő fény intenzitás-változásának mérésén keresztül lehetséges a szenzor körüli kémiai környezet megváltozásának érzékelése [10]. A megfelelő kísérleti elrendezésben tehát a fényvezetőn végig haladó fény visszaverődik a fényvezető felületéről, miközben energiájának egy része kicsatolódik a fényvezetőt határoló közegbe. Ilyenkor a határfelületen átlépő fény az úgynevezett evaneszcens hullám, amelynek behatolási mélysége mindössze néhány száz nanométer és intenzitása a behatolási mélységgel exponenciálisan csökken [11]. Az evaneszcens tér intenzitásának $(I)$ a felszíntől merőlegesen mért távolság ( $y$ ) függvényében bekövetkező csökkenése leírható a 2.1. összefüggéssel:

$$
I(y)=I_{0} e^{-y / d}
$$

ahol $I(Y)$ a közeghatártól merőlegesen mérhető intenzitás, $I_{0}$ a beeső fény közeghatáron $(Y=$ 0 ) mérhető intenzitása és $d$ a behatolási mélység. A behatolási mélység a 2.2. egyenlet szerint a beeső fénysugár hullámhosszával $(\lambda)$ arányos és függvénye továbbá a beesési szögnek $(\alpha)$ és az érintkező közegek törésmutatójának ( $n_{1}$ és $\left.n_{2}\right)$.

$$
d=\frac{\lambda}{2 \pi \sqrt{n_{1}^{2} \sin ^{2} \alpha-n_{2}^{2}}}
$$

A 2.2. egyenlet alapján könnyen belátható, hogy a behatolási mélység nagyságrendileg a beeső fény hullámhosszának a felére becsülhető. Az $n_{l}$ törésmutatójú hullámvezető felületét a behatolási mélységnél kisebb vastagságú fém réteggel bevonva a fémben lévő felületi plazmonok az elektromágneses sugárzás hatására gerjeszthetővé válnak. Ezek a felületi plazmonok (plazmon-polaritonok) a fém felületén gerjesztett elektronsürüség oszcillációjából és a hozzá csatolt, a felületre merőleges elektromos vektorú elektromágneses térből tevődnek össze, ahogy azt az 1. ábra $\mathbf{B}$ része sematikus módon szemlélteti [12].

A jelenségről alkotott kvantitatív kép kialakításához azonban elsőként az evaneszcens hullám matematikai modelljét kell definiálni és felhasználni. Az $n_{l}$ törésmutatóval jellemezhető (transzparens, homogén és izotróp) közegben az elektromágneses tér adott frekvenciával jellemezhető (monokromatikus) síkhullámok összegére bontható [13]. Az elektromos térerősség $(E)$ egy ilyen síkhullámban, $t$ időben és $\boldsymbol{r}$ helyvektorú (a fényforrástól távoli) pontban matematikailag az erőtér a 2.3. összefüggéssel írható le.

$$
E=E_{0} \exp (j \omega t-j \boldsymbol{k} \cdot \boldsymbol{r})=E_{0}\left(j \omega t-j k_{x} x-j k_{y} y-j k_{z} z\right)
$$


Az $E_{0}$ jelöli a síkhullám amplitúdóját, $\omega$ a körfrekvenciát, $\boldsymbol{k}$ a hullámszámvektort ${ }^{2}$, amelyet gyakran rövidítve hullámvektorként említünk és $j$ értéke: $j=\sqrt{-1}$, vagyis az egyenlet komplex exponenciálisa haladó hullámot definiál. A hullám terjedési irányával párhuzamos hullámvektor nagyságát a 2.4. kifejezés határozza meg,

$$
k=\sqrt{k_{x}^{2}+k_{y}^{2}+k_{z}^{2}}=n \frac{2 \pi}{c}=n \frac{\omega}{\lambda}
$$

amelyben $\lambda$ és $c$ jelenti a vákuumbeli hullámhosszat és a haladási sebességet. Ezután tekintsünk az 1. ábra A része által szemléltetett esetet, amely során a hullám visszaverödik az eltérő törésmutatójú közegek alkotta határfelületről. A vázolt modellben tetszőlegesen kiválasztható olyan fénysugár, amelyre a $k_{z}=0$ feltétel teljesül, ezáltal kétdimenziósra egyszerüsödik a vizsgált rendszer és alkalmazható a Snellius-Descartes-törvény (2.5. egyenlet):

$$
n_{1} \sin \alpha=n_{2} \sin \beta
$$

és a törvénnyel analóg 2.6. összefüggés.

$$
k_{x_{1}}=k_{x_{1}} \equiv k_{x}
$$

A 2.4. és a 2.6. egyenletek kombinálásával, az $n_{2}$ törésmutatóval jellemezhető közegre is kifejezhető a hullámvektor felületre merőleges komponensét $\left(k_{y_{2}}\right)$ meghatározó összefüggés, amely a 2.7. egyenlet formájában írható fel.

$$
k_{y_{2}}^{2}=n_{1}^{2}\left(\frac{2 \pi}{\lambda}\right)^{2}\left(\frac{n_{2}^{2}}{n_{1}^{2}}-\sin ^{2} \alpha\right)
$$

Amennyiben teljesülnek az $n_{1}>n_{2}$ illetve $\sin \alpha>n_{1} / n_{2}$ relációk, az egyenlet jobb oldala negatívvá válik, következésképp a hullámvektor felületre merőleges komponense tisztán imagináriussá válik. Mindezek tükrében megállapítható, hogy 2-es indexszel jelölt közegben kizárólag a közeghatárral párhuzamosan haladó hullám jelenik meg, a 2.8. kifejezés értelmében

$$
E_{2}=E_{0} e^{-\kappa_{y_{2}} y} \exp \left(j \omega t-j k_{x} x\right)
$$

a felülettől távolodva exponenciálisan csökkenő térerősséggel, amelyből az evaneszcens ${ }^{3}$ tér elnevezés származik [14]. Továbbá az is belátható, hogy az exponenciális csökkenés és a

\footnotetext{
${ }^{2}$ A hullámszám $(k)$ értéke a hosszegységre jutó hullámok számának $2 \pi$-szerese, amelyet a $k=\frac{2 \pi v}{c}=\frac{\omega}{c}$ összefüggés alapján a hullámszámvektor abszolút értékét értelmeztük.

${ }^{3}$ Az evaneszcens kifejezés angol megfelelője (evanescent) a latin „,ex” és „,vanescere” ötvözéséből ered, melléknévként fordítva a jelentése végtelen kicsibe átmenő.
} 
behatolási mélység révén a 2-es indexszel jelölt közegben kizárólag a határfelület közelében bekövetkező törésmutató változás fogja befolyásolni az elektromágneses erőteret. Amennyiben az 1-es (hullámvezető) és 2-es (dielektrikum) indexszel jelölt közeg határára egy az elsődleges evaneszcens tér kiterjedésénél vékonyabb fémréteg kerül (1. ábra $\mathbf{B}$ része), a fémréteg és a dielektrikum határfelületén megfelelő körülmények esetén egy újabb evaneszcens tér fog létrejönni (1.ábra $\mathbf{C}$ része). Az elsődleges evaneszcens által gerjesztett, fémfelületen lévő vezetési elektronok kollektív mozgásához kapcsolódó elektronsürüséghullámok a fém és a dielektrikum alkotta határfelületen, a határfelülethez kötődve terjednek, a fémfelületre merőleges irányban pedig a plazmonok elektromos tere exponenciálisan csökken.

\subsubsection{Diszperziós összefüggések és a felületi plazmonok gerjesztése}

Egy fém felület esetén az evaneszcens tér létrehozásának tipikus módja a felületi plazmonok gerjesztése lézerfény segítségével. A felületi plazmonok energiája $\left(E_{s p}\right)$ ugyan megegyezhet a gerjesztő fény fotonjainak energiájával $\left(E_{p}\right)$, hullámszáma ${ }^{4}\left(k_{s p}\right)$ azonban nagyobb a fotonok hullámszámánál $\left(k_{p}\right)$. Mindez annak a következménye, hogy a felületi plazmonok diszperziós görbéje (frekvenciájuk hullámszám függvénye) eltér a fény diszperziós összefüggésétől (amely lényegében a fény vákuumbeli sebessége), ahogy azt a

2. ábra A része szemlélteti.
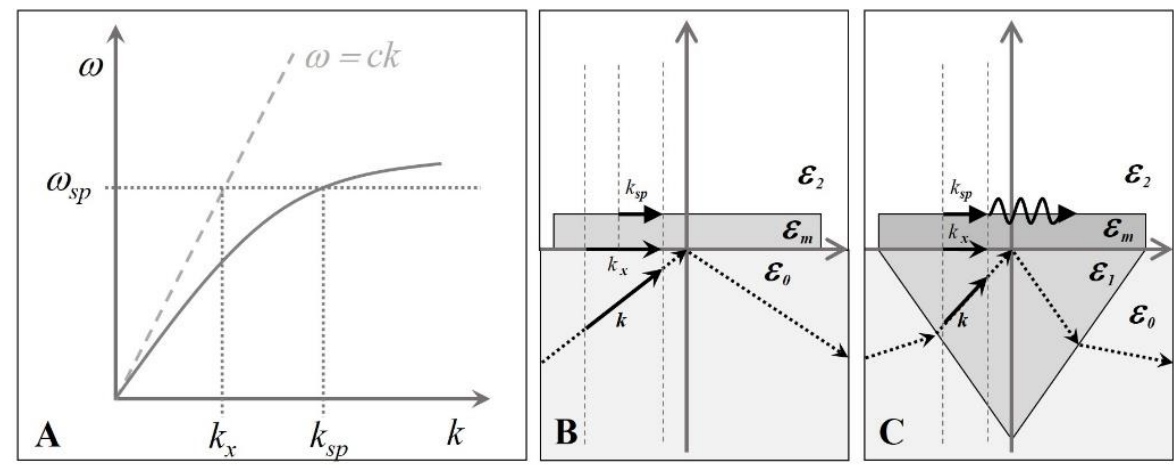

2. ábra: A fény (szaggatott vonal) és a felületi plazmonok diszperziós görbéjét (A) szemléltető elvi grafikon valamit a foton és a felületi plazmon csatolás illusztrációja, vákuumból érkező (B) és prizmán áthaladó (C) fény esetében

Adott energiánál tehát a fény hullámszáma (a gerjesztő foton impulzusa) nagyobb, mint a megfelelö felületi plazmon hullámszáma [15]. Az energia- és impulzus megmaradás

\footnotetext{
${ }^{4}$ A hullámszámvektor abszolút értéke.
} 
törvényének viszont a foton és a felületi plazmon csatolás esetében is érvényesülni kell, ezáltal a fénnyel történő gerjesztéséhez a hiányzó impulzus pótlására van szükség. Mindezek bizonyításához azonban elsőként a felületi plazmonok diszperziós összefüggését szükséges meghatározni. Bármely tetszőleges két közeg alkotta határfelület esetén a visszaverődési együtthatóra $\left(r_{p}\right)$ vonatkozó összefüggést a Maxwell-egyenletek síkhullám-megoldásának felhasználásával levezethető Fresnel-féle formulák határozzák meg [16,17]. A beesési síkkal párhuzamos (p-) polarizáció esetén értelmezett Fresnel-egyenlet alapján a visszaverődési együttható beesési- és visszaverődési szögtől való függését a 2.9. összefüggés írja le,

$$
r_{p}=\frac{E_{i}}{E_{r}}=\left|r_{p}\right| e^{j \varphi}=\left|\frac{\tan (\alpha-\beta)}{\tan (\alpha+\beta)}\right| e^{j \varphi}
$$

ahol $E_{i}$ és $E_{r}$ a beeső- és visszaverődő elektromos térerősség az 1. ábra $\mathbf{A}$ részén vázolt $\alpha$ és $\beta$ szögek esetében [18]. Természetesen az $\alpha$ és $\beta$ szögek kapcsolatát továbbra is a SnelliusDescartes-törvény határozza meg és a visszaverő mező fázisváltozása $(\varphi)$ az érintett anyagok törésmutatójának is függvénye. Amennyiben $\alpha$ és $\beta$ szögek összege $90^{\circ}(\pi / 2)^{5}$, akkor a nevezö értéke végtelen nagy lesz, így a visszavert intenzitás aránya, a reflektancia ( $R_{p}=$ $\left|r_{p}\right|^{2}$ ) nullává válik. A másik speciális eset akkor fordul elö, amikor az $\alpha$ és $\beta$ szögek különbsége $90^{\circ}$. Ekkor a reflektancia végtelen nagyságú, véges nagyságú beeső- $\left(E_{i}\right)$ és rendkívül kicsiny $\left(E_{r}\right)$ visszaverődő térerősség mellett, ami a rezonancia megfelelője. Az $\alpha$ és $\beta$ szögek kapcsolata alapján levezethető a diszperziós összefüggés, ha $\alpha-\beta=\pi / 2$ akkor $\cos \alpha=-\sin \beta$ és $\tan \alpha=k_{1_{x}} / k_{1 y}=-n_{2} / n_{1}$. A hullámvektor $\left(\boldsymbol{k}=\left(k_{x}, k_{y}\right)\right)$ komponensei a 2.10. és a 2.11. egyenletekkel, az alábbi formában fejezhetők ki.

$$
\begin{gathered}
k_{x}^{2}=k_{1}^{2}-k_{y_{1}}^{2}=k_{1}^{2}-k_{x}^{2} \frac{\varepsilon_{1}}{\varepsilon_{2}} \\
k_{x}=\frac{\omega}{c} \sqrt{\frac{\varepsilon_{1} \varepsilon_{2}}{\varepsilon_{1}+\varepsilon_{2}}} \quad \text { és } \quad k_{y_{i}}=\frac{\omega}{c} \sqrt{\frac{\varepsilon_{i}^{2}}{\varepsilon_{1}+\varepsilon_{2}}}
\end{gathered}
$$

Amelyekben $\varepsilon_{1}$ és $\varepsilon_{2}$ az 1-es (hullámvezető) és 2-es (dielektrikum) indexszel jelölt közegek dielektromos állandója (permittivitása ${ }^{6}$ ) és i értéke 1 vagy 2 . Amennyiben a hullámvezető és dielektrikum alkotta határfelület helyett hullámvezetö/fém határfelületet vizsgálunk, figyelembe kell venni, hogy a fémben lévő szabad elektronok (a vezetési sávban lévő elektronjai) a külső tér hatására elmozdulhatnak és a fény kötött elektronok is gerjesztett

\footnotetext{
${ }^{5}$ Ezt a speciális helyzetet nevezik Brewster szögnek, amely esetén a visszavert és a megtört sugarak merőlegesek egymásra, az ennek megfelelő beesési szögnél a p-polarizált fény nem verődik vissza. ${ }^{6}$ A permittivitás és a törésmutató kapcsolatát, az egységnyi relatív permeabilitású (nem mágneses) anyagok esetében az $n=\sqrt{\varepsilon}$ összefüggés határozza meg.
} 
állapotba kerülhetnek fotonok elnyelése révén. Makroszkopikus fémréteg esetében és a fém rácsállandójánál nagyobb hullámhosszú gerjesztő sugárzás mellett a fém dielektromos függvénye a frekvenciafüggő komplex dielektromos állandójával $\varepsilon_{m}(\omega)$ a 2.12. összefüggés szerint írható le.

$$
\varepsilon_{m}(\omega)=1-\frac{\omega_{p}^{2}}{\omega^{2}+i \gamma \omega}
$$

A frekvenciafüggő viselkedését egyrészt az határozza meg, hogy a fémen belül a vezetési sávban lévő elektronok a külső tér hatására szabadon elmozdulhatnak, másrészt a fém sávszerkezetének megfelelően a kötött elektronok a fotonok elnyelése révén gerjesztett állapotba kerülhetnek $[19,20]$. A fémek $\varepsilon_{m}(\omega)$ függvényének meghatározására az itt nem részletezett Drude- és Lorentz modellek használhatók, melyek bár klasszikusan az egy elektron probléma megoldását szolgáltatják, mégis helyesen írják le a fémek elektromos vezetőképességét. A látható fénynél alacsonyabb gerjesztő frekvencia esetén az elektromágneses térnek csak elhanyagolható része hatol be a fémbe ezáltal ebben a gerjesztési tartományban a fémek vezetőként jellemezhetők. A látható tartományban az elektromágneses tér mélyebbre hatol a fémben, így a gerjesztő fotonok energiavesztése is jelentősebb lehet, míg az ultraibolya tartományán és azon felül a fém szigetelőként viselkedik, az elektromágneses tér ekkor a fém sávszerkezetnek megfelelően, csillapítva terjed a fémben.

Amennyiben a 2.12. összefüggésbe szereplő plazma frekvencia ${ }^{7}\left(\omega_{p}\right)$ meghaladja a gerjesztő frekvenciát a fém komplex dielektromos állandójának valós része negatív értéket vehet fel [16]. Emellett a fém permittivitása nagyobb, mint a hullámvezető permittivitásának ellentettje $\left(\varepsilon_{m}>-\varepsilon_{1}\right)$, így a hullámvektor határfelületre meröleges komponense $\left(k_{y i}\right)$ imagináriussá válik és csupán a párhuzamos komponens $\left(k_{x}\right)$ marad valós. Ekkor tehát az elektromágneses hullám, kizárólag a határfelület mentén terjed, evaneszcens tere a határfelület mindkét oldalára kiterjed és a behatolási mélység a fém tömbfázisa felé egy nagyságrenddel kisebb, mint az ellentétes irányba ${ }^{8}$, ahogy azt az 1. ábra $\mathbf{C}$ része szemlélteti.

A fentiek során vázolt elrendezés egyben teljesíti a felületi plazmon rezonancia kialakulásának azon feltételét, hogy a gerjesztő elektromágneses sugárzás (fény), a vákuum törésmutatójánál nagyobb törésmutatójú hullámvezetőn (pl. üveg prizmán) keresztül

\footnotetext{
${ }^{7}$ A szabad elektrongáz plazma frekvenciája $\omega_{p}=n e^{2} / \varepsilon_{0} m_{e}$, ahol $n$ a szabad elektron sürüség, $e$ az elektron töltése, $\varepsilon_{0}$ a vákuum permittivitása és $m_{e}$ az elektron tömege.

${ }^{8} \mathrm{Az}$ arany és víz alkotta határfelületen, $700 \mathrm{~nm}$ gerjesztő $\lambda$ mellett az 1.2.3. egyenlet alapján a behatolási mélység $\left(1 / k_{y i}\right)$ értéke számítható az arany $(\varepsilon \approx-16,00)$ és víz $(\varepsilon \approx-1,77)$ permittivitásának ismeretében, ekkor a tömbi arany fázis irányába: $1 / k_{y, \text { arany }}=26 \mathrm{~nm}$, míg a levegő irányába: $1 / k_{y, \text { levegó }}=238 \mathrm{~nm}$.
} 
haladva verődjön vissza a fém és a hullámvezető alkotta határfelületről. Ekkor ugyanis a megfelelő szögben $\left(\alpha_{2}\right)$ becsatolt fény impulzusának a felülettel párhuzamos komponense $\left(k_{x}\right)$ megegyezhet az azonos energiájú felületi plazmon impulzusával ${ }^{9}\left(k_{s p}\right)$ és rezonancia jellegü erős csatolás (felületi plazmon gerjesztés) jöhet létre [21]. A gerjesztés létrejöttének fizikai feltételét igyekszik a 2. ábra $\mathbf{B}$ és $\mathbf{C}$ része geometriai módon szemléltetni. A megfelelő kísérleti elrendezésen túl, a gerjesztő fényforrás tekintetében szerencsés, ha az monokromatikus és a felület síkjában polarizált ( $\mathrm{p}$-polarizált), ugyanis a nem p-polarizált elektromágneses hullám nem járul hozzá a felületi plazmon gerjesztéshez, csupán a visszavert fény háttérintenzitását növeli [22].

Mindezek definiálása után bizonyítható a jelenség analitikai alkalmazhatósága a következő gondolatkísérlet alapján. Tegyük fel, hogy a szenzor prizma/arany/víz elrendezést követ és víz tömbi fázisában oldott molekulák ${ }^{10}$ egy része az arany felülethez való affinitása révén, kicserélődési folyamatban vízmolekulák helyét foglalja el az arany/víz határfelületen. Mivel minden kétséget kizáró, hogy a víz és az oldott anyag dielektromos állandója eltérö $\left(\varepsilon_{\text {víz }} \neq \varepsilon_{\text {oldott anyag }}\right)$ az is belátható, hogy a felület közelében kialakuló átlagos dielektromos állandó értéke meg fog változni az oldott anyag határfelületen (ezzel együtt az evaneszcens térben) való feldúsulása miatt. A 2.11. egyenlet szerint pedig a hullámvektor felülettel párhuzamos komponense $\left(k_{x}\right)$ a fémfelület feletti (evaneszcens) térrész dielektromos állandójának $\left(\varepsilon_{2}\right)$ is függvénye. A 2.9. és 2.10. egyenletek magukban foglalják a határfelületről visszaverődő fény intenzitásának szögfüggését és az érintett anyagok törésmutatójától való függését. Az említett függvénykapcsolatok garantálják, hogy a megfelelő kísérleti elrendezés kialakítása révén létrehozható olyan szenzor, amely a visszaverődő fény intenzitásváltozásának mérése alapján képes valós időben jelezni a szenzorfelület feletti térrész kémiai összetételének változását.

\subsubsection{A felületi plazmonok gerjesztésének következménye}

$\mathrm{Az}$ előző fejezet végén vázolt függvénykapcsolatok lehetőséget nyújtanak alkalmasan megválasztott optikai elrendezés esetén a visszavert fényintenzitás, felületi plazmon rezonancia gerjesztés okozta módosulásának modellezésére. A számítások

\footnotetext{
${ }^{9}$ A részecske-hullám kettősséget kifejező $p=\frac{h}{\lambda}=\frac{h v}{c}=\frac{h \omega}{2 \pi c}=\hbar \frac{\omega}{c}=\hbar k$ összefüggés alapján, elhanyagolással élve azonosnak tekintjük a foton és felületi plazmon hullámszámát $(k)$ és impulzusát $(p)$.

${ }^{10} \mathrm{Ez}$ a vizes oldat tölti be a felületi plazmonok diszperziós összefüggésének levezetése során definiált 2-es közeg, a dielektrikum helyét.
} 
tetszőleges optikai modellre történő alkalmazását, a reflektancia görbék megjelenítését és azok adatpárjainak mentését teszi lehetővé a szabad felhasználású Winspall ${ }^{11}$ nevü program [23-25]. A szoftver a Fresnel egyenlet (2.9.) alapján, monokromatikus fényforrást feltételezve képes a reflektancia szögfüggésének szimulációjára tetszőleges rétegvastagságú és anyagi minőségü optikai rétegmodellek esetén [24]. Az 1. ábra A részén vázolt elrendezésnek megfelelő optikai modell esetében (prizma: $\varepsilon^{\prime}=2,29 ; \varepsilon^{\prime \prime}=0,00$ / levegö: $d=$ $\left.\infty \mathrm{nm}, \varepsilon^{\prime}=1,00 ; \varepsilon^{\prime \prime}=0,00\right)^{12}, 700 \mathrm{~nm}$ hullámhosszú gerjesztő forrást választva, a számított reflektancia görbén értelemszerüen nem jelenik meg a felületi plazmonok gerjesztéséhez rendelhető reflektancia minimum. A prizma és levegő alkotta modell esetén (a 3. ábra A részén szaggatott vonallal jelzett görbe) ekkor, alacsony szögtartományban a beeső fény lényegében visszaverődés nélkül halad át a határfelületen, majd 30 és $39^{\circ}$ között rohamosan növekszik visszavert fény aránya és $39^{\circ}$ felett elérjük a teljes visszaverődés tartományát. A teljes belső visszaverődés határának megfelelő szög $\left(\alpha_{c}=39^{\circ}\right)$ értéke, kizárólag a két végtelennek tekintett közeg dielektromos állandójának (prizmának és a dielektrikumnak, utóbbi jellemzően levegő vagy víz) különbségétől függ.
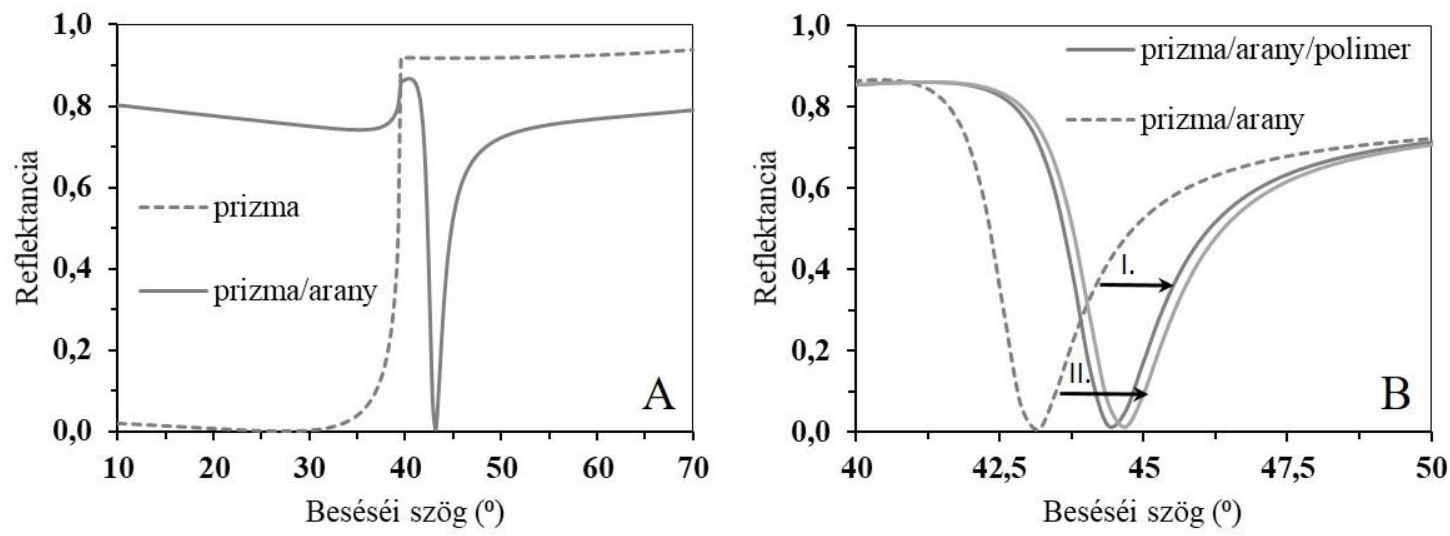

3. ábra: Monokromatikus fényforrás reflektanciájának számított szögfüggése, prizma/levegö és prizma/arany/levegö (A), valamint prizma/arany/levegő és prizma/arany/polimer/levegő (B) alkotta optikai modellek esetén

Az optikai modellt a 2. ábra $\mathbf{C}$ részének megfelelően módosítva, a prizma felületén „kialakított” $50 \mathrm{~nm}$ vastagságú fémréteg révén megjelenik a modellben a komplex

\footnotetext{
${ }^{11} \mathrm{http}: / /$ res-tec.de/downloads.html

${ }^{12}$ A hullámvezető közeg szerepét az üveg prizma tölti be. A közegek dielektromos állandójának $(\varepsilon)$ valós és képzetes részét $\varepsilon$ 'és $\varepsilon "$, a rétegvastagságot pedig $d$ jelöli.
} 
dielektromos állandójú (arany: $\left.d=50 \mathrm{~nm} \varepsilon^{\prime}=-12,45 ; \varepsilon "=1,30\right)^{13}$ komponens, amely komplex állandójának valós tagja negatív és nagyobb abszolút értékü, mint a képzetes rész. A reflektancia görbén ekkor az alacsony szögtartományban az arany fényvisszaverö tulajdonsága révén erős reflektancia növekedés tapasztalható, mindemellett a kritikus szög feletti szögtartományban a reflektancia görbe éles minimumon megy át (3. ábra A részén folytonos vonal), ami annak köszönhető, hogy ekkor a beeső fény teljes intenzitása a felületi plazmonok gerjesztésére fordítódik, így $43^{\circ}$-os beesési szög esetén nem mérhető visszaverődő fényintenzitás. A görbe, ekkor a tipikus „funkcionalizálatlan szenzorfelület” optikai tulajdonságait írja le, amely a további SPR spektroszkópiai alapját képezi.

A jelenség és a vázolt kísérleti elrendezés analitikai alkalmazhatóságát szemlélteti a 3. ábra B része, ahol modellezett szenzor arany felületét teoretikus, $10 \mathrm{~nm}$ vastagságú rétegben, polietilén-glikol (PEG) $10 \mathrm{~m} / \mathrm{m} \%$, vizes oldat borítja (I. eset: $d=10 \mathrm{~nm} \varepsilon^{\prime}=1,85$; $\left.\varepsilon^{\prime \prime}=0,00\right)$ [26]. A polimer megjelenésével (az evaneszcens térben bekövetkező változás, amely a térrész dielektromos állandójának értékét érinti) a szoftver által készített reflektancia görbén megjelenő minimum a nagyobb szögtartományba tolódik. A 3. ábra B részén személtetett II. esetben a minimumhely eltolódásának mértéke a polimer koncentrációjának kétszerese következtében nagyobb mértékü, mint az I. esetben. A szenzorfelület feletti evaneszcens térben bekövetkező kémiai összetétel változás tehát az átlagos dielektromos állandó (II. eset: $d=10 \mathrm{~nm} \varepsilon^{\prime}=1,95 ; \varepsilon ”=0,00$ ) értékének változását eredményezi, amely megváltoztatja a rezonancia feltételt és ezáltal a reflektancia függvény minimum helyét.

A vázolt függvénykapcsolatok kvantitatív és kompakt megfogalmazása a gerjesztő fény hullámvektorának felülettel párhuzamos komponensét meghatározó 2.13. kifejezés

$$
k_{x}=\frac{\omega}{c} n_{p} \alpha=\frac{2 \pi}{\lambda} n_{p} \alpha
$$

és a felületi plazmon hullámvektorát definiáló 2.14. összefüggés

$$
k_{s p}=\frac{\omega}{c} \sqrt{\frac{\varepsilon_{m} \varepsilon_{d}}{\varepsilon_{m}+\varepsilon_{d}}}
$$

egyetlen, a 2.15. formában felírható egyenletben történő összegzése révén adható meg.

$$
\frac{2 \pi}{\lambda} n_{p} \alpha=\frac{\omega}{c} \sqrt{\frac{\varepsilon_{m} \varepsilon_{d}}{\varepsilon_{m}+\varepsilon_{d}}}
$$

\footnotetext{
${ }^{13} \mathrm{~A} \varepsilon$ képzetes része határozza meg, hogy milyen sebességgel transzformálódik hővé a plazmon rezonancia energiája. Arany és ezüst (melyekre teljesülnek az $\varepsilon^{\prime}<0$ és $\left|\varepsilon^{\prime}\right|>\varepsilon^{\prime}$,feltételek) fénnyel történő gerjesztése a reflektancia minimumban közel 100\%-os a hatásfokú, így éles rezonancia görbe jelenik meg.
} 
A rezonancia feltétel $\left(k_{x}=k_{s p}\right)$ függvénykapcsolatai ezáltal a 2.15. egyenletbe tömöríthetők, ahol $\varepsilon_{\mathrm{d}}$ és $\varepsilon_{\mathrm{m}}$ dielektrikum és a fém permittivitása, $n_{p}$ a prizma törésmutatója, $\lambda$ a gerjesztő fény hullámhossza és $\alpha$ a beesési szöge. A felsorolt paraméterek kapcsolata révén adódik lehetőség a fentiekben vázolt, úgynevezett szögmodulált mérési eljárás kivitelezésére, amely során állandó $\varepsilon_{\mathrm{m}}, \varepsilon_{\mathrm{d}}, n_{p}$ és $\lambda$ értékek mellett, $\alpha$ változtatásával határozható meg a visszavert fényintenzitás szögfüggése, majd $\varepsilon_{\mathrm{d}}$ változásának szögfüggésre gyakorolt hatása. A felsorolt fizikai paraméterek függvénykapcsolata lehetőséget nyújt ezen felül az úgynevezett hullámhossz modulált mérés kivitelezésére is, amely során $\varepsilon_{\mathrm{m}}, \varepsilon_{\mathrm{d}}, n_{p}$ és $\alpha$ értékének állandósága mellett, $\lambda$ változtatásával (polikromatikus gerjesztő fény révén) határozható meg a visszavert fényintenzitás hullámhossz függése ${ }^{14}$.

\subsubsection{Az SPR szenzorok alkalmazása a kémiai analizisben}

A szenzorikai alkalmazások esetében a legelterjedtebb kísérleti megvalósítás az Otto, illetve a Kretschmann nevével azonosított elrendezés (4. ábra), amelyek esetén a gerjesztéshez alkalmazott polarizált fényforrás prizmán keresztül haladva verődik vissza a határfelületről és a visszavert nyaláb intenzitásának változása mérhető egy megfelelő detektor segítségével. Az Otto konfiguráció esetén (4. ábra A része) a dielektrikum a prizma és a fémréteg között helyezkedik el, míg a Kretschmann elrendezés esetén (4. ábra B része) a fémréteg közvetlenül az prizmához kapcsolódik (annak felületén kerül kialakításra), így fémfelületen közvetlenül kialakítható a mintatér (mintakamra).
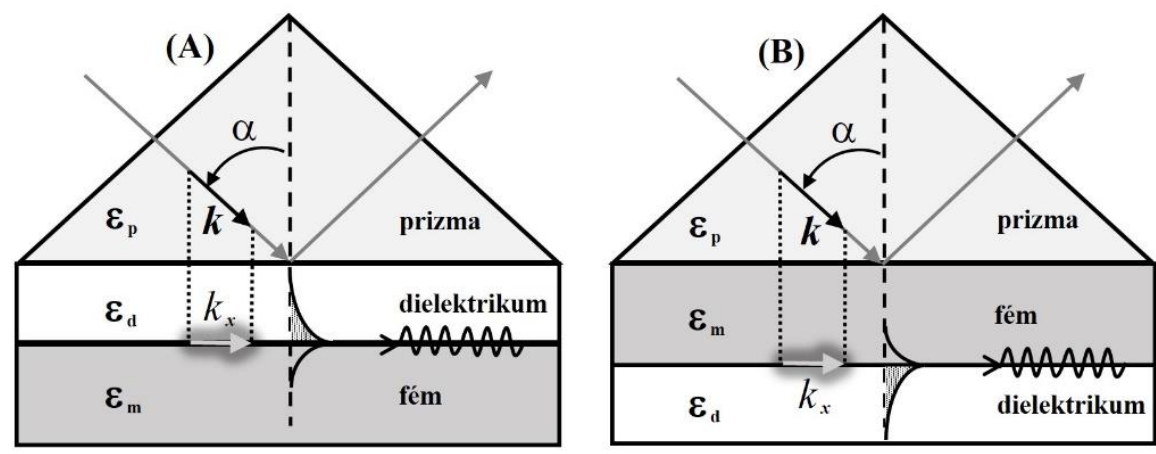

4. ábra: Az evaneszcens tér és felületi plazmon gerjesztés létrehozására alkalmas Otto (A) és Kretschmann (B) névvel jelzett kísérleti elrendezések elvi vázlatai

\footnotetext{
${ }^{14}$ A hullámhossz modulált mérési eljárás ad magyarázatot arra, hogy miért terjedhetett el a „felületi plazmon rezonancia spektroszkópia" kifejezés, hiszen ebben az esetben az elsődleges jel valóban egy intenzitás jellegü mennyiség energia szerinti eloszlását, vagyis spektrumát foglalja magában.
} 
A Kretschmann elrendezés előnye, hogy a fémréteg hordozóra való felvitele révén cserélhető a szenzor aktív felülete, a tipikusan ezüst vagy arany bevonattal ellátott szenzor chip nemesfém felülete, így a szenzor egyéb felépítményeitől elkülönítve, kémiailag módosítható. A minta szenzorfelületre juttatását biztosító kamra vagy áramlásos cella közvetlenül a szenzor chip felületéhez kapcsolódik, de különálló modulra történő integrálása révén a szenzor aktív felületét alkotó fémréteg a hordozóval együtt a kívánt mérésnek megfelelően cserélhetővé válik. A korszerü berendezések esetében a tipikusan arany filmmel ellátott szenzor chip a gyártó által garantált kémiai összetételü és minőségü funkcionalizált réteggel együtt vásárolható meg. Ezzel együtt a legtöbb kereskedelmi forgalomban elérhető berendezés továbbra is fenntartja az arany bevonatú szenzorfelület módosításának későbbi lehetőségét, így a felület funkcionalizálása során bekövetkező változások is követhetők.

A mérési módszer analitikai célú alkalmazását bemutató első publikáció által ismertetett müszer esetében a Kretschmann elrendezésű és ezüst bevonatú szenzor funkcionalizált felületét egy szilikon olaj alkotta réteg biztosította [27]. Az 1982-ben megjelent cikk lényegében egy felületi plazmon rezonancia alapú gázszenzor müködését mutatja be, amely a felületére vezetett nitrogén gáz halotán ${ }^{15}$ tartalmát hívatott meghatározni a szilikon olajba oldódó fluorozott szén-hidrogén miatti lokális törésmutató változás és az ennek következtében kialakuló reflektancia függvény módosulás detektálása útján. Alig egy évvel később jelent meg az említett szenzort bemutató kutatócsoport következő publikációja, amelyben a gázfázis összetétel változásának detektálása mellett már szilárd/folyadék határfelületen végzett adszorpciós mérésekről is beszámolnak [28]. A bemutatott kísérletek során folyadék fázisban oldott monomer immunglobulin szilárd/folyadék határfelületen történő feldúsulását sikerült bizonyítani, lényegében előállítani az első funkcionalizált SPR chipet. Ezt követően sikerült regisztrálni az immunglobulinhoz kötődő antigén okozta eltolódást a reflektancia görbén, ezáltal igazolni, hogy a mérési módszer révén, kvázi kétdimenziós elrendezésben vizsgálható az antitest-antigén kapcsolódási reakció. Az 1983ban megjelent publikáció címében szereplő biológiai érzékelés („,biosensing”) kifejezés azóta is kulcsszava a tématerületen megjelenő írásos müveknek, posztereknek és előadásoknak. A méréstechnika viszonylagos egyszerüsége miatt ezt követően a módszert egyre szélesebb körben alkalmazták vékonyrétegek [29,30], biológiai modell rendszerek [31] és biokémiai folyamatok [24,25] vizsgálatára. Az 1980-as évek közepére egyre ismertebbé vált, hogy a technika lehetőséget biztosít a szenzorfelülethez kötött receptorok

\footnotetext{
${ }^{15}$ Halogénezett szén-hidrogén alapú általános érzéstelenítő (2-Bróm-2-klór-1,1,1-trifluoretán)
} 
és az oldatfázisú, nagy molekulatömegü ligandumok kölcsönhatásának valós idejü és jelölésmentes vizsgálatára. 1984-ben került megalapítására az úttörő jelentőségü Pharmacia Biosensor $A B^{16}$ nevü cég, amely a BIAcore ${ }^{T M}$ nevü SPR szenzor gyártását, forgalmazást és folyamatos fejlesztését tüzte ki célul. Az első berendezést az1990-es évben bocsátották kereskedelmi forgalomba [34], amelyet később publikációk sora igyekezett bemutatni és népszerüsíteni [35-37]. A fejlesztéseik eredményeként megjelent, a mai napig széles körben alkalmazott karboximetil-dextránnal borított szenzorfelületet részletesen bemutató publikáció [38], és eljárási szabadalmak kerültek benyújtásra, amelyek magában foglalták a szenzorfelület kialakítását és a receptor jellegü vegyület szilárd fázisra történő rögzítését [39,40]. Az analitikai célú felhasználás során a kérdéses molekula pár egyik tagja a szenzor felületén kerül rögzítésre, vagy az egyik molekulával kémiailag analóg (biomimetikus ${ }^{17}$ ) szenzorfelület kialakítására kerül sor [41]. Az immobilizálás megtörténhet kovalens kötéssel közvetlenül az arany bevonatú chip felületén, amennyiben a molekula tartalmaz megfelelö funkciós csoportot $[42,43]$. A szenzorfelület feletti evaneszcens tér dielektromos állandója a felület módosítása következtében megváltozik, ami módosítja a gerjesztési feltételt (2.14 egyenlet) és ezáltal a visszavert fény intenzitásának szög (vagy hullámhossz) függését. Az 5. ábra ezt a funkcionalizált állapotnak megfelelő feltételt (a) alaphelyzetként mutatja be, amely esetén az intenzitásgörbe minimum helye változatlan.
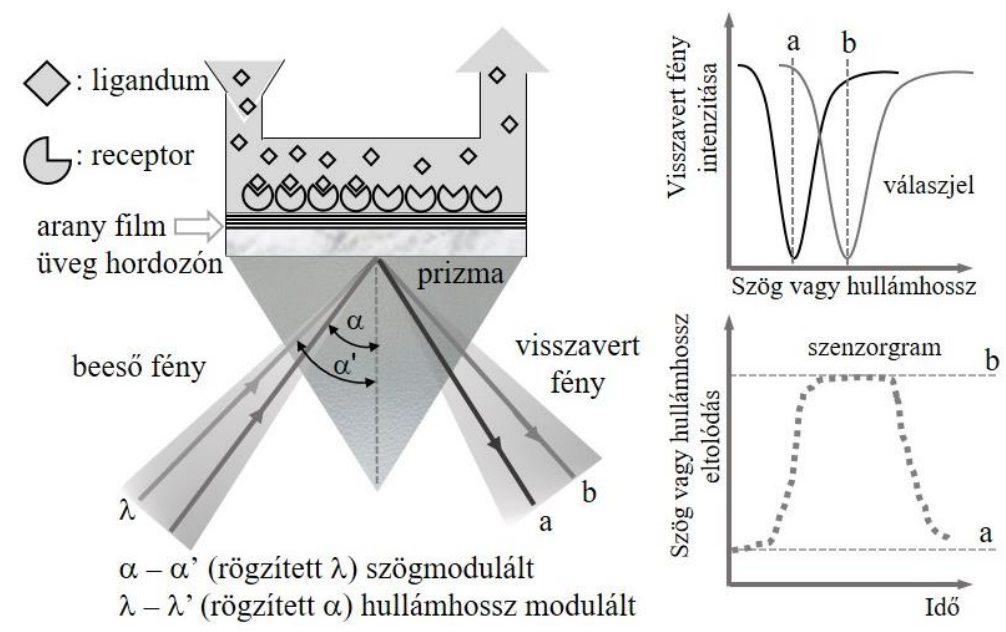

5. ábra: A szenzorfelületre integrált mintaterü SPR szenzor felépítésének és a szenzorjel keletkezésének sematikus ábrája

\footnotetext{
${ }^{16}$ A cég 1996-ban Biacore AB Corporation-ra változtatta a nevét, majd 2006 júniusában a GE Healthcare 390 millió dollárért megvásárolta a Biacore-t.

${ }^{17}$ Biológiai anyagok, mechanizmusok és folyamatok kialakulását, müködését vagy szerkezetét utánzó szintetikus rendszerek (Collins English Dictionary (ISBN: 978-0-00-828437-4) megfelelő bejegyzésének fordítása alapján).
} 
Mindezek eredményeként a minimumhely időfüggését leíró szenzorgramon az ordináta (szög vagy hullámhossz) állandó értéket vesz fel, ami alapvonalnak tekinthető. A másik kölcsönható molekula (analit/ligandum) jelenléte, amit adott koncentrációjú oldatának a szenzor felülete feletti áramoltatása biztosít, lehetőséget teremt a két fél közötti interakció kialakulására. Amennyiben a reverzibilis vagy irreverzibilis kötés alakul ki a receptor és a ligandum között, utóbbi határfelületi feldúsulása tovább módosítja a dielektromos állandó értékét és a szenzorjel eltolódását (b) eredményezi, ahogyan azt az $\mathbf{5}$. ábra igyekszik szemléltetni. A ligandummal telített szenzorfelülethez rendelhető jel eltolódásának mértéke arányos a szenzor egységnyi felületen megkötődő vegyület tömegével $\left(m_{s}\right)$, amelynek értéke felületi koncentrációvá $(\Gamma)$ konvertálható [44,45]. A kezdeti (a) és az állandósult állapot (b) között rögzített szenzorgram pedig a kötési folyamat kinetikájáról hordoz információt, hiszen az adott időpillanatban rögzített jeleltolódás mértéke egyben a szenzor felületen kialakuló kötési komplex koncentrációjával is arányos [46].

Az SPR spektroszkópia fejlödésével a makromolekulák közötti kölcsönhatások megismerését célzó kutatások száma rohamosan növekedett, így a növekvő igény hatására megjelentek a kísérlet tervezését és az adatelemzést segítő módszerek és az első kinetikai kiértékelést segítő szoftveres megoldás [47,48]. A kötési folyamatok sebességének és mennyiségi viszonyainak megfigyelése és rögzítése révén a kérdéses kémiai folyamat kinetikai és termodinamikai jellemzése valósítható meg, ami segítséget nyújthat a reakciók mechanizmusának molekuláris szintü megismerésére. A Myszka és Morton által fejlesztett CLAMP $^{\odot}$ [49] nevű kiértékelő program hosszú ideig elérhető ${ }^{18}$ volt, majd a többi hozzá hasonló szoftverrel (Scrubber, TraceDrawer, Genedata Screener®) azonos módon megszüntették a szabad felhasználás lehetőségét. Az adatgyüjtést, kísérlettervezést és kiértékelést segítő szoftverek az ezredfordulóra az olyan SPR berendezést gyártó cégek birtokába kerültek, mint például a GE Healthcare (Biacore sorozat) vagy a Reichert (Reichert 2SPR és Reichert 4SPR) és a szoftverek az adott gyártó által forgalmazott berendezéshez optimalizálva kerültek forgalomba. Az SPR szenzort gyártó cégek egyre nagyobb száma és az egymással versengő gyártók, illetve forgalmazók üzletpolitikája azt eredményezte, hogy megjelent az igény egy gyártótól független adatértékelési eljárás kidolgozására, amely lehetővé teszi a különféle berendezéseken végzett vizsgálatok összehasonlítását vagy akár együttes kiértékelést. Részleges megoldást jelenthet a

\footnotetext{
${ }^{18} \mathrm{http} / / /$ www.cores.utah.edu/interaction/software.html
} 
közelmúltban bemutatott koncepció, amely böngésző alapú szoftverplatformra támaszkodva segíti az SPR eredmények feldolgozását, elemzését és dokumentálását [50], azonban szabad felhasználású és univerzális kiértékelő szoftverről továbbra sem számol be a szakirodalom.

\subsection{A tanulmányozott kinurenin rendszer szerepe}

A triptofán aminosav oxidatív lebontásának a szerotonin képződése mellett a legjelentősebb útvonala az úgynevezett kinurenin útvonal (6. ábra). A metabolikus folyamat felelős a nikotinamid-adenin-dinukleotid és a nikotinamid-adenin-dinukleotid-foszfát koenzimek előállításáért [51]. A kinurenin rendszer több neuroaktív vegyületet foglal magába, amelyek részben neurotoxikus, részben neuroprotektív tulajdonságúak lehetnek. A metabolikus kaszkádban végtermékként keletkező kinurénsav (KYNA) és köztitermékként megjelenő kvinolénsav (QUIN) valamint a 3-hidroxi-kinurenin (3KYN) egyaránt neuroaktív vegyületek [52].

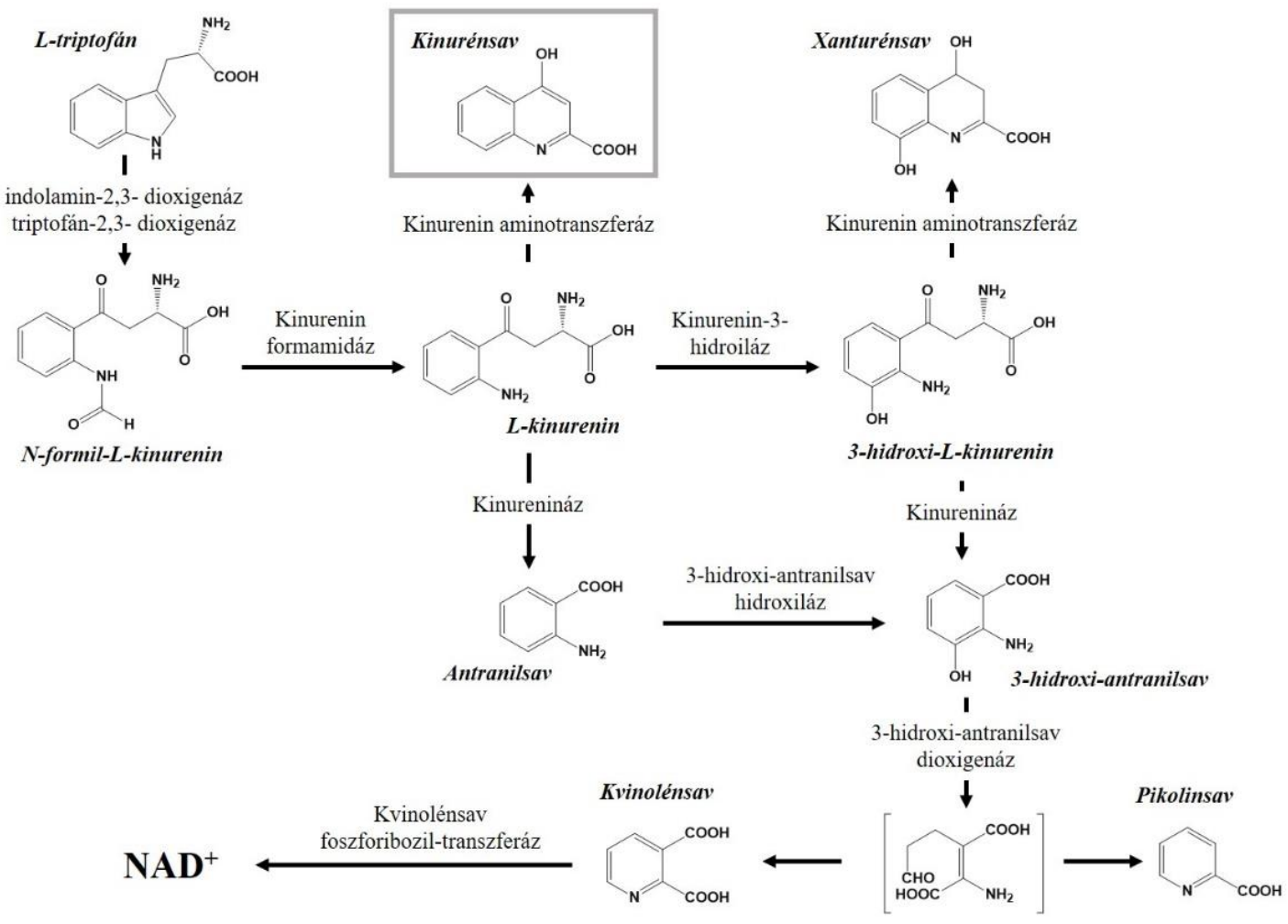

6. ábra: A kinurenin útvonalon keletkező, meghatározó szerepü metabolitok szerkezeti képletei

A 3KYN és a QUIN neurotoxikus hatású molekulák, amelyek szabad gyökök képződését segítik elö, a KYNA pedig az ionotróp glutamát-receptorok szervezeten belül keletkező 
(endogén) antagonistája, amely képes gátolni az $N$-metil- $D$-aszpartát (NMDA) és az AMPA típusú glutamát-receptorokat egyaránt [53,54]. A kinurenin rendszer szerepét a közönséges és az idegi fájdalom keletkezésében számos kísérleti adat igazolja, a molekuláris szintű hatásmechanizmus részletei azonban nem ismertek. Bizonyított azonban, hogy a KYNA az AMPA receptorokon dózisfüggő módon kettős hatást fejt ki, nevezetesen, kis dózisban (10 $\mu \mathrm{M})$ serkenti, majd lokális koncentrációjának növekedése esetén $(1000 \mu \mathrm{M})$ gátolja a receptor müködését [55].

A KYNA a glutamáterg szinapszisok közvetlen közelében felszabadulva hatékonyan befolyásolja ezek működését. Hirtelen fellépő oxigénhiányos állapot (hipoxia) vagy csökkent vérellátás (iszkémia) következtében a neuronokból és glia sejtekből nagy mennyiségű glutamát szabadul fel. A szinapszisokat elárasztó glutamát NMDA és AMPA receptorokat aktivál, melyek túlmüködése a sejten belüli kalcium szintet megemelve, reaktív oxigén gyökök felszabadulásához és sejthalálhoz vezethet. A kinurenin útvonalban kialakuló rendellenességek miatti neuronális zavarok kezelésére vagy az agyi hipoxia/iszkémia során létrejövő idegrendszeri károsodás (excitotoxicitás) kiküszöbölésére az endogén KYNA szint szabályozása nyújt lehetőséget. Számos tanulmány számol be a KYNA neuroprotektív hatásáról, segíthet többek között a traumás agykárosodás, a Parkinson-, Huntington-kór és a demencia megelőzésében. A központi idegrendszert érintő megbetegedésekben kimutatott csökkent vagy megnövekedett KYNA szint révén a vegyület vagy szerkezet és funkció analógjai, pontosabban ezek koncentrációjának szabályozása, új terápiás eljárások alapjául szolgálhat.

\subsection{Kutatócsoporti előzmények}

A MTA-SZTE Szupramolekuláris és Nanoszerkezetü Anyagok Kutatócsoportjában az SPR spektroszkópiai vizsgálatok 2012 óta egyre meghatározóbb szerepet kaptak. A 2017 évben elnyer újabb pályázatnak köszönhetően jelenleg a MTA-SZTE Biomimetikus Rendszerek Kutatócsoportjában folynak a kvázi kétdimenziós szenzortechnika által végzett vizsgálatok. A csoportban készült doktori értekezések sorában jelen dolgozat az első, amely makromolekulák és kismolekulás hatóanyagok közötti kölcsönhatások SPR méréstechnika általi modellezését mutatja be. A kísérleti munka elvégzéséhez a SZTE Fizikai Kémiai és Anyagtudományi Tanszékén müködő, egyedi tervezésü kétcsatornás hullámhossz modulált SPR platform (7. ábra) biztosította az elsődleges müszeres hátteret. A 7. ábra fotóin feltüntetett számok rendre az alábbi egységeket jelölik: 1. perisztaltikus pumpa, 2. 
polarizátor, 3. a prizmát, a szenzor chip-et és a mintakamrát befogó szerkezet, 4. spektrofotométer és száloptikája, 5. fényforrás, 6. szenzor chip, 7. a mintakamrákat és az áramlási csatornákat egybefoglaló fedél szétszerelt, valamint összeszerelt (8.) és rögzített (9.) állapotban.
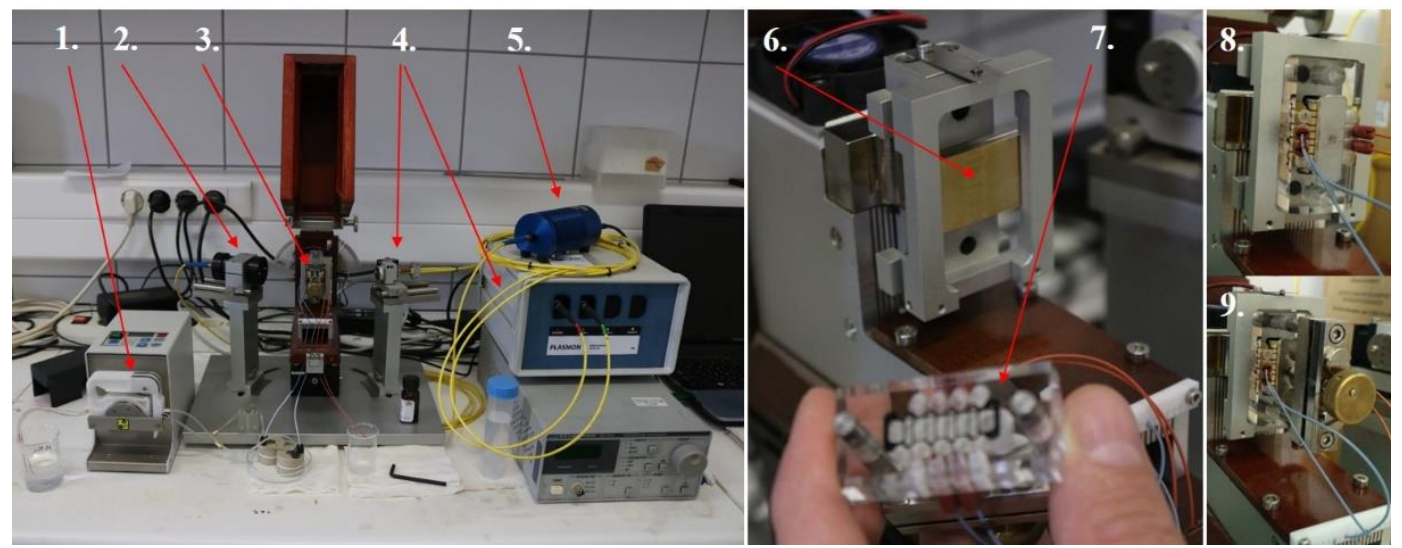

7. ábra: A SZTE TTIK Fizikai Kémiai és Anyagtudományi Tanszéken müködő kétcsatornás hullámhossz modulált SPR platform fotói

Az említett berendezés üzembe helyezése után az első publikált eredmény a dopamin és az IBU $L$-ciszteinnel funkcionalizált arany felületre történő szorpciójának vizsgálata volt. A közleményben a szenzorgramok állandósult állapothoz rendelhető telítési szakaszai alapján meghatározott adszorpciós izotermákról és a számított izoszter adszorpciós hőmennyiség alakulásáról számoltak be a kutatócsoport munkatársai [56]. A kiértékelési módszer alapját a szenzorgramok által meghatározott és felületegységre vonatkoztatott adszorbeált anyagmennyiségek $(\Gamma)$ egyensúlyi koncentrációtól való függése szolgáltatta. Ennek ismeretében a tetszőleges felületi borítottsághoz ${ }^{19}(\theta)$ rendelhető egyensúlyi koncentráció értékek hőmérsékletfüggése alapján számíthatóvá vált a gyógyszerhatóanyagok adszorpcióját kísérő izoszter entalpiaváltozás $\left(\Delta H^{0}{ }_{a d}\right)$ [57]. Az MTA-SZTE Idegtudományi Kutatócsoportja által indított, a KYNA szerepének és hatásmechanizmusának felderítésére irányuló projekthez kapcsolódva 2014-ben jelent meg az első olyan publikáció, amelyben AMPA receptort modellező polipeptidekkel (GluR1 201 230 és GluR1 $231-259$ jelölésü szakaszok) funkcionalizált szenzorral végzett vizsgálatok kerültek bemutatásra [58]. Ehhez a projekthez kapcsolódva kezdtem el 2015-ben azt a

\footnotetext{
${ }^{19}$ A felületi borítottság $(\theta)$ adszorbeálódó komponens adszorbeált többlete $\left(n^{s}\right)$ és a monomolekulás borítottsághoz tartozó adszorbeált anyagmennyiség $\left(n_{m}^{s}\right)$ hányadosa. Állandó hőmérsékleten a felületi borítottság és az adszorptívum oldatfázisbeli koncentrációja között a kísérleti izotermákra illeszthető $\theta=$ $c /(K+c)$ összefüggés állhat fenn.
} 
kutatási munkát, amely során egy új korábban elő nem állított AMPA receptort modellező polipeptid (GluR $1_{270-300)}$ és KYNA kölcsönhatásának SPR technika általi modellezése volt feladatom.

\subsubsection{Az AMPA receptort modellezö polipeptidek szintézise és karakterizálása}

A receptor modellként felhasznált polipeptidek kereskedelmi forgalomban nem szerezhetők be. Szintetikus úton történő előállítása során, a kiválasztott és Fmoc ${ }^{20}$-csoporttal védett aminosavak, szilárdfázisú peptidszintézis útján kerültek összekapcsolásra. A szilárdfázisú szintéziseket és a liofilizált termékek szemipreparatív fordított fázisú HPLC (Phenomenex Jupiter Proteo, C18, $10 \mu \mathrm{m}, 15$ x 250 mm) eljárással kivitelezett tisztítását Dr. Szolomájer János (SZTE ÁOK Orvosi Vegytani Intézet) végezte. A peptidek moláris tömegének meghatározását célzó, Finnigan TSQ-7000 típusú hármas-kvadrupól készülékkel kivitelezett tömegspektrometriás (MS) vizsgátokat Dr. Kele Zoltán (SZTE ÁOK Orvosi Vegytani Intézet) végezte.

Az ismert szerkezetü AMPA receptor négy alegysége [59,60] közül az 1-es alegység modelljeként két aminosav lánc került előállításra. A 201-es valintól a 230-as leucinig terjedő, VVDCESERLNAILGQIIKLEKNGIGYHYIL aminosav sorrendü és GluR1201-230 jelölésű polipeptid, amelynek számított moláris tömege $\mathrm{M}=3210,61 \mathrm{~g} \mathrm{~mol}^{-1}$, míg az MS technikával meghatározott érték $\mathrm{M}=3209,98 \mathrm{~g} \mathrm{~mol}^{-1}$. Emellett pedig a 231-es alanintól a 259-es treoninig terjedő, ANLGFMDIDLNKFKESGANVTGFQLCNYT aminosav sorrendű és GluR1231-259 jelölésű szakasz. Utóbbi számított moláris tömege $\mathrm{M}=3400,97 \mathrm{~g}$ $\mathrm{mol}^{-1}$, míg az MS technikával meghatározott érték $\mathrm{M}=3400,56 \mathrm{~g} \mathrm{~mol}^{-1}$. A fragmensek szintézise és karakterizálása mellett az arany felületre kötött szekvenciák és a KYNA között kialakuló kötés analízisét molekuladinamikai (MD) szimulációk révén Dr. Bogár Ferenc (SZTE ÁOK Orvosi Vegytani Intézet) végezte.

Az NMDA és az AMPA típusú glutamátreceptorok és KYNA valamit KYNA analógok kölcsönhatását modellező, kvantumkémiai szerkezet és affinitás szimulációk csupán az NMDA receptor esetén álltak rendelkezésre [61]. Ezáltal az elméleti kémiai számítások mindenképp szükségesek voltak és ezek eredményei kiindulási alapul szolgáltak a szenzorikai vizsgálatok tervezése és kiértékelése során. A GluR1 201-230 és GluR1231-259 polipeptidek szerkezete a LOMETS ${ }^{21}$ (Local Meta-Threading-Server) nevü on-line

\footnotetext{
20 9-Fluorenil-metiloxi-karbonil-klorid

${ }^{21}$ https://zhanglab.ccmb.med.umich.edu/LOMETS/
} 
szolgáltatás révén generálódott, amely negyedleges szerkezet szintü becslést tesz lehetővé [62].

\subsubsection{Az SPR szenzor felületének funkcionalizálása AMPA receptort modellezö} polipeptidekkel

A kutatócsoport munkatársai két eltérő szekvenciájú polipeptiddel funkcionalizált SPR szenzor kialakítása során a fiziológiás körülményeket közelítő, neutrális $(\mathrm{pH}=7,4)$ kémhatású foszfát pufferben (PBS) oldott, $\mathrm{c}=30 \mu \mathrm{M}$ koncentrációjú polipeptid-oldatot áramoltattak $\left(\mathrm{q}_{\mathrm{v}}=50 \mu \mathrm{L}\right.$ perc $\left.^{-1}\right)$ a szenzor arany felülete felett, majd állandósult állapotnak megfelelő szenzorjel elérését követően a puffer ismételt átáramoltatása révén távolították el a felesleges polipeptidet. A szenzorjel pufferes lemosását követő és a polipeptid injektálását megelőző értéke közötti eltérés alapján valószínűsíthető volt, hogy a fragmensek irreverzibilis módon kötődnek a szenzor felületéhez. Az irreverzibilisen kötött polipeptid réteg kialakulása a szenzor arany felülete és a peptidek 204-es illetve a 256-os helyzetü ciszteinjének kéntartalmú funkciós csoportja között kialakuló kovalensen kötésnek köszönhető [56]. A receptor modellel módosított szenzorfelület kialakítását követően a korábban alkalmazottal azonos összetételü pufferes közegü KYNA oldatokat vezettek a szenzorfelületre. Az oldatsorozat egyes tagjaiban a KYNA koncentrációja 0,1 és 5,0 mM között változott a méréseket pedig 10 és $40 \mathrm{C}^{\circ}$ közötti hőmérséklet tartományban, négy különböző hőmérsékleten végezték el. A koncentráció és hőmérsékletfüggő szenzorgramok asszociációs telítési szakaszához rendelhető hullámhossz eltolódás értékek alapján, meghatározásra kerültek a KYNA szorpciós izotermái. A kísérleti úton meghatározott adatpárok izoterma egyenlettel történő illesztését követően tetszőlegesen választott $\theta$ érték mellett vált számíthatóvá az adott borítottsághoz rendelhető entalpiaváltozás $\left(\Delta H_{a d}^{0}\right)$. Mindezek ismeretében a kölcsönható partnerek sztöchiometriai arányának függvényében is vizsgálhatóvá vált a szorpciós folyamatot kísérő hőeffektus, amelynek extrémuma $\left(\Delta H^{0}{ }_{a d} \approx\right.$ $-40 \mathrm{~kJ} \mathrm{~mol}^{-1}$ ) $\theta \approx 1$ borítottság, valamint 1,0:1,3 receptor:ligandum mólarány esetén jelent meg. A szenzorgramok kinetikai modell általi kiértékelése, a megfelelő szoftveres kiértékelési eljárás hiányában egyik polipeptid fragmens esetében sem került kivitelezésre. 


\section{Célkitüzések}

A 2007 és 2017 között MTA-SZTE Szupramolekuláris és Nanoszerkezetű Anyagok, majd 2017-től MTA-SZTE Biomimetikus Rendszerek Kutatócsoport első megalakulása óta egyik fö kutatási területeként tartja számon az önszerveződő biológiai rendszerek, szilárd/folyadék határfelületi modellezését és vizsgálatát lehetővé tévő szenzortechnikák fejlesztést és alkalmazását. A csoportban folyó kutatásokhoz 2015 őszén csatlakoztam és ekkor fogalmazódott meg a jelen dolgozat anyagát képző kutatási munka terve.

Kutatómunkám során elsődleges célom volt egyrészt az SPR szenzor arany felületén, fehérjék, di- és tri-peptidek valamit a Cys kötődése révén kialakított adszorpciós réteg analízise révén a molekuláris felületigény meghatározása és a molekulák orientációjának becslése. Egyes vegyületek esetében lehetőség adódott arra is, hogy a módszer alkalmazhatóságának igazolásához a számított felületigényeket QCM technika által szolgáltatott értékekkel, kisszögü röntgenszórás (SAXS) vizsgálatból származó szerkezeti információkkal valamit irodalmi adatokkal vethessem össze. A monomolekulás adszorpciós réteget feltételező számítások eredményei nagymértékben hozzájárultak a tiolcsoportot tartalmazó molekulák és $\mathrm{AuCl}_{4}{ }^{-}$-ionok jelenlétében, vizes közegben képződő, koordinációs polimer struktúra és fluoreszcens nanoklaszterek kialakulásának magyarázatához.

Ezen túlmenően kutatómunkám további kitüntetett célja volt a szenzorfelülethez rögzített makromolekulák és a hozzájuk kötődő kismolekulás ${ }^{22}$ hatóanyagok mennyiségi viszonyainak vizsgálata során a megfelelő adatfeldolgozási és kiértékelési eljárás kidolgozása, mely révén az egyes tanulmányozott rendszerek esetén a kötési folyamatok sebességi $\left(k_{i}\right)$ és egyensúlyi $\left(K_{A}\right)$ állandóinak meghatározása válik lehetővé.

Az értekezés elkészítése során kidolgozott kiértékelési eljárással többek között IBU és BSA közötti, kötés jellegü kölcsönhatás kémhatás függő vizsgálatát végeztem el a fehérjével-funkcionalizált SPR szenzorfelület kialakítása révén. A rögzített szenzorgramok kinetikai modellel történő illesztése révén lehetőség nyílt a hatóanyag megkötődéséhez és disszociációjához rendelhető sebességi állandók meghatározására. A kötési paraméterek független méréssel történő megerösítése érdekében ITC vizsgálatok is történtek. Az eredmények megerősítették a BSA-alapú kolloidális gyógyszerhordozó rendszer kioldódási vizsgálatai során az IBU felszabadulásának sebességéről szerzett információkat.

\footnotetext{
${ }^{22}$ Az SPR technika tipikusan makromolekulák közötti kölcsönhatások vizsgálatának az eszköze, ezzel

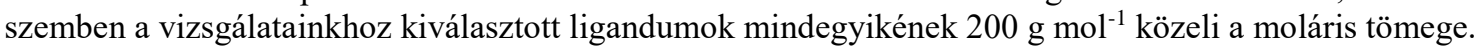


Kutatási munkám gerincét az AMPA receptor modell fragmensek és KYNA kölcsönhatásának hőmérsékletfüggő SPR vizsgálata képezte. Ezek célja az említett kölcsönhatás termodinamikai paramétereinek meghatározása volt, amelyek megerösítették a korábban feltételezett kötési mechanizmus helyességét. Ezen felül a receptor modellek alkalmazhatóságát bizonyítandó, összehasonlító jellegü vizsgálatokat is terveztem és kiviteleztem, melyek során a tanulmányozott (GluR1231-259 és GluR1270-300) polipeptid fragmenseket szérum fehérjékkel helyettesítettem. Utóbbiak esetében a meghatározásra kerülő állapotfüggvények várhatóan nem a modell polipeptidekre jellemző specifikus kölcsönhatás jelenlétét igazolják.

\section{Felhasznált anyagok és vizsgálati módszerek}

\subsection{Felhasznált vegyszerek}

A mérések kivitelezése során felhasznált finomvegyszerek analitikai tisztaságúak voltak, így további tisztítás nélkül alkalmaztam azokat. Az oldószerként alkalmazott, $\mathrm{NaCl}$ $(0,15 \mathrm{M})$ tartalmú foszfát-puffert $(\mathrm{pH}=7,4)$ heti rendszerességgel készítettem $0,5 \mathrm{dm}^{3}$ térfogatú részletekben. A pufferoldat (továbbiakban PBS) készítése során 4,383 g NaCl-ot, 0,4902 $\mathrm{g} \mathrm{NaH}_{2} \mathrm{PO}_{4} \times \mathrm{H}_{2} \mathrm{O}$-ot és $0,7098 \mathrm{~g} \mathrm{Na}_{2} \mathrm{HPO}_{4}$-ot oldottam, 0,5 dm $\mathrm{dé}^{3}$ tegatú, nagy tisztaságú, Milli-Q vízben (Millipore, Milli-Q Integral3, vezetőképesség: $18,2 \mathrm{M} \Omega \mathrm{cm} 25^{\circ} \mathrm{C}$ on). A pufferoldatok pH értékét az elkészítésüket követően ellenőriztem, hidrogénionszelektív üvegelektródot (Mettler-Toledo FiveEasy ${ }^{\mathrm{TM}}$ ) alkalmazva. A receptor modellek és fehérjék valamit a potenciális hatóanyagok oldatait minden esetben közvetlenül a felhasználás előtt készítettem el. Az AMPA receptor GluR1-es alegységét modellező GluR1 $1_{231-259}$ és GluR1270-300 polipeptideket Prof. Dr. Tóth Gábor (SZTE ÁOK Orvosi Vegytani Intézet) csoportja állította elő szilárdfázisú peptidszintézis útján, amelyeket tisztításuk és moláris tömeg meghatározását követően liofilizált formában bocsátották rendelkezésünkre. A vizsgálatokhoz felhasznált vegyületek nevét, képletét (és/vagy ezt helyettesítve az azonosításukra használt rövidítéseket és a polipeptidek esetén aminosav sorrendjüket), moláris tömegét és gyártóját (vagy előállítóját) az alábbi felsorolás foglalja össze.

- Citromsav-1-hidrát $\left(\mathrm{C}_{6} \mathrm{H}_{8} \mathrm{O}_{7} \times \mathrm{H}_{2} \mathrm{O}, \mathrm{M}_{\mathrm{r}}=210,14 \mathrm{~g} \mathrm{~mol}^{-1}\right)$ Molar Chemicals

- Dinátrium-hidrogénfoszfát $\left(\mathrm{Na}_{2} \mathrm{HPO}_{4}, \geq 98,5 \%, \mathrm{M}_{\mathrm{r}}=141,96 \mathrm{~g} \mathrm{~mol}^{-1}\right)$ Sigma-Aldrich

- GluR1 231-259 (ANLGFMDIDLNKFKESGANVTGFQLCNYT, $\mathrm{M}_{\mathrm{w}}=3400,56$ $\mathrm{g} \mathrm{mol}^{-1}$ ) SZTE ÁOK Orvosi Vegytani Intézet 
- GluR1 $1_{270-300}$ (CKNSDARDHTR VDWKRPKYTSALTYDGVKVM, $\mathbf{M}_{\mathrm{w}}=$ $3639,8 \mathrm{~g} \mathrm{~mol}^{-1}$ ) SZTE ÁOK Orvosi Vegytani Intézet

- Humán szérum albumin (HSA, $\geq 98,0 \%, \mathrm{M}_{\mathrm{w}}=66,4 \mathrm{kDa}$ ) Sigma-Aldrich

- Ibuprofén (IBU, $\mathrm{C}_{13} \mathrm{H}_{17} \mathrm{O}_{2} \mathrm{Na}, \geq 98 \%, \mathrm{M}_{\mathrm{r}}=228,26$ ) Sigma-Aldrich

- Kinurénsav (KYNA, $\left.\geq 98 \%, \mathrm{C}_{10} \mathrm{H}_{7} \mathrm{NO}_{3}, \mathrm{M}_{\mathrm{r}}=189,17\right)$ Sigma-Aldrich

- $\quad L$-cisztein (Cys, $\left.\geq 99,5 \%, \mathrm{C}_{3} \mathrm{H}_{7} \mathrm{NO}_{2} \mathrm{~S}, \mathrm{M}_{\mathrm{r}}=121,16 \mathrm{~g} \mathrm{~mol}^{-1}\right)$ Fluka

- L-ciszteinil-triptofán (Cys-Trp, $\mathrm{M}_{\mathrm{r}}=308,10 \mathrm{~g} \mathrm{~mol}^{-1}$ ) SZTE AOK Orvosi Vegytani Intézet

- L-glutation ( $\mathrm{GSH}, \mathrm{C}_{10} \mathrm{H}_{17} \mathrm{~N}_{3} \mathrm{O}_{6} \mathrm{~S}, \geq 98,0 \%, \mathrm{M}_{\mathrm{r}}=307,32 \mathrm{~g} \mathrm{~mol}^{-1}$ ) Sigma-Aldrich

- $\operatorname{Lizozim}\left(\mathrm{LYZ}, \geq 90,0 \%, \mathrm{M}_{\mathrm{w}}=14,3 \mathrm{kDa}\right)$ Sigma-Aldrich

- $\quad$ Nátrium-klorid $\left(\mathrm{NaCl}, \geq 98 \%, \mathrm{M}_{\mathrm{r}}=58,44\right)$ Molar

- Nátrium-dihidrogénfoszfát $\left(\mathrm{NaH}_{2} \mathrm{PO}_{4} \times \mathrm{H}_{2} \mathrm{O}, \geq 99 \%, \mathrm{M}_{\mathrm{r}}=156,10\right)$ Sigma-Aldrich

- Marha szérum albumin (BSA, $\geq 98,0 \%, \mathrm{M}_{\mathrm{w}} \sim 66,5 \mathrm{kDa}$ ) Sigma-Aldrich

A fehérje alapú kolloidális gyógyszerhordozó fejlesztéséhez kapcsolódó vizsgálatokban, amelyek során a BSA és IBU közötti kötés jellegű kölcsönhatás modellezésére került sor a PBS mellett, a savas kémhatás $(\mathrm{pH}=3,0)$ biztosítása végett a megfelelő összetételü citrát/foszfát puffert (továbbiakban CPS) alkalmaztam. A savas kémhatású pufferoldat készítéshez 4,383 g NaCl-ot, 1,4248 g $\mathrm{g}_{6} \mathrm{H}_{8} \mathrm{O}_{7} \times \mathrm{H}_{2} \mathrm{O}$-ot és 0,7098 g Na $2 \mathrm{HPO}_{4}$-ot oldottam, $0,5 \mathrm{dm}^{3}$ térfogatú, nagy tisztaságú, Milli-Q vízben, majd a puffer $\mathrm{pH}$ értékét a foszfát pufferével azonos módon ellenőriztem.

\subsection{A kísérletek során alkalmazott vizsgálati módszerek}

\subsubsection{Felületi plazmon rezonancia (SPR) spektroszkópia}

A SPR méréseket egy szabályozható hőmérsékletü, kétcsatornás, hullámhossz modulált berendezésen végeztem el, amelynek fejlesztését a Cseh Tudományos Akadémia prágai Fotonikai és Elektronikai Intézetében (Institute of Photonics and Electronics) müködő és Jiří Homola ${ }^{23}$ professzor által vezette csoport végezte [63]. A hullámhossz modulált berendezés két érzékelő csatornájához két különálló áramlási kamra áll rendelkezésre, amelyek térfogata egyenként $0,5 \mu \mathrm{L}$. Az érzékelö chip befogó szerkezete egy $20 \times 26 \mathrm{~mm}^{2}$-es mikroszkóp tárgylemez befogadására alkalmas keret. Ebbe kerül elhelyezésre a szenzor chip, amely egy üveg hordozó felületén kialakított $1,2 \mu \mathrm{m}$ vastagságú

\footnotetext{
${ }^{23}$ https://www.ufe.cz/en/jiri-homola
} 
teflon filmen kialakított $25 \mathrm{~nm}$ vastagságú aranyréteg (fotója a 7. ábra bal oldalán látható a befogó keretbe foglalt állapotban). A mérés közben ez az arany felület alkotja az áramlási kamrák egyik oldalát, ezáltal biztosítva a vizsgálandó vegyület oldatának és a szenzor felületének kontaktusát. Az üveg hordozó ellentétes oldala bevonatmentes, ez a felület csatlakozik immerziós olaj rétegen keresztül az áramlási kamrák mögött található prizmához, kialakítva a szenzor müködéséhez szükséges elrendezést. A chip felületét mikrofluidikai áramlási rendszer (fotója szintén a 7. ábra bal oldalán látható) köti össze a mintatartó edényekkel és egy perisztaltikus pumpa biztosítja az oldatok szállítását az áramlási csatornákban. A prizma (a), a szenzor chip (b), a mintakamrák oldalát alkotó matrica (c), a kamrákat áramló rendszerbe integráló fedél (d) és az áramlási csatornák (d) robbantott szerelési terve a $\mathbf{8}$. ábra $\mathrm{A}$ részén látható. Az összeszerelt állapotot a $\mathbf{8}$. ábra $\mathbf{B}$ része szemlélteti, míg a $\mathbf{C}$ részén vázolt metszeti kép igyekszik bemutatni az folyadékáram (szaggatott vonal) és fény (nyilak) útját a szenzorfelület ellentétes oldalain.


8. ábra: A vizsgálatok során alkalmazott kétcsatornás hullámhossz modulált SPR platform központi egységének vázlata (A: robbantott szerelési terv, B: összeszerelt állapot, C: metszeti kép)

A berendezés fényforrása egy Ocean Optics HL-2000 márkajelzésű wolframhalogénizzó, amely 260 és $2400 \mathrm{~nm}$ közötti hullámhossz tartományban 6,8 $\mathrm{mW}$ teljesítményt képes biztosítani. A visszavert fény intenzitásának változását 574-1000 nm-es hullámhossz tartományon egy IPE AS CR S2010 típusú spektrofotométer méri és rögzíti. A fotométer USB csatlakozáson keresztül egy személyi számítógéphez kapcsolódik, amelyen a szenzorgrammok regisztrálását és megjelenítését az SPR UP 1.1.11.3 (2014 IPE AS CR) szoftverrel végzi. A rögzített szenzorgramok vagyis az idő függvényében regisztrált hullámhossz eltolódás értékek ASCI formátumú szövegfájl formájában menthetők el. Ezen adatok feldolgozásának és kiértékelésének módja az „Eredmények és értékelésük” fejezet vonatkozó alfejezeteiben kerül bemutatásra a részletes kísérleti körülmények ismertetése 
mellett. A mérések során alkalmazott áramlási sebesség 25 és $50 \mu \mathrm{L} \mathrm{perc}^{-1}$ között változott, a mérések állandó hőmérsékletét pedig a Newport Corporation által forgalmazott LDT5525B típusú termosztát és vezérlő egysége biztosította, a szenzorfelület környezetében \pm $0,2{ }^{\circ} \mathrm{C}$ pontossággal.

\subsubsection{Kvarckristály mikromérleg (QCM) technika}

A molekuláris biofilmek és szervetlen vékonyrétegek oldatfázisból történő szilárd/folyadék határfelületi feldúsulásuk általi kiépülésének kinetikája és azok adszorpciós sajátsága egyaránt nagy pontossággal követhető és mérhető QCM segítségével. A mérési eljárás alapja egy piezoelektromos effektus ${ }^{24}$ alapján müködő szenzor, amely az arannyal bevont és váltóárammal magas frekvenciájú rezgésbe hozott kvarckristály oszcillációnak tömegfüggése révén képes detektálni az arany felületre adszorbeálódott anyag mennyiségi változását. A QCM méréseimet egy Stanford Research System 200 típusú mikromérlegen végeztem. A szabványosított méretü kvarckristály és felületén kialakított króm/arany vékonyréteg alkotta szenzor chip egy megfelelően kialakított méröfejben nyugszik, amely egyrészt az oszcillátoron keresztül csatlakozik a detektorhoz, másrészt tetszőleges mintaadagoló berendezéshez kapcsolható. A müszer számítógépes vezérlése és az adatok rögzítése az SrsQcm200 típusú szoftverrel történt. A mért frekvencia értékek és a kristályra adszorbeált tömeg közötti összefüggés a Sauerbrey-egyenlet (4.1.) adja meg,

$$
\Delta f=-\frac{2 f_{0}^{2}}{A \sqrt{\rho_{q} \mu_{g}}} \Delta m
$$

ahol $f_{0}(\mathrm{~Hz})$ a kristály rezonancia frekvenciája, $\Delta f$ a tiszta szenzorfelület és a mérendő anyagra jellemző frekvenciaértékek különbsége, $A$ kristály aktív felülete, $\rho_{q}$ a kristály sürüsége $\left(\rho_{q}=2,648 \mathrm{~g} \mathrm{~cm}^{-3}\right), \mu_{g}$ a kristály nyírási modulusa $\left(\mu_{g}=2,947 \times 10^{11} \mathrm{~g} \mathrm{~cm}^{-1} \mathrm{~s}^{-2}\right)$ és $\Delta m$ a tömegváltozás $(\mathrm{g})$. Az általam hasznát kvarckristály mérleg esetében a 4.1. egyenlet paraméterei rögzített értékek, amelyek egyetlen konstansba $\left(k_{q}=17,668 \mathrm{ng} \mathrm{cm}^{-2} \mathrm{~Hz}^{-1}\right)$ foglalhatók, így a szenzor felületén bekövetkező adszorpció miatti frekvencia-csökkenéssel arányos tömegnövekedés a 4.2. egyenlet szerint egyszerü formula alapján számítható.

$$
\Delta m=-\Delta f \cdot k_{q}
$$

A mérések kivitelezése $\mathrm{T}=25^{\circ} \mathrm{C}$-on történt statikus körülmények között, amelyek során a mérőfej a vizsgált molekula vizes oldatába merült. A felületigények meghatározásához az

\footnotetext{
${ }^{24}$ A piezoelektromos kvarc az elektromos tér hatására megváltoztatja a méretét vagy inverz megközelítésben a nyomás hatására felületein elektromos potenciálkülönbség jelentkezik.
} 
alábbi frissen készített vizes oldatokat használtam fel: Cys: 0,1; 1,0;3,0; 5,0; 10,0 mM, GSH: 0,$1 ; 1,0 ; 3,0 ; 10,0 ; 20,0 \mathrm{mM}$. A Cys-Trp esetén a rendelkezésre álló kis anyagmennyiség és a kísérletek prioritási sorrendje ${ }^{25}$ következtében QCM mérések nem készültek.

\subsubsection{Izoterm titrációs mikrokalorimetria (ITC)}

A kalorimetriás méréseket egy VP-ITC (Microcal, USA) titrációs berendezéssel végeztem, amelynek két különálló és nagy érzékenységű fütő/hütő-rendszerét visszacsatolási elven alapuló mikroelektronika vezérel. Az elsődleges fütő/hütő rendszer egy referenciacella hőmérsékletét tartja állandó értéken, az általában $1{ }^{\circ} \mathrm{C}-\mathrm{kal}$ alacsonyabb hőmérsékletü adiabatikus külső köpennyel szemben. A másik fütőrendszer pedig a mérőcella és a referenciacella közötti hőmérséklet különbséget egyenlíti ki, amely elöbbiben a mintaadagolás révén létrejövő hőjelenség miatt alakul ki. A mérés során a berendezés a 9. ábra bal oldalán vázolt minta kamrát mellette elhelyezkedő referencia cellával igyekszik azonos hőmérsékleten tartani és az ehhez szükséges fütőteljesítményt méri.
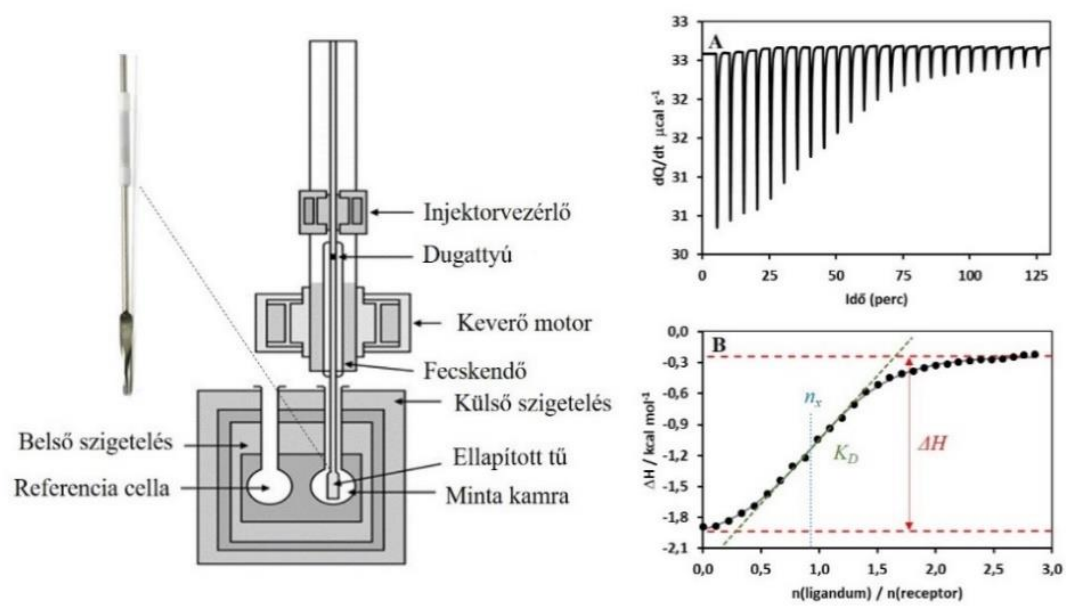

9. ábra: A vizsgálatok során alkalmazott VP-ITC típusú kaloriméter vázlata, valamint a mérési módszert jellemző reprezentatív kalorimetriás görbe (A) és entalpogram (B)

Amennyiben endoterm reakció játszódik le a mintacellában, akkor ez a folyamat hőt von el, így a cellát jobban kell füteni, mint a referencia cellát. Ha a reakció exoterm, akkor a hőfelszabadulás miatt a mintacellát kevésbé kell füteni az azonos hőmérsékleten tartáshoz. A fütő, illetve hűtő teljesítmény időbeni változása szolgáltatja azt a hőmennyiség változást $(d Q / d t)$, amelyet a vezérlő szoftver a mérés közben eltelt idő függvényében rögzít. A berendezés sematikus vázlata mellet a 9. ábra jobb oldalán látható reprezentatív grafikonok

\footnotetext{
${ }^{25}$ A dipeptid elsődlegesen az Au tartalmú nanohibrid rendszerek [68] vizsgálatát célzó kutatások érdekében
} került előállításra. 
a módszer által szolgáltatott tipikus jelsorozatot (9. ábra A) illetve ennek feldolgozott adatsorát (9. ábra B) szemléltetik.

A mintaadagolás során az automatizált injektor elöre meghatározott időközönként kevertetés közben a cellában lévő oldathoz (a receptor jellegü molekula oldata) adagolja a titráló ligandum oldatának egy kis mennyiségét, ami a mérőcellában egy termikus esemény bekövetkezését eredményezi. A számítógéppel vezérelhető injektorból a titráló oldat adagolása akár $1 \mu \mathrm{L}$ léptékben is történhet, fecskendőjének a mintakamrába benyúló forgó tüje pedig keverőlapát kialakítású, így a mintatérbe történő adagolás és homogenizálás együttesen megoldott. A mérőcella térfogata a gyártó cég által kalibrált állandó érték $(1,4163$ $\mathrm{cm}^{3}$ ), így ennek megfelelő térfogatú és megválasztott koncentrációjú receptor jellegü makromolekula (peptid vagy fehérje) pufferes oldatával töltöttem fel Hamilton fecskendő segítségével. Az injektor fecskendőjének hasznos térfogata $280 \mu \mathrm{L}$, ebbe került felszívásra a különbözö potenciális hatóanyagok pufferes oldata. Minden vizsgálat esetében 290 fordulat perc $^{-1}$ keverési sebességet alkalmaztam, két injektálási lépés között a várakozás ideje 5 perc, a titráló oldat beadagolásának ideje pedig egy adagolási lépésben 30 másodperc $(s)$ volt.

\subsubsection{Kisszögü röntgenszórásos (SAXS) szerkezetvizsgálat}

A LYZ, BSA és HSA fehérjék továbbá a BSA-alapú, IBU-tartalmú gyógyszerhordozó vizes közegű makromolekulás kolloidjainak méret meghatározását és szerkezetvizsgálatát SAXS méréstechnikával végeztük. Az eljárás kiválóan alkalmazható az 1-100 nm mérettartományú inhomogenitásokkal leírható rendszerek morfológiájának jellemzésére. A SAXS mérések egyaránt információt szolgáltatnak a részecskék méretérool, alakjáról, aggregációs állapotáról, a diszperz rendszer fajlagos felületéről és porozitásáról.

A pordiffrakciós technikától eltérően a mérés során a kis szögek tartományában $\left(0,05 \geq 2 \Theta^{\circ} \leq 10\right)$ fellépő röntgenszórás intenzitásának változása kerül detektálásra a szóródás szögének függvényében. A szóródási szög függvényében detektált intenzitás a szórásgörbe, amely reprezentálása és feldolgozása során a szórási szög helyett a szórásvektort használják független változóként. A röntgensugarak a mintát alkotó elektronokkal kölcsönhatásba lépve az eltérő elektronsürüségü fázisok határfelületein szóródnak. Detektálható kisszögü szórás ezáltal csak akkor jöhet létre, ha a szóró centrumok (kolloid méretü részecskék) és az őket körülvevő közeg az elektronsürüsége elegendő mértékben tér el. 
A SAXS vizsgálatok kivitelezésében Dr. Sebők Dániel (SZTE TTIK Fizikai Kémiai és Anyagtudományi Tanszék) volt segítségemre. A szórásgörbék egy Philips PW 1820 típusú röntgencsővel (CuKa sugár, $\lambda=0,154 \mathrm{~nm}, 40 \mathrm{kV}, 30 \mathrm{~mA})$ szerelt $\mathrm{KCEC} / 3$ típusú kompakt Kratky-kamerával kerültek rögzítésre $2 \mathrm{~mm}$ átméröjü kapilláris mintatartókban. A szórt sugárzás intenzitása egy PDS 50M (M. Braun AG, München) típusú helyérzékeny detektorral lett mérve a $2 \Theta=0,05-8^{\circ}$ szögtartományban. A szórásfüggvények ismeretében a háttér (puffer oldat) szórásának kivonása után történt a fehérjékre és fehérje alapú kolloidokra vonatkozó szerkezeti paraméterek meghatározása. A szórásfüggvények klasszikus (Guinier- és Kratky analízis) reprezentációit felhasználó kiértékelési eljárásokon túl a szórásgörbék modellillesztéshez és a párkorrelációs függvények számításához a SANSView nevü szoftver nyújtott segítséget. 


\section{Eredmények és értékelésük}

\subsection{Cisztein-tartalmú di- és tripeptidek valamint fehérjék adszorpciója arany felületen}

\subsubsection{Arany felülethez irreverzibilisen kötödö molekulák immobilizálása SPR szenzor felületén}

Az SPR szenzor arany felületéhez várhatóan kovalensen kapcsolódó molekulákkal/fehérjékkel-funkcionalizált SPR szenzorfelület kialakítása során első lépésben a vizes közegű PBS-oldat szenzorfelület feletti áramoltatására, majd az alapvonal rögzítése után a molekulákat/fehérjéket tartalmazó PBS oldat bejuttatására került sor. A kétcsatornás berendezés egymással ekvivalens áramlási csatornái közül referencia ágnak tekintjük azt a csatornát, amelyben folyamatosan a vizsgált rendszer oldószere áramlik és minta ágnak azt, amelyre a molekula/fehérje oldatát és oldószerét (puffer) felváltva vezetjük. A mérés kivitelezését a HSA esetén mutatom be részletesen, a többi rendszer mérésének kivitelezése hasonló módon történt. A 10. ábra A része szemlélteti a detektált reflektancia görbék helyzetét abban az esetben, amikor a minta és referencia csatornán keresztül egyaránt PBS áramlik a szenzorfelület felett.
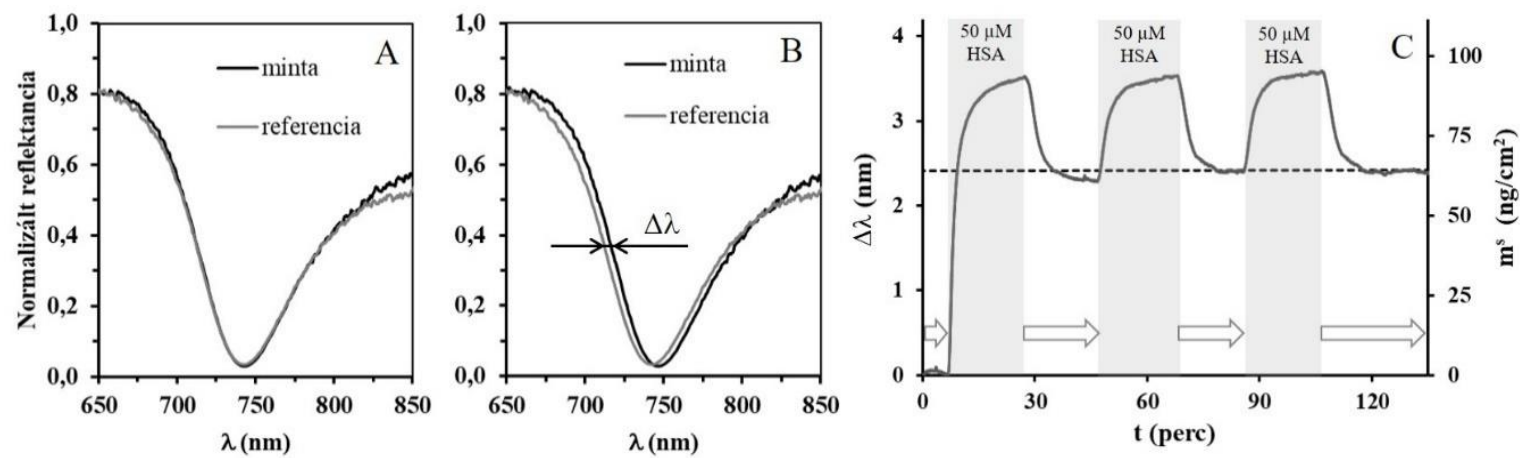

10. ábra: A HSA arany szenzor felületre történő immobilizálása során rögzített jellemző reflektancia görbék (A: mindkét csatornán PBS áramlik, B: a minta csatornában HSA, míg a referencia csatornában PBS áramlik) és szenzorgram $\left(\mathrm{C}: \mathrm{T}=25^{\circ} \mathrm{C}, q_{v}=50 \mu \mathrm{L}\right.$ perc ${ }^{-1}$,

$$
\left.\mathrm{c}_{\mathrm{HSA}}=50 \mu \mathrm{M}\right)
$$

Ekkor az említett csatornák esetében a reflektancia görbék minimuma egyaránt $742 \mathrm{~nm}$ hullámhossz értéknél jelenik meg, ahogyan a 10. ábra A részén látható. Ezáltal az idő függvényében rögzített szenzorjel ( $\Delta \lambda=\Delta \lambda_{\text {minta }}-\Delta \lambda_{\text {referencia }}$ ) kezdeti szakaszán ( 0 és 7 perc között) ennek megfelelő közel zérus érték képezi az alapvonalat, ahogyan az a 10. ábra C részén látható. A HSA esetén, a frissen készített $\mathrm{c}_{\mathrm{HSA}}=50 \mu \mathrm{M}$ koncentrációjú PBS-es 
oldatának bejuttatását követően (a 10. ábra $\mathbf{C}$ részén az első szürke árnyalattal kiemelt szakasz) a szenzorfelület feletti evaneszcens térrészben bekövetkező törésmutató változás révén, a szenzorhoz kapcsolt fotométer segítségével detektált reflektancia görbe minimuma nagyobb $\lambda$ értékek felé tolódik el. Eközben és mérés további szakaszaiban a referencia csatornán továbbra is PBS áramlik keresztül. A 10. ábra B része szemlélteti a reflektancia görbék alakulását a HSA oldattal telített mintakamrának megfelelő állapotban, amely esetén a $\Delta \lambda$ értéke maximális. Ezt követően a mintakamrába PBS kerül bevezetésre, így a szenzorjel csökkenő tendenciát vesz fel, amíg a szenzorfelületről lemosódik a feleslegben jelen lévő (a szenzorfelülethez nem kovalensen kötött) fehérje mennyiség és ennek következtében az alapvonalnál nagyobb $\Delta \lambda$ értéknek megfelelő állandósult állapot jelenik meg. Ez a részlegesen telített szenzorfelületnek megfelelő jel állandósulna a szenzorgramon (10. ábra C része), amennyiben nem kerülne sor a fehérje ismételt injektálására. A fehérje szenzorfelületre ismételt lépésekben történő felvitele és lemosása (a 10. ábra $\mathbf{C}$ részén szürke nyilak jelzik ezeket a lemosási szakaszokat) során rögzített szenzorgram világosan jelzi a szenzorfelület fehérjével történő telítődésének mértékét. A második és harmadik lemosási szakaszt követő állandósult és azonos nagyságú $\Delta \lambda$ érték arra enged következtetni, hogy a szenzorfelület telítetté vált és nem képes több HSA megkötésére.

A telítési értéknek megfelelő szenzorjel $(\Delta \lambda)$, amelyet a 10. ábra $\mathbf{C}$ részén szaggatott vonal jelez felhasználható a fehérje felületegységre vonatkoztatott adszorbeált mennyiségének $\left(m^{s}\right)$ és egyetlen fehérje molekula felületigényének $\left(a_{m}\right)$ meghatározására. A mérések során alkalmazott SPR platform gyártó általi kalibrációjának értelmében a szenzorjel $1 \mathrm{~nm}$-es változása 26,5 $\mathrm{ng} \mathrm{cm}^{-2}$ adszorbeált (vagy kemiszorbeált) felületi rétegnek felel meg [64]. A 10. ábra C részén bemutatott szenzorgram másodlagos y-tengelyén szereplő felületegységre vonatkoztatott adszorbeált tömeg $\left(m^{s}\right)$ változása hozzárendelhető a szenzorjel időbeli változásához. A számított $m^{s}$ értékek azonban a technika sajátságaiból adódóan csak a lemosási szakaszokat követő, állandósult szenzorjelek esetében bírnak fizikai jelentéssel.

A HSA esetében a szenzorfelülethez irreverzibilisen kötött fehérje okozta szenzorjel $(\Delta \lambda)$ változáshoz rendelhető adszorbeált tömeg $m^{s}=64,0 \pm 0,3 \mathrm{ng} \mathrm{cm}^{-2}$ értéknek felel meg, amely a fehérje moláris tömege alapján $\Gamma=9,64 \pm 0,06 \mathrm{nmol} \mathrm{m}^{-2}$ adszorbeált anyagmennyiséget jelent. Feltételezve, hogy a fehérjemolekulák mindegyike közvetlenül a szenzorfelülethez kapcsolódik (monomolekulás adszorpciós réteget alkot) és a HSA molekulák közötti kölcsönhatások révén nem alakul ki másod- vagy harmadlagos 
adszorpciós réteg, a felületegységre vonatkoztatott anyagmennyiség $\left(\Gamma_{\mathrm{m}}\right)^{26}$ ismeretében az egyetlen fehérje által elfoglalt szenzorfelület nagysága az 5.1. egyenlet szerint az Avogadro állandó $\left(N_{A}\right)$ felhasználásával számítható.

$$
a_{m}=\frac{1}{\Gamma_{m} N_{A}}
$$

A monomolekulás borítottságot feltételező számítás alapján egyetlen adszorbeálódott HSA molekula $a_{m}=173 \pm 1 \mathrm{~nm}^{2}$ nagyságú szenzorfelületet foglal el.

A további SPR vizsgálatok során a fentiekben vázolt metodikával analóg módon meghatározásra kerültek BSA és LYZ fehérjék, Cys-Trp és GSH peptidek valamint Cys adszorpciós paraméterei és felületigényeik. Minden esetben $\mathrm{T}=25^{\circ} \mathrm{C}$-on és $50 \mu \mathrm{L}$ perc ${ }^{-1}$ áramlási sebesség beállítása mellett végeztem el a kísérleteket, a BSA és LYZ esetében 30 és $60 \mu \mathrm{M}$ koncentrációjú PBS közegủ oldataik felhasználásával. Az aminosav és a peptidek esetén az alább felsorolt koncentrációjú vizes oldataikat használtam fel a kísérletek során: Cys $(8,0 ; 10 \mathrm{mM})$, Cys-Trp $(6,0 ; 8,0 ; 10,0 \mathrm{mM}), \mathrm{GSH}(4,0 ; 6,0 ; 8,0,10,0 \mathrm{mM})$.

A BSA és LYZ SPR szenzor felületén történő feldúsulását rögzítő szenzorgramok a 11. ábra A és B részén kerülnek bemutatásra.
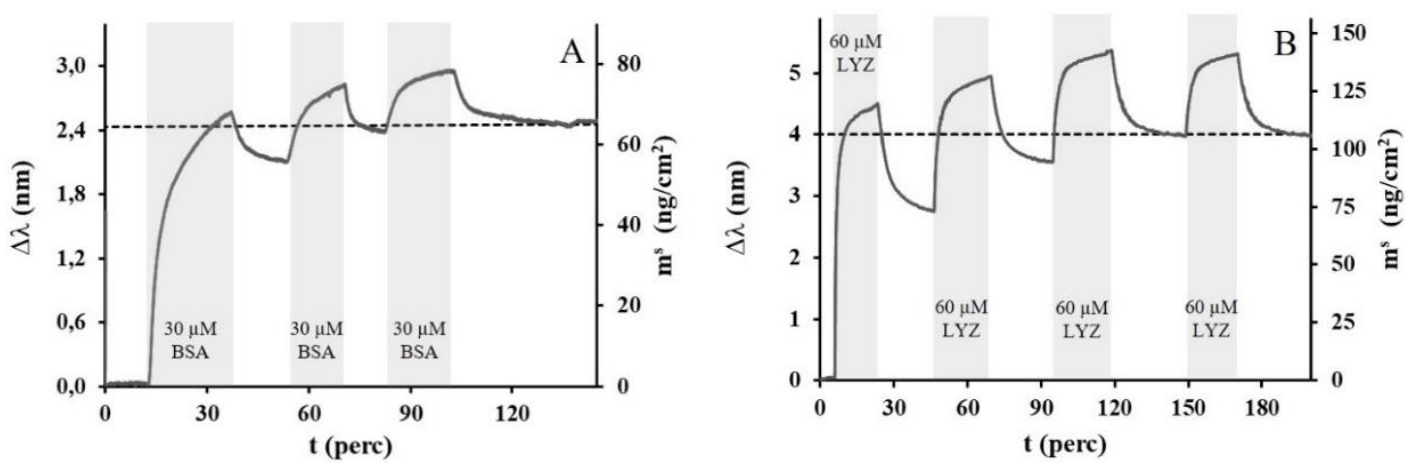

11. ábra: BSA (A) és LYZ (B) fehérjék SPR szenzor arany felületére történő immobilizálása során rögzített szenzorgramok $\left(\mathrm{T}=25^{\circ} \mathrm{C}, q_{v}=50 \mu \mathrm{L}\right.$ perc $^{-1}, \mathrm{c}_{\mathrm{BSA}}=30$

$$
\left.\mu \mathrm{M}, \mathrm{c}_{\mathrm{LYZ}}=60 \mu \mathrm{M}\right)
$$

Az aminosav, valamint a di- és tripeptidek immobilizálása során rögzített szenzorgramokat a 12. ábra $\mathbf{A}, \mathbf{B}$ és $\mathbf{C}$ részéi szemléltetik. A 12. ábra szenzorgramjai mellett feltüntetett sematikus szerkezeti képletek a vizsgált molekulák feltételezett felületi orientációját igyekeznek megjeleníteni, míg az ellipszisek az adott orientációhoz rendelt felületigényt hivatottak szemléltetni.

\footnotetext{
${ }^{26}$ A felületegységre vonatkoztatott anyagmennyiség jelében az „m” index jelöli, hogy az adszorbátum monomolekulás réteget alkot az adszorbens felületén.
} 

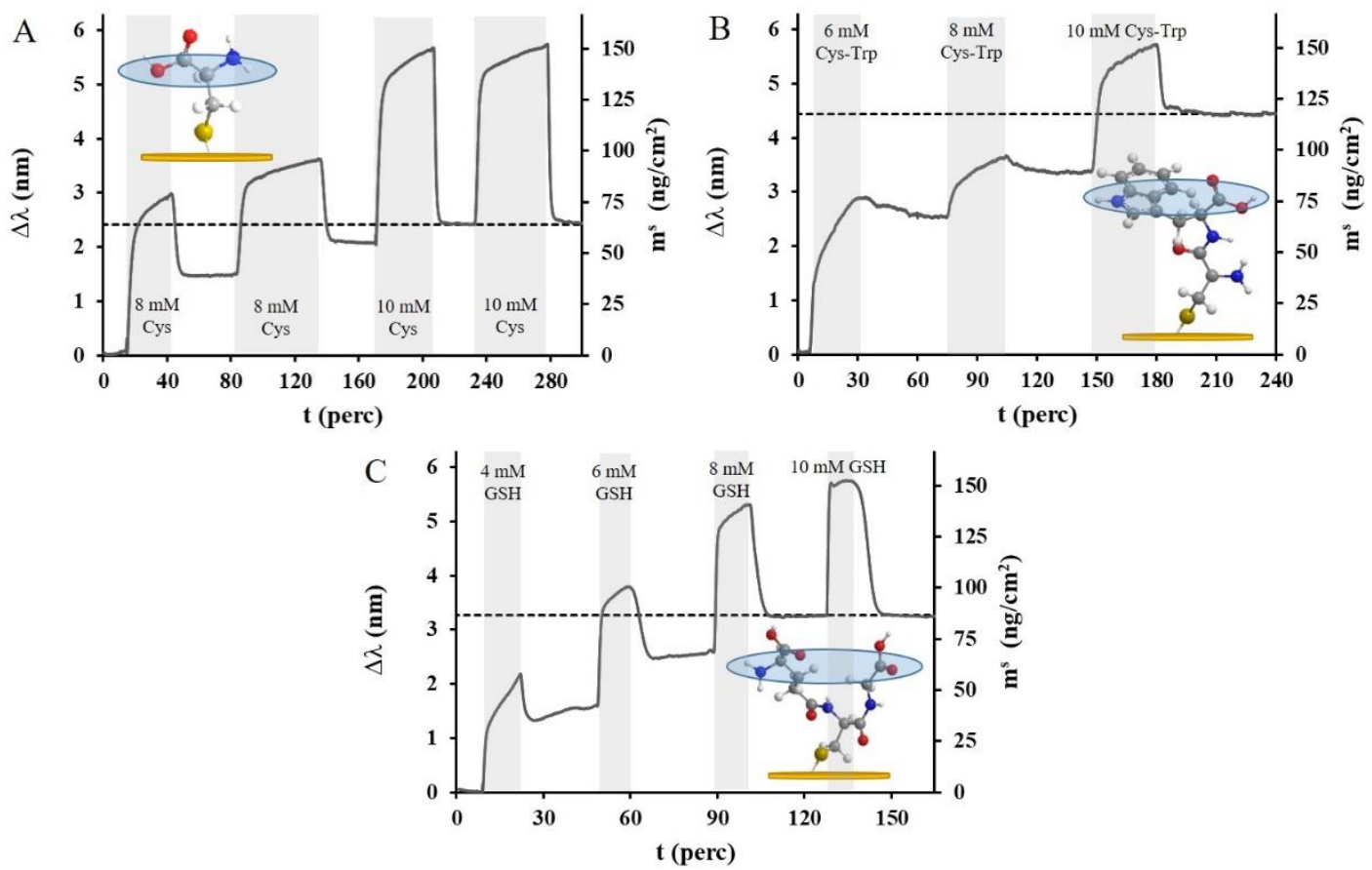

12. ábra: Cys (A), Cys-Trp (B) és GSH (C) molekulák SPR szenzor arany felületére történő immobilizálása során rögzített szenzorgramok $\left(\mathrm{T}=25^{\circ} \mathrm{C}, q_{v}=50 \mu \mathrm{L}\right.$ perc $\left.^{-1}\right)$

A 11. ábra és a 12. ábra által összefoglalt szenzorgramok bizonyítják, hogy a vizsgált fehérjék (BSA, HSA és LYZ) valamint a Cys és Cys-tartalmú peptidek (Cys-Trp, GSH) egyaránt képesek irreverzibilis módon kötődni a szenzor arany felületéhez, így a további kísérletekben alkalmazhatók biomimetikus szilárd -folyadék határfelület kialakítására. Az SPR mérések alapján számított felületigény adatokat kismolekulák esetében az 5.1.2 fejezetben, QCM mérésekkel megerősített adatokkal együtt foglalom össze, míg a fehérjék vonatkozásában az 5.1.3. fejezetben ismertetett $\mathrm{SAXS}^{27}$ méréstechnika eredményeivel vetem össze a megfelelő felületigény adatokat.

\subsubsection{Arany felülethez irreverzibilisen kötödö molekulák immobilizálása QCM szenzor} felületén

Az SPR szenzor alkalmazása során meghatározott adszorpciós mennyiségek és felületigények megerősítése érdekében a Cys és a GSH esetében a vizsgálatokat QCM technika felhasználásával is elvégeztem. Az arany felületéhez várhatóan kovalensen kapcsolódó molekulák felületegységre vonatkoztatott adszorbeált mennyiségének

\footnotetext{
${ }^{27}$ A fehérjék esetében a QCM technika alkalmazása helyett SAXS mérések alapján számított geometriai paramétereket vettem figyelembe, mert elöbbi esetén a Sauerbrey-egyenlet csupán a kismolekulák alkotta adszorpciós réteg által indukált frekvenciaeltolódást írja le helyesen.
} 
meghatározásához az oldószerhez $\left(f_{0}\right)$ és a vizsgált minta ismert koncentrációjú oldatához rendelhetö szenzorjel $\left(f_{\mathrm{i}}\right)$ különbségeként származtatott frekvencia különbséget $(\Delta f)$ használtam fel. Az egyensúlyi szenzorjel megállapításához a mérendő oldatba merülő mérőfej által szolgáltatott frekvencia érték időbeli állandósulását követően jegyeztem fel a $\Delta f$ mértékét, majd a 4.2. egyenlet alapján számítottam az adszorbeált mennyiségeket. A szenzorjel és az $m^{s}$ változását az egyensúlyi koncentráció függvényében ábrázolva készítettem a 13. ábra által bemutatott izotermákat.
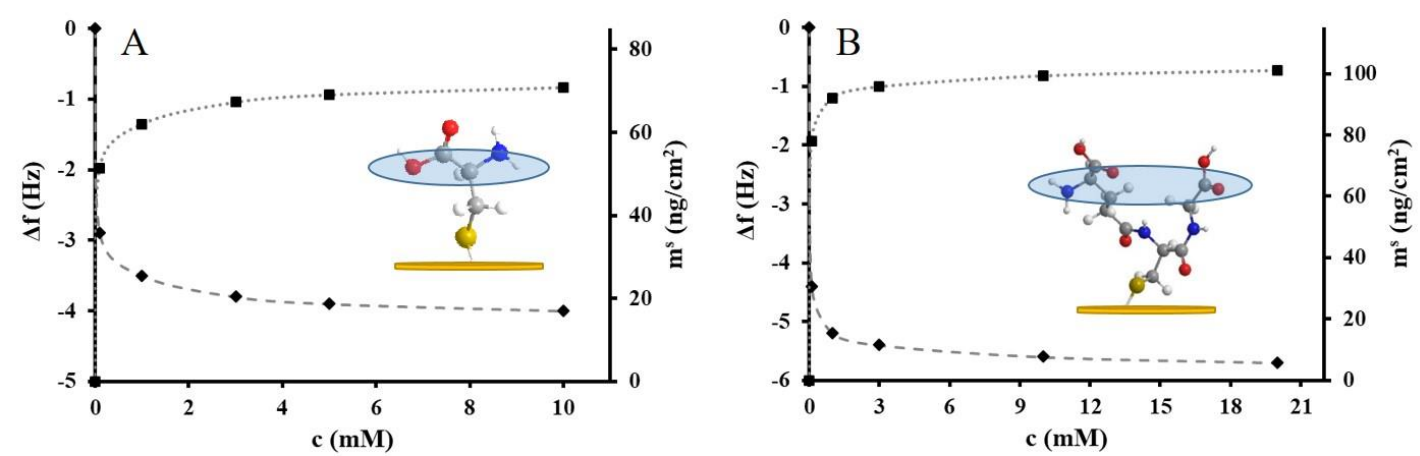

13. ábra: Arany felületen kialakuló Cys (A) és a GSH (B) alkotta monomolekulás rétegek kiépülésének QCM technikával történő vizsgálata során meghatározott $\mathrm{f}=\Delta f(\mathrm{c})$

függvények és izotermák

Az SPR és QCM technikák által meghatározott adszorpciós mennyiségek és felületigények értékeit, valamint ezek sztenderd deviációját az 1. táblázat foglalja össze.

1. táblázat: A Cys, Cys-Trp és GSH SPR és QCM által meghatározott adszorpciós-, és MarvinSketch programmal számított geometriai paraméterei

\begin{tabular}{|c|c|c|c|c|c|c|}
\hline \multicolumn{5}{|c|}{ SPR eredmények } & \multicolumn{2}{|c|}{ MarvinSketch } \\
\hline Molekulák & $\begin{array}{c}\Delta \lambda \\
(\mathrm{nm})\end{array}$ & $\begin{array}{c}\mathrm{m}^{\mathrm{s}} \\
\left(\mathrm{ng} \mathrm{cm}^{-2}\right)\end{array}$ & $\begin{array}{c}\Gamma_{\mathrm{m}} \\
\left(\mu \mathrm{mol} \mathrm{m} \mathrm{m}^{-2}\right)\end{array}$ & $\begin{array}{c}\mathrm{a}_{\mathrm{m}} \\
\left(\mathrm{nm}^{2}\right)\end{array}$ & $\begin{array}{l}\mathrm{a}_{\mathrm{m}, \text { min. }} \\
\text { számított } \\
\left(\mathrm{nm}^{2}\right)\end{array}$ & $\begin{array}{l}\mathrm{a}_{\mathrm{m}, \text { max }} \\
\text { számított } \\
\left(\mathrm{nm}^{2}\right)\end{array}$ \\
\hline Cys & $2,36 \pm 0,03$ & $62,44 \pm 0,89$ & $5,15 \pm 0,10$ & $0,32 \pm 0,03$ & 0,32 & 0,36 \\
\hline Cys-Trp & $4,58 \pm 0,03$ & $121,36 \pm 0,78$ & $3,94 \pm 0,04$ & $0,42 \pm 0,03$ & 0,43 & 0,89 \\
\hline GSH & $3,11 \pm 0,03$ & $82,49 \pm 0,77$ & $2,68 \pm 0,04$ & $0,62 \pm 0,03$ & 0,51 & 0,78 \\
\hline \multicolumn{5}{|c|}{ QCM eredmények } & \multicolumn{2}{|c|}{ MarvinSketch } \\
\hline Molekulák & $\begin{array}{c}\Delta \mathrm{f} \\
(\mathrm{Hz})\end{array}$ & $\begin{array}{c}\mathrm{m}^{\mathrm{s}} \\
\left(\mathrm{ng} \mathrm{cm}^{-2}\right)\end{array}$ & $\begin{array}{c}\Gamma_{\mathrm{m}} \\
\left(\mu \mathrm{mol} \mathrm{m}{ }^{-2}\right)\end{array}$ & $\begin{array}{c}\mathrm{a}_{\mathrm{m}} \\
\left(\mathrm{nm}^{2}\right)\end{array}$ & $\begin{array}{l}\text { am, min. } \\
\text { számított } \\
\left(\mathrm{nm}^{2}\right)\end{array}$ & $\begin{array}{c}\mathrm{a}_{\mathrm{m}, \max } \\
\text { számított } \\
\left(\mathrm{nm}^{2}\right)\end{array}$ \\
\hline Cys & $-4,00 \pm 0,07$ & $70,86 \pm 1,25$ & $5,85 \pm 0,15$ & $0,28 \pm 0,01$ & 0,32 & 0,36 \\
\hline GSH & $-5,65 \pm 0,14$ & $100,98 \pm 2,51$ & $3,28 \pm 0,12$ & $0,51 \pm 0,02$ & 0,51 & 0,78 \\
\hline
\end{tabular}


A méréstechnikák által szolgáltatott szenzorjelek ( $\Delta \lambda$ és $\Delta f$ ) és a szenzorjelek alapján számított paraméterek $\left(m^{s}, \Gamma_{m}\right.$ és $\left.a_{m}\right)$, valamit ezek sztenderd deviációja mellett az 1. táblázat tartalmazza a molekulák minimális $\left(a_{m}\right.$, min. $)$ és maximális $\left(a_{m}\right.$, max. $)$ projekciójának, MarvinSketch nevű szoftver felhasználásával számított értékét. Összehasonlítva az QCM és az SPR mérések alapján becsült felületigény adatokat, megállapítható, hogy a Cys és a GSH esetén az eltérő kísérleti technikák által szolgáltatott eredmények elfogadható egyezést mutatnak. Ezen felül a kísérletileg meghatározott felületigény értékeket a MarvinSketch által számított, minimális projekciós adatok is alátámasztják. Korábban említett okok miatt a CysTrp esetében csak SPR által nyújtott kísérleti adatok állnak rendelkezésre, így csupán SPR mérés erősíti meg, hogy felületi orientáció ezen molekula esetén sokkalta meghatározóbb, mint Cys és GSH esetében.

A kutatócsoportunkban az nanoklaszterek „,zöldkémiai” úton történő előállítását célzó vizsgálatok során munkatársaim a fehérjék mellett aminosavak, ill. di- és tripeptidek aurátionokra gyakorolt hatását tanulmányozták. Janóné Ungor Ditta Anita Ph.D. értekezésében rámutatott, hogy az oldalláncban tiolcsoportot tartalmazó Cys, Cys-Trp és GSH redukáló- és stabilizálószerként egyaránt funkcionálhat a tetrakloro-aurát-ionokkal szemben. Igazolták, hogy a dipeptid felhasználásával előállításra került arany nanoszerkezet a másik két tiolcsoportot tartalmazó molekulától eltérő optikai és szerkezeti tulajdonságokkal rendelkezik. A Cys és GSH vonatkozásában egy önrendeződő, réteges szerkezetü koordinációs polimer [65-67] struktúra kialakulása igazolható, míg a Cys-Trp jelenlétében ez a réteges struktúra nem alakul ki. Az említett réteges struktúra kialakulásának gátja a Trp nagy térkitöltésủ aromás oldalláncának jelenléte, amely pont az arany felületen kialakuló orientáció révén sztérikusan gátolja az önrendeződő szerkezet kiépülését [68].

Az említett vegyületek felületigényének és felületi orientációjának meghatározását célzó SPR és QCM vizsgálatok eredményei, valamint a szoftveres (MarvinSketch) geometriai becslések adatai az említett sztérikusan gát jelenlétét erősítik meg. Az 1. táblázat adatait szemlélve megállapítható, hogy a szenzortechnikák eredményei alapján végzett számítások minden molekula esetében a minimális vetülettel $\left(a_{m}\right.$, min. $)$ azonos nagyságú felületigényt szolgáltnak, ami megerősíti a monomolekulás adszorpciós réteg kialakulását. Továbbá megfigyelhető, hogy a minimális- (ezzel együtt a kísérleti felületigények) és a maximális vetületek aránya a Cys és GSH esetében közel egységnyi, míg a Cys-Trp esetében

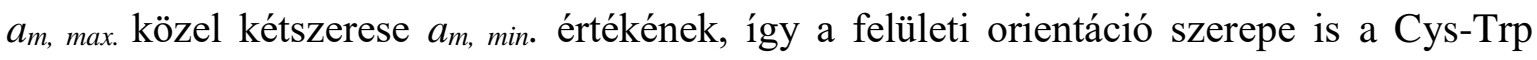
esetében a legmeghatározóbb. A 14. ábra bal oldalán látható a Cys-Trp minimális és maximális vetületét szemléltető kép, amelyet a MarvinSketch nevü szoftverrel generál az 
említett geometriai paraméterek számítása során. A 14. ábra jobb oldalán feltüntetett minimális vetület és a Cys-Trp háromdimenziós szerkezete pedig a sztérikus gát szerepét betöltő aromás oldallánc helyzetét igyekszik szemléletesen ábrázolni.

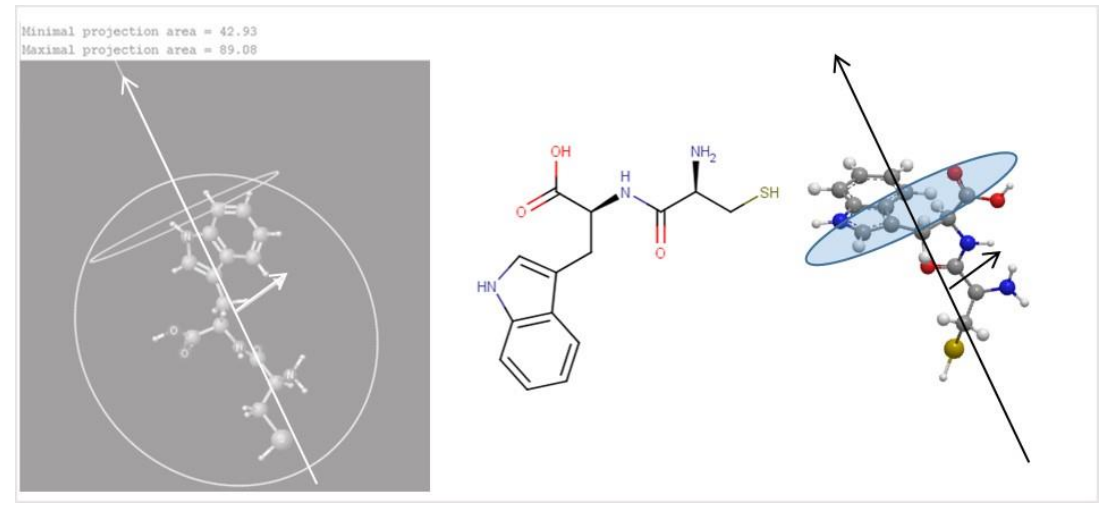

14. ábra: A Cys-Trp MarvinSketch programmal számított minimális- $\left(a_{m, m i n}\right)$ és maximális $\left(a_{m, \max }\right)$ vetületének, és a molekula ezen vetületi síkokhoz viszonyított orientációjának szemléltetése

\subsubsection{Szérum fehérjék és lizozim geometriai jellemzőinek meghatározása SAXS vizsgálatok alapján}

A HSA, BSA és LYS fehérjék SPR technika alkalmazása révén meghatározott felületigényeinek helyességét független mérési eljárásból származó geometriai adatok alapján kívántam megerösíteni. A fehérjék esetében a QCM technika alkalmazása helyett szerencsésebb SAXS mérések szórásgörbéi alapján számított geometriai paramétereket figyelembe venni. A QCM technika esetén, az adszorpciós paraméterek számításához felhasznált Sauerbrey-egyenlet ugyanis a kristály felületén felépülő merev vékonyrétegek által indukált frekvenciaeltolódást írja le helyesen [69]. A fehérjék vagy polimerek által alkotott flexibilis adszorpciós réteg egy önmagában frekvenciafüggő viszkoelasztikus paraméterrel bővített matematikai modell alkalmazást követelné meg [69]. A nem megfelelően megválasztott vagy nehezen becsülhető paramétereket tartalmazó matematikai modell alkalmazása sokszor irreleváns adszorpciós paramétereket eredményezhet. A LYS arany felületen végbemenő adszorpcióját tárgyaló publikációk egyéb okokon felül ezért is nagymértékben eltérö adszorbeált tömegekröl $\left(4-15 \mu \mathrm{g} \mathrm{cm}{ }^{-2}\right)$ számolnak be, ami elfogadhatatlanul alacsony, néhány tized $\mathrm{nm}^{2}$ felületigényt jelent [70,71]. Ezért a várhatóan bizonytalan pontosságú QCM vizsgálatok elvégzése helyett a LYZ és a még nagyobb moláris tömegű szérum fehérjék esetében SAXS vizsgálatokból származó geometriai paraméterekkel kívántam összevetni a vonatkozó SPR mérések eredményeit. 
A SAXS vizsgálatok során a fehérjék PBS közegű oldatai $\left(\mathrm{c}_{\mathrm{BSA}}=3 \mathrm{mg} \mathrm{mL} \mathrm{m}^{-1}, \mathrm{c}_{\mathrm{HSA}}=\right.$ $3 \mathrm{mg} \mathrm{mL}^{-1}, \mathrm{c}_{\mathrm{LYS}}=30 \mathrm{mg} \mathrm{mL}^{-1}$ ) kvarc kapillárisba töltve kerültek a Kratky kamerába integrált mintatartóba, majd a szórási kísérlet a háttérkorrekció érdekében a pufferrel töltött kapillárissal is elvégeztem. A fehérjék puffer háttérrel korrigált szórásgörbéit és ezek alapján a szabad felhasználású SasView nevü szoftver felhasználásával számított párkorrelációs függvényeit a 15. ábra szemlélteti.
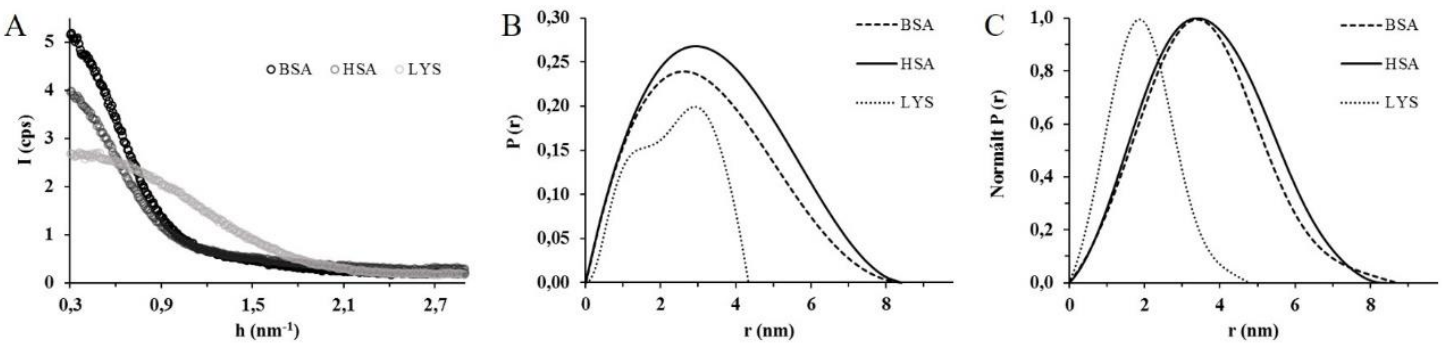

15. ábra: BSA, HSA és LYS fehérjék oldatfázisú SAXS vizsgálata során rögzített szórásgörbék (A) és a szórásgörbék alapján számított párkorrelációs függvények (B), valamint a SASBDB adatbázisból származó párkorrelációs függvények (C)

A párkorrelációs $\mathrm{P}(\mathrm{r})$ függvény megadja azt, hogy egy kiszemelt részecskétől $\mathrm{r}$ távolságra lévő helyen mekkora a részecske előfordulási valószínüsége. A fehérjék $\mathrm{P}(\mathrm{r})$ függvényei alapján tehát könnyedén meghatározható az a maximális kiterjedés $\left(D_{\max }\right)$, amelynek értéke a függvény második zérus helyének x koordinátájával egyezik meg. Az SPR alapú adszorpciós paramétereket és SAXS vizsgálatok alapján származtatott $\left(D_{\max }\right)$ értékeket a 2. táblázat foglalja össze.

2. táblázat: A BSA, HSA és LYZ fehérjék SPR vizsgálat által meghatározott adszorpciós paraméterei és SAXS alapján számított geometriai jellemzői

\begin{tabular}{ccccccc}
\hline \multicolumn{3}{c}{ SPR eredmények } & & \multicolumn{2}{c}{ SAXS eredmény } \\
\hline Molekulák & $\begin{array}{c}\Delta \lambda \\
(\mathrm{nm})\end{array}$ & $\begin{array}{c}\mathrm{m}^{\mathrm{s}} \\
\left(\mathrm{ng} \mathrm{cm}^{-2}\right)\end{array}$ & $\begin{array}{c}\Gamma_{\mathrm{m}} \\
\left(\mathrm{nmol} \mathrm{m}^{-2}\right)\end{array}$ & $\begin{array}{c}\mathrm{a}_{\mathrm{m}} \\
\left(\mathrm{nm}^{2}\right)\end{array}$ & $\begin{array}{c}D_{\max } \\
(\mathrm{nm})\end{array}$ & $\begin{array}{c}\mathrm{A}^{*} \\
\left(\mathrm{~nm}^{2}\right)\end{array}$ \\
\hline BSA & $2,44 \pm 0,03$ & $64,6 \pm 0,8$ & $9,7 \pm 0,2$ & $171,5 \pm 2,9$ & 8,4 & 55,42 \\
HSA & $2,42 \pm 0,01$ & $64,0 \pm 0,3$ & $9,6 \pm 0,1$ & $172,9 \pm 1,2$ & 8,8 & 60,79 \\
LYZ & $4,11 \pm 0,10$ & $108,9 \pm 2,5$ & $76,1 \pm 2,5$ & $21,9 \pm 0,7$ & 4,8 & 18,10 \\
\hline
\end{tabular}

* kör alakú adszorpciós vetületet feltételező, körfelületre számított minimális terület adat

A 15. ábra $C$ részén a saját méréseim eredményei mellett feltüntetésre kerültek a SASBDB ${ }^{28}$ adatbázisból származó P(r) függvények. A Small Angle Scattering Biological Data Bank

\footnotetext{
${ }^{28}$ https://www.sasbdb.org/aboutSASBDB/
} 
(SASBDB) egy szabadon hozzáférhető és kereshető kisszögü szóráskísérleti adatbázis, amely a kísérleti adatok mellett tartalmazza a vonatkozó kísérleti körülményeket, a minta részletes adatait, a felhasznált müszer jellemzőit és a származtatott eredményeket. A fehérjék SASBDB eredetü P(r) függvényei alapján meghatározott $D_{\max }$ értéke a BSA, HSA és LYZ estében rendre 8,7; 8,4 és 4,8 nm értékeknek felelnek meg, így megállapítható, hogy méréseim eredményei az alkalmazott berendezés megkérdőjelezhető teljesítőképességének ${ }^{29}$ ellenére jó egyezést mutatnak az adatbázisban szereplő értékekkel.

Az általam végzett SAXS mérések alapján meghatározott $D_{\max }$ értékekből számított felületigények szintén megtalálhatók a 2. táblázat utolsó oszlopában. Ezeket szemlélve megállapítható, hogy a SPR alapján számított $a_{m}$ értékek a LYZ esetében közel azonosnak tekinthetők a SAXS-alapú felületigénnyel, míg a BSA és a HSA vonatkozásában előbbi közel háromszoros nagyságú $a_{m}$ értéket eredményez ${ }^{30}$. A 16. ábra szemlélteti a BSA és a LYZ eltérő technikák alapján meghatározott geometriai paramétereinek egymáshoz viszonyított arányát.

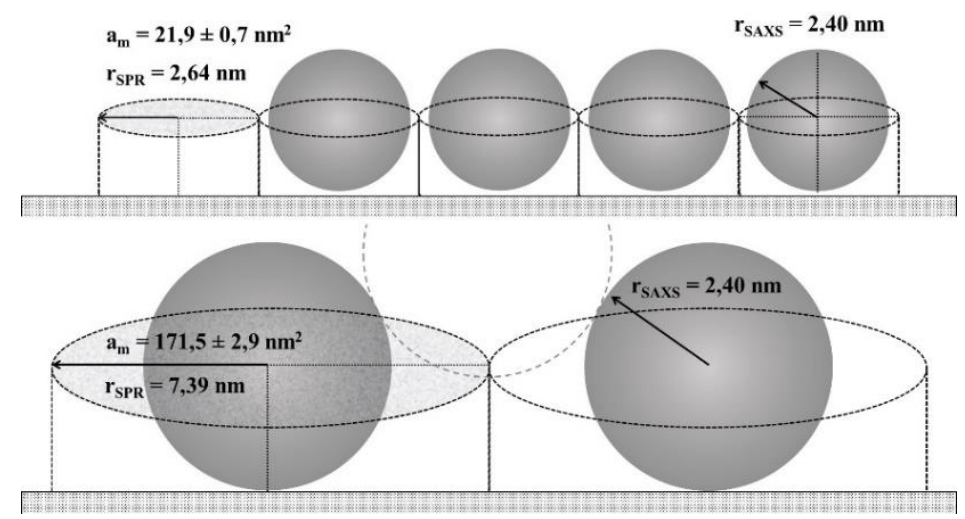

16. ábra: A LYZ (felül) és BSA (alul) fehérjék SPR mérése és oldatfázisú SAXS vizsgálata alapján meghatározott geometriai paramétereinek összehasonlítása

Az arányokat szemléletesen bemutató 16. ábra értelmében, a LYZ esetén mindkét technika alapján szoros illeszkedésü monomolekulás réteg kialakulása feltételezhető, míg a BSA (és a vele közel azonos méretü HSA) esetében az SPR vizsgálat egy kevésbé szoros illeszkedéssel jellemezhető, felület kitöltésü, de ennek ellenére reális adszorpciós rétegmodellt eredményez.

\footnotetext{
${ }^{29}$ A SASBDB kísérleti eredményei jellemzően nagy intenzitású szinkrotron sugárforrás SAXS állomásán kerültek rögzítésre, ami átlagosan egy nagyságrenddel nagyobb jelintenzitást eredményez az általam használt sugárforráshoz képest.

${ }^{30} \mathrm{~A} a_{m}$ értékek összevetésekor az sem hagyható figyelmen kívül, hogy a felületi erök révén, a határfelületen adszorbeált fehérje harmadlagos szerkezete jelentősen eltérhet az oldatfázisban szolvatált formáétól.
} 


\subsection{Fehérje (BSA)-alapú kolloidális gyógyszerhordozó és hatóanyaga (IBU) közötti kölcsönhatás szilárd/folyadék határfelületen kivitelezett modellezése}

Kutatócsoportunkban közel öt éve foglalkozunk olyan gyógyszerhatóanyag-tartalmú kompozitok előállításával és jellemzésével, ahol polimerek, szervetlen hordozók és többek között szérum fehérjék alkalmazhatóságát tanulmányozzuk bizonyos célvegyület(ek) (főként neuroaktív és nem-szteroid gyulladáscsökkentő molekulák) időben szabályozott leadásának ill. a vegyületek célzott helyre történő szállításának megvalósításához [72-76]. Az egyik ilyen, korábban Dr. Varga Noémi (SZTE TTIK FKAT) által előállított és karakterizált kompozit rendszer [77] szilárd/folyadék határfelületen történő modellezését végeztem el SPR méréstechnika révén. A kompozit előállítása során $20 \mathrm{~m} / \mathrm{V} \%$ koncentrációjú CPS közegü $(\mathrm{pH}=3,0)$ BSA-oldathoz adagolták folyamatos kevertetés közben a hatóanyag pufferes oldatát 1:1 és 1:10 BSA:IBU mólarány beállítása mellett, majd $\mathrm{c}=2,0 \mathrm{M}$ koncentrációjú $\mathrm{Na}_{2} \mathrm{~S}_{4}$ oldat hozzáadása által történt meg BSA/IBU kompozit részecskék kicsapása, amelyek centrifugálás után kerültek fagyasztva szárításra. A 17. ábra szemlélteti a PBS pufferbe diszpergált 1:10 BSA/IBU mólarányú kompozit karakterizálása során készített dinamikus fényszórás (DLS)-alapú méreteloszlás és SAXS vizsgálat szórásgörbéje alapján számított párkorrelációs görbéket és a transzmissziós elektronmikroszkóp (TEM) segítségével készült képet.
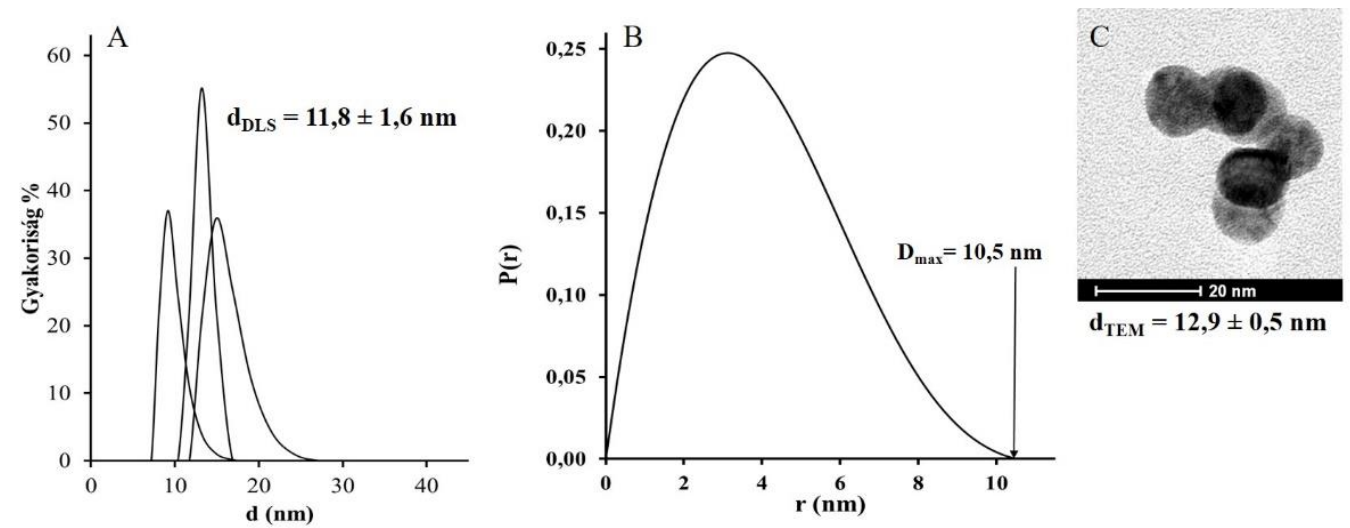

17. ábra: Neutrális kémhatású pufferbe $(\mathrm{pH}=7,4$; $\mathrm{PBS})$ diszpergált BSA/IBU kompozit részecskék méreteloszlás $(\mathrm{A})$ és párkorrelációs $(\mathrm{B})$ görbéi valamit a beszárított mintáról készült reprezentatív TEM felvétel [77]

PhD munkám során a fenn említett BSA-alapú kolloidális gyógyszerhordozó és IBU hatóanyaga közötti kölcsönhatás SPR szenzorfelületen kivitelezett modellezését végeztem el, mely során a vizsgálatok szobahőmérsékleten történtek a fehérje és az IBU puffer közegü oldatainak felhasználásával. Első lépésben a szenzorfelület funkcionalizálása az 5.1.1. 
fejezetben ismertetett módon történt az alábbi paraméterek alkalmazása mellett: $\mathrm{T}=20{ }^{\circ} \mathrm{C}$, $q_{v}=25 \mu \mathrm{L}$ perc $^{-1}$ és $\mathrm{c}_{\mathrm{BSA}}=50 \mu \mathrm{M}$. A fehérje és a szenzorfelület közötti irreverzibilis kötés kialakulása minden valószínűség szerint a fehérje cisztein aminosav alegységének tiolcsoporja révén valósulhatott meg, a tiolcsoport kén donorja és az arany felületet alkotó atomok között kovalens kötés kialakulása által.

A szenzorfelület funkcionalizálását követően savas $(\mathrm{pH}=3,0 ; \mathrm{CPS})$ és neutrális ( $\mathrm{pH}$ = 7,4; PBS) közegben oldott IBU mintákat áramoltattunk a szenzor felület felett, így a hatóanyag és a fehérje közötti kölcsönhatást jellemző szenzorgramok rögzítése is megtörténhetett. Az IBU kötődésének tanulmányozásához mindkét pH-n $\mathrm{c}_{\mathrm{IBU}}=5,0 ; 10,0$; 20,0; és 30,0 $\mu \mathrm{M}$ koncentrációjú hatóanyag-oldatokat használtunk fel. A szenzorfelület funkcionalizálását és az IBU fehérjével borított szenzorfelületen végbemenő megkötődését jellemző szenzorgramok rögzítését Dr. Csapó Edit és Dr. Sebők Dániel (SZTE TTIK FKAT) kivitelezte, míg a dolgozatban bemutatott szenzorgramok kiértékelését $\mathrm{PhD}$ munkám keretében magam végeztem.

\subsubsection{A gyógyszerhordozó SAXS, ITC és SPR technikák általi jellemzése}

A kolloidális gyógyszerhordozó SPR szenzorfelületen kivitelezett modellezése során az eltérő kémhatású oldószeres környezetnek a hatóanyag megkötődésre és felszabadulásra gyakorolt hatását igyekeztünk kvantitatív módon jellemezni, és összevetni a már rendelkezésre álló független SAXS és ITC vizsgálatok kísérleti eredményeivel. A független mérések főbb eredményeit, a könnyebb összevethetőség érdekében, ezen fejezet elején röviden összefoglalom. A gyógyszerhordozó szerkezetének jellemzése érdekében végzett SAXS vizsgálatok eredményei ${ }^{31}$ arra engedtek következtetni, hogy a savas $(\mathrm{pH}=3,0)$ kémiai környezet révén kigombolyodott ${ }^{32}$ (nyíltabb) fehérje szerkezet van jelen az oldat fázisban, ahogyan azt a 18. ábra A részén bemutatott Kratky reprezentáció is szemlélteti. A SAXS eredmények alapján savas környezetben a BSA ún. unfolded szerkezete igazolható, mely a kötőhelyek jobb hozzáférhetősége miatt, nagyobb affinitással képes jelentősebb mennyiségü IBU megkötésére, mint a neutrális kémhatású PBS pufferben szolvatált formája, ahol a kevésbé kigombolyodott, natív állapot a jellemző szerkezet.

\footnotetext{
${ }^{31}$ A BSA-alapú gyógyszerhordozó szerkezetét leíró szórásgörbék kiértékelését Dr. Sebők Dániel végezte el.

${ }^{32}$ A másodlagos szerkezet nélküli konformációk sokaságát és a natívhoz képest nagyon kevés másodlagos szerkezeti elemet tartalmazó konformációkat, a fehérje denaturált, vagy kitekeredett (,unfolded”) állapotának nevezik.
} 

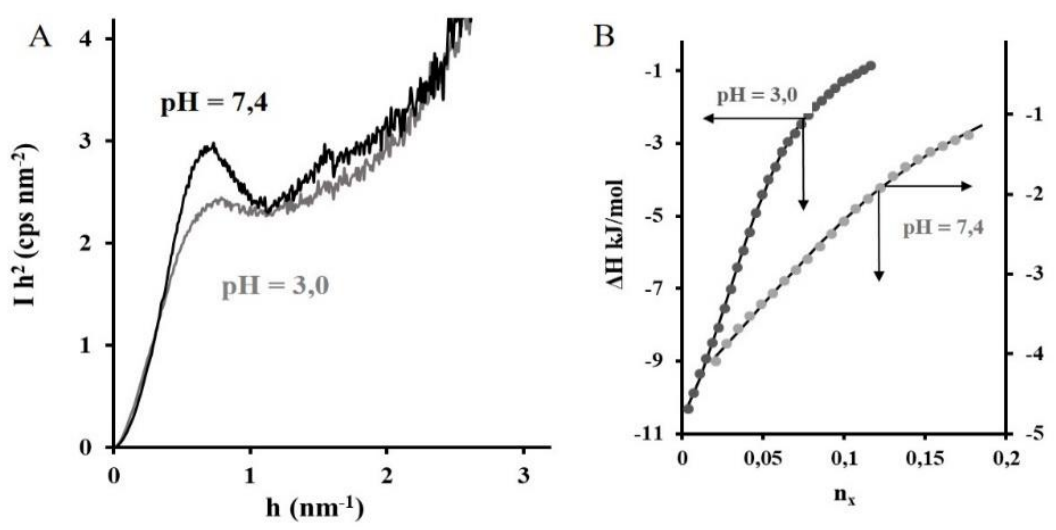

18. ábra: A gyógyszerhordozó neutrális és savas közegben kivitelezett SAXS vizsgálatának Kratky reprezentációi (A) és a BSA-IBU mikrokalorimetriás titrálása során rögzített (diszkrét pontok) és modellillesztés útján generált (folytonos vonalak) entalpogramok $\mathrm{pH}=3,0$ és $\mathrm{pH}=7,4$ esetén (B)

A fehérje eltérő szerkezetének a hatóanyag megkötődésére gyakorolt hatását a Dr. Varga Viktória (SZTE TTIK FKAT) által kivitelezett és kiértékelt ITC mérések útján is sikerült igazolni. A kalorimetriás vizsgálatok során pufferben oldott $\mathrm{c}_{\mathrm{BSA}}=50 \mu \mathrm{M}$ koncentrációjú BSA- oldathoz került hozzáadagolásra a $30 \mu \mathrm{M}(\mathrm{pH}=3,0)$ és $40 \mu \mathrm{M}(\mathrm{pH}=$ 7,4) koncentrációjú, szintén puffer közegü IBU oldata $10 \mu$ L-es adagokban, állandó kevertetés mellett. A szobahőmérsékelten $\left(25^{\circ} \mathrm{C}\right)$ regisztrált entalpogramok egyetlen kötőhelyet feltételező modellel (MicroCal ITC Origin Analysis szoftver) történő illesztése (18. ábra $\mathbf{B}$ része) által származtatott egyensúlyi állandó $\left(K_{A}\right)$, kötési sztöchiometria $\left(n_{x}\right)$ és entalpiaváltozás $(\Delta H)$ értékek alakulása szintén arra enged következtetni, hogy fehérje savas kémhatású pufferes oldatában $\left(K_{A}=3,62 \times 10^{3} \pm 0,01 \times 10^{3} \mathrm{dm}^{3} \mathrm{~mol}^{-1} ; n_{x}=22,1 \pm 0,1 ; \Delta H\right.$ $=-22,85 \pm 0,57 \mathrm{~kJ} \mathrm{~mol}^{-1}$ ) nagyobb affinitással és közel kétszeres mennyiségü hatóanyagot képes megkötni, mint neutrális közegü $\left(K_{A}=2,47 \times 10^{3} \pm 5,33 \times 10^{1} \mathrm{dm}^{3} \mathrm{~mol}^{-1} ; n_{x}=8,8 \pm\right.$ 0,$\left.1 ; \Delta H=-19,36 \pm 0,05 \mathrm{~kJ} \mathrm{~mol}^{-1}\right)$ natív formája.

Mindezen megállapítások helytállóságát a vonatkozó SPR vizsgálatok eredményeinek összevetése által is sikerült megerősíteni. A 19. ábra szenzorgramjait szemlélve megfigyelhető, hogy a míg neutrális kémhatású oldószeres környezetben a hatóanyag megkötődése reverzibilis (19. ábra $\mathbf{A}$ része), a savas kémhatású oldószerből, megfelelő koncentráció viszonyok esetén az IBU irreverzibilisen (19. ábra B része) kötődik a hordozóhoz. Az irreverzibilisen kötött IBU jelenlétét igazolja, hogy a 19. ábra B részén, a $20 \mu \mathrm{M}$ koncentrációjú hatóanyag injektálását (szürke háttérrel jelzett régió) követő 
lemosási szakasz végén a korábbi alapvonalnál nagyobb állandósult érték figyelhető meg, amit az ábrán a dupla nyíl jelöl.
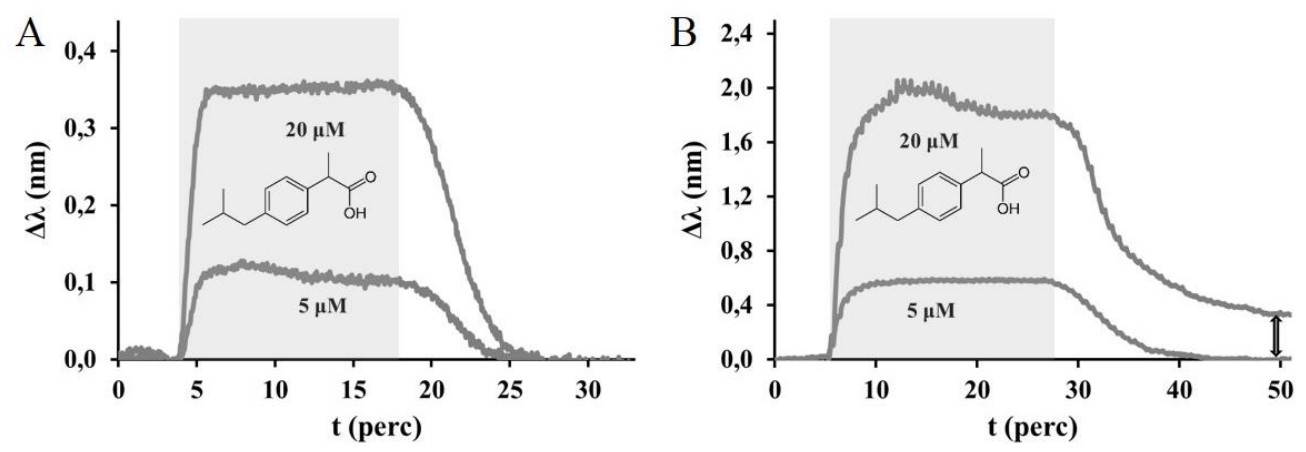

19. ábra: $B S A$-alapú kolloidális gyógyszerhordozó és hatóanyaga (IBU, $\mathrm{c}_{\mathrm{IBU}}=5$ és 20 $\mu \mathrm{M})$ közötti kölcsönhatás SPR-alapú modellezése során neutrális $(\mathrm{A}: \mathrm{pH}=7,4)$ és savas (B: $\mathrm{pH}=3,0)$ közegben rögzített szenzorgramok

Az alacsonyabb pH érték alkalmazása esetén tapasztalt irreverzibilis kötési folyamat rendkívül előnyös a kolloidális gyógyszerhordozó előállítása során, de nagymértékben korlátozza az SPR eredmények feldolgozásának lehetőségét. Az állandósult állapotok (kvázi egyensúly) alapján elvégezhető adszorpció megközelítésű kiértékelést és a szenzorgramok kinetikai modellel történő illesztését követő számítási eljárásokat egyaránt megnehezíti az irreverzibilisen kötődő hatóanyag jelentléte. Annak érdekében, hogy az ebből adódó számítási nehézségeket elkerüljem, csak a neutrális környezetben rögzített szenzorgram sorozat értékelését végeztem el a következő 5.2.2 fejezetben részletezett megfontolások alapján kidolgozott kiértékelési eljárásnak megfelelően.

\subsubsection{A hatóanyag szilárd/folyadék határfelületen végbemenö megkötödését jellemzö} sebességi állandók meghatározása az SPR szenzorgramok illesztésével

Amennyiben a hatóanyag (IBU) és a szenzor felületen immobilizált partner (BSA) kapcsolódása révén kialakuló felületi komplex kialakulását egy teljes mértékben reverzibilis bimolekulás reakcióként értelmezzük, az alábbi 5.2. reakcióegyenlet írja le a kötési komplex keletkezését és bomlását:

$$
\mathrm{A}+\mathrm{B} \leftrightarrow \mathrm{AB}
$$

ahol A (a szenzorfelület felett áramló pufferben oldott ligandum jellegü molekula) és B (a szenzorfelületen rögzített receptor jellegü molekula) a két kölcsönható molekula, AB pedig a felületi komplex. A felületi komplex kialakulásához (asszociációjához) és annak disszociációjához rendre $k_{a}$ és $k_{d}$ asszociációs és disszociációs sebességi állandók 
rendelhetök. Feltételezve, hogy az asszociáció elsőrendü mindkét reaktánsra nézve és a disszociáció elsőrendü, az átmeneti komplex koncentrációjának időbeli változását leíró 5.3. sebességi egyenlet az alábbi formában írható fel:

$$
\frac{d[A B]}{d t}=k_{a}[A][B]-k_{d}[A B]
$$

A SPR szenzor mérési elrendezésének és a mérések kivitelezési módjának következtében a funkcionalizált szenzor felület feletti térrészben az oldott anyag (analit) koncentrációja állandó a folytonos betáplálás következtében. Ezáltal az analit koncentrációja $[\mathrm{A}] \mathrm{a}$ betáplálás minden időpillanatában megegyezik annak kezdeti (bemérési) koncentrációjával $[\mathrm{A}]=[\mathrm{A}]_{0}$. Az immobilizált reakciópartner $[\mathrm{B}]_{0}$ kezdeti koncentrációja pedig a felülethez kötött szabad [B] és szintén felületre kötött, de komplex formában [AB] jelenlévő speciesek koncentrációinak összegével $[\mathrm{B}]_{0}=[\mathrm{B}]+[\mathrm{AB}]$ definiálható. A komplex forma koncentrációja ezáltal az immobilizált partner kiindulási koncentrációjának és a felülethez kötött szabad receptor jellegü molekula koncentrációjának különbségeként adható meg [AB] $=[\mathrm{B}]_{0}-[\mathrm{B}]$. Mindezeket felhasználva és behelyettesítve az átmeneti komplex koncentrációjának időbeli változását leíró 5.3. sebességi egyenletbe a következő 5.4 . sebességi egyenlethez jutunk.

$$
\frac{d[A B]}{d t}=k_{a}[A]_{0}[B]-k_{d}\left([B]_{0}-[B]\right)
$$

A szenzor felületén kialakuló átmeneti komplex koncentrációjának időbeli változását leíró 5.4. sebességi egyenlet átrendezés után az alábbi 5.5. formában írható fel:

$$
\frac{d[A B]}{d t}=[B]\left(k_{a}[A]_{0}+k_{d}\right)-k_{d}[B]_{0}
$$

Az 5.5. összefüggést szemlélve látható, hogy a felülethez kötött szabad receptor koncentrációjának ([B]) kiemelése révén a zárójeles tag magába foglal egy látszólagos sebességi állandót $\left(k_{o b s}\right)$ definiáló összeget, amelyek által $k_{o b s}$ lineáris koncentrációfüggése az 5.6. egyenlet formájába írható le.

$$
k_{o b s}=k_{a}[A]_{0}+k_{d}
$$

Feltételezve, hogy a szenzor felületén kialakuló AB komplex képződése kedvezményezett $\left(k_{a} \gg k_{d}\right)$, a koncentrációjának időbeli változását leíró 5.5. sebességi egyenletből az utolsó $\mathrm{k}_{\mathrm{d}}[\mathrm{B}]_{0}$ tag elhanyagolható, így a szenzor felületén kialakuló komplex koncentrációjának időbeli változását leíró formula az 5.7. egyenlettel leírt egyszerü alakban határozható meg.

$$
\frac{d[A B]}{d t}=k_{o b s}[B]
$$


A reakcióban résztvevő reaktánsok és a termék koncentrációjának időbeli változását meghatározó sebességi egyenleteket tekintve az alábbi 5.8. összefüggés láncolat írható fel.

$$
\frac{d[A B]}{d t}=-\frac{d[A]}{d t}=-\frac{d[B]}{d t}
$$

Az 5.8. összefüggést figyelembe véve az immobilizált fehérje és vele kölcsönható hatóanyag asszociációja során a szabad fehérje (felületi kötőhelyek) koncentrációjának csökkenését leíró sebességi egyenlet az alábbi 5.9. forma szerint adható meg.

$$
\frac{d[B]}{d t}=-k_{o b s}[B]_{0}
$$

Az 5.9. alakú differenciális sebességi egyenlet azért kitüntetett fontosságú, mert átrendezés és a Newton-Leibniz-formula alábbiak szerinti, [B] és $[B]_{0}$ valamint t és 0 határok közötti alkalmazása révén

$$
\int_{\left[B_{0}\right]}^{[B]} \frac{d[B]}{[B]}=-\int_{0}^{t} k_{o b s} d t
$$

megadható az 5.9. differenciálegyenlet 5.10. alakú analitikus megoldása, ami a szabad receptor, jelen esetben a BSA koncentrációjának csökkenését írja le.

$$
[B]=[B]_{0} e^{-k_{o b s} t}
$$

Amennyiben az 5.10. integrált sebességi egyenlet szerint csökken a szabad fehérje koncentrációja az 5.8. összefüggést figyelembe véve az $\mathrm{AB}$ felületi komplex (az immobilizált fehérje és a hatóanyag kapcsolódásával létrejövő speciesz) koncentrációjának pszeudo-elsőrendủ növekedését az alábbi 5.11. integrált sebességi egyenlet határozza meg.

$$
[A B]=[B]_{0}\left(1-e^{-k_{o b s} t}\right)
$$

A vizsgálataim során alkalmazott mérési elrendezést és a szenzorjel létrejöttének módját figyelembe véve megállapíthatjuk, hogy a hullámhossz-eltolódás $(\Delta \lambda)$ mértéke egy adott időpillanatban valamely $\alpha$ arányossági tényező szerint arányos az $\mathrm{AB}$ komplex adott időpillanatban mérhető koncentrációjával [78-80].

$$
\Delta \lambda=\alpha[A B]
$$

Továbbá az is belátható, hogy egy adott koncnetrációjú ligandum oldat szenzorfelületre történő injektálása során a mérhető maximális jelintenzitás $\left(\Delta \lambda_{\max }\right)$ a felületi komplex 
maximális koncentrációjával ([AB] $\left.]_{\max }\right)$ és ezáltal az immobilizált reakciópartner $[\mathrm{B}]_{0}$ kezdeti koncentrációjával lesz arányos az 5.12 összefüggés alapján.

$$
\Delta \lambda_{\max }=\alpha\left[A B_{\max }\right]=\alpha[B]_{0}
$$

$\mathrm{Az}$ felsorolt arányosságokat figyelembe és alkalmazva, az $\alpha$ arányossági tényező számértékének ismerete és minden további kalibráció nélkül megalkotható szenzorjel időbeni változását leíró 5.13. összefüggés, amely egyben az AB komplex koncentrációjának pszeudo-elsőrendü növekedését leíró integrált sebességi egyenlet.

$$
\Delta \lambda=\Delta \lambda_{\max }\left(1-e^{-k_{o b s} t}\right)
$$

Az 5.14. integrált sebességi egyenletet szemlélve megállapítható, hogy a kísérleti adatok (szenzorgram) illesztése által az összefüggés lehetőséget teremt $k_{o b s}$ és $\Delta \lambda_{\text {max }}$ értékének maghatározására.

A méréseim során alkalmazott SPR szenzor adatrögzítő szoftvere lehetőséget ad az adatok szövegfájlok ${ }^{33}$ formájában történő kinyerésére. Az adatfájlok az idő függvényében rögzített és korrigált szenzorjel értékét tartalmazzák a három másodperces időbeli felbontásban, így egy órán keresztül rögzített vizsgálat kiértékelése során 1200 adatpár kezelését kell megoldani, ami speciális kiértékelö program hiányában táblázatkezelő szoftverek használatával oldható meg. A 20. ábra A részén látható a mentett szövegfájl adatainak ábrázolásával készített szenzorgram, ahol szürke háttér jelöli a növekvő koncentrációjú IBU oldatok szenzorfelületre juttatásának periódusait, amiket minden esetben pufferes lemosási fázis követ.

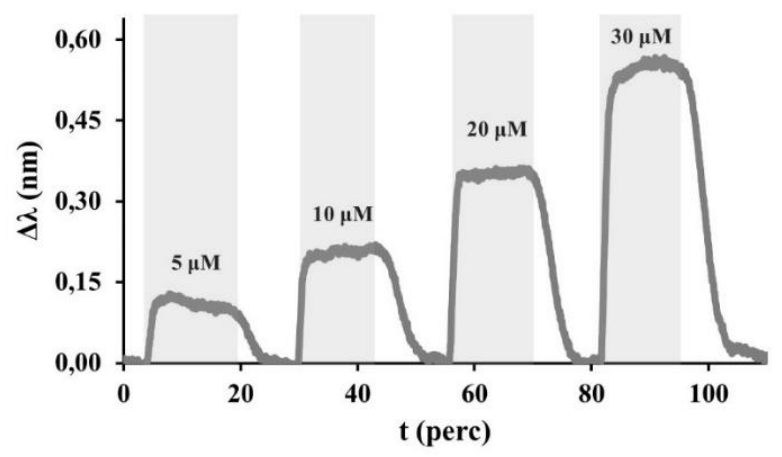

20. ábra: BSA és IBU ( $\mathrm{c}_{\mathrm{IBU}}=5,10,20$ és $\left.30 \mu \mathrm{M} ; \mathrm{pH}=7,4(\mathrm{PBS}) ; q_{v}=50 \mu \mathrm{L} \mathrm{perc}^{-1}\right)$ közötti kölcsönhatás SPR-alapú modellezése során rögzített szenzorgram

\footnotetext{
${ }^{33}$ ASCII karakterkészletet alkalmazó .txt kiterjesztésű szöges dokumentumok.
} 
A szenzorgramok 5.14. egyenlet alapján történő modellezéséhez elsőként az időskálán kell egységesíteni a különböző koncentrációjú analit oldatok injektálása során rögzített kísérleti görbéket. A kinetikai modell $\mathrm{t}=0$ időpillanata, vagyis a szenzorfelületen kialakuló $\mathrm{AB}$ kötési komplex keletkezésének kezdete, az injektálásnak azon pillanatával egyezik meg, amikor a ligandum oldata eléri a mintakamrát. Egyetlen jelsorozat kiértékelése során célszerü a kísérleti adatok időskáláját úgy módosítani, hogy a kísérleti adatsor és modell azonos $\mathrm{t}=0$ időpillanatból induljon (21. ábra). A 21. ábra A és $\mathbf{B}$ része egyazon virtuális kísérleti adatsor nemlineáris paraméterbecslés útján történő illesztését mutatja. A szürke folytonos vonallal szimbolizált modellgörbe adatpontjait az 5.14. egyenlet alapján számíthatjuk tetszőleges kezdeti paraméterkészlet (a 21. ábra A részén: $\Delta \lambda_{\max }=0,450 \mathrm{~nm}$ és $k_{o b s}=0,130$ $\left.\mathrm{s}^{-1}\right)$ megadásával. Miután minden kísérleti adat $\left(\Delta \lambda_{\text {mért }}\right)$ mellé egy kalkulált érték $\left(\Delta \lambda_{\text {számitott }}\right)$ rendelhető, akkor a valós- és a modell adatok közötti eltérés számszerűsíthető, és az eltérés mértéke a különbség négyzetre emelésével pozitívvá tehető.
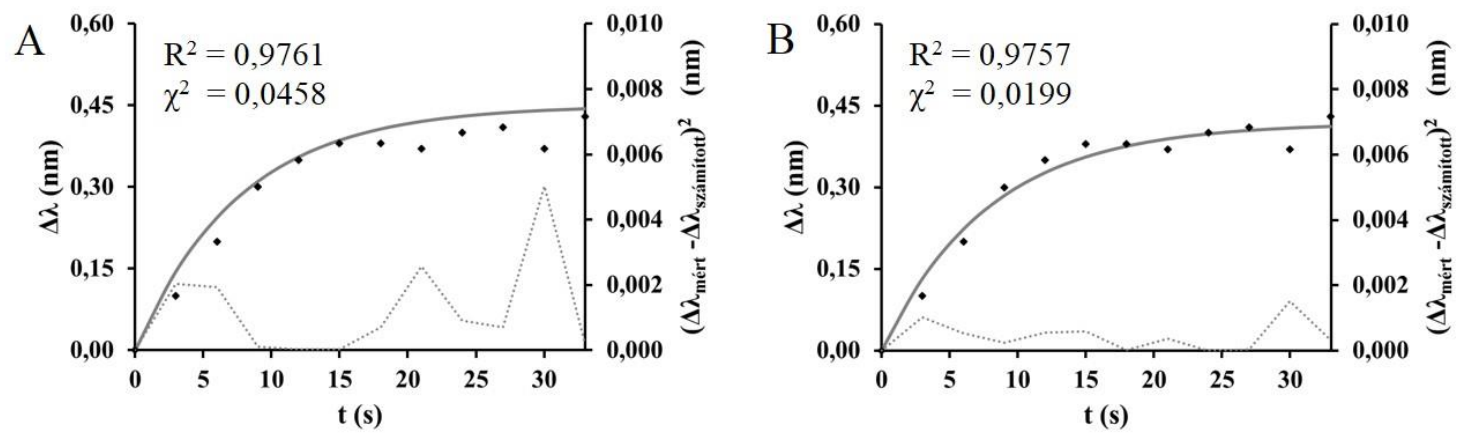

21. ábra: A szenzorgram pszeudo-elsőrendű integrált sebességi egyenlettel történő, nemlineáris paraméterbecslés alapú illesztésének szemléltetése A: tetszőlegesen választott kiindulási paraméterkészlet esetén B: a nemlineáris becslés által meghatározott paraméterkészlettel

A 21. ábra grafikonjain az eltérés négyzetek értéke a másodlagos y-tengelyen került feltüntetésre. Az eltérés négyzetösszeg, amelyet a 21. ábra $\mathbf{A}$ és $\mathbf{B}$ részén egyaránt a szürke pontozott vonal alatti terület nagysága határoz meg, egy olyan egyetlen számértékkel jellemezhető célérték, amely minimalizálásával lehetőség adódik a legjobb modellillesztés paraméterkészletének ( $\Delta \lambda_{\max }$ és $\left.k_{o b s}\right)$ meghatározására. Az eltérés négyzetösszeg tetszőleges kiindulási paraméterkészlet variálása melletti minimalizálása megoldható a Microsoft Excel egy táblázatkezelő program Solver [81] nevü bővítményének használatával, amely a 21. ábra $\mathbf{B}$ részén szereplő illesztést eredményezi. A 21. ábra B részén szemmel látható, hogy a paraméterbecslési eljárást követően javul az illesztés és ezzel együtt csökken a szürke 
pontozott vonal alatti terület nagysága. A modellillesztés jóságának minősítésére általánosan használt determinációs együttható $\left(\mathrm{R}^{2}\right)$ és a nemlineáris paraméterbecslésben gyakrabban alkalmazott khi négyzet próba $^{34}\left(\chi^{2}\right)$ eredménye is azt jelzi, hogy modell az új paraméterkészlettel (a 21. ábra B részén: $\Delta \lambda_{\max }=0,418 \mathrm{~nm}$ és $k_{o b s}=0,127 \mathrm{~s}^{-1}$ ) helyesebben írja le a kísérleti adatokat. A szenzorgramok kinetikai modellel történő illesztése során természetesen alkalmazható olyan időtengely is, amelyen a $t=0$ időpillanat a vizsgált ligandum jellegü vegyület áramló mintaadagoló rendszerbe történő bejuttatása, így a szenzorfelület elérése azonos időintervallum eltelte után következik be minden alkalmazott ligandum koncentráció esetén. Ebben az esetben csak a modellgörbék x-tengelyét kell megfelelően eltolni, ahogyan a 22. ábra A részén látható. Amennyiben a nem-lineáris paraméterbecslés után rendelkezésre állnak a $k_{o b s}$ értékek, ezeket a ligandum koncentrációjának függvényében ábrázolva, olyan adatsorhoz jutunk, amelynek az 5.6. egyenlet alapján végzett lineáris regressziója által a valós sebességi állandók értéke számítható.
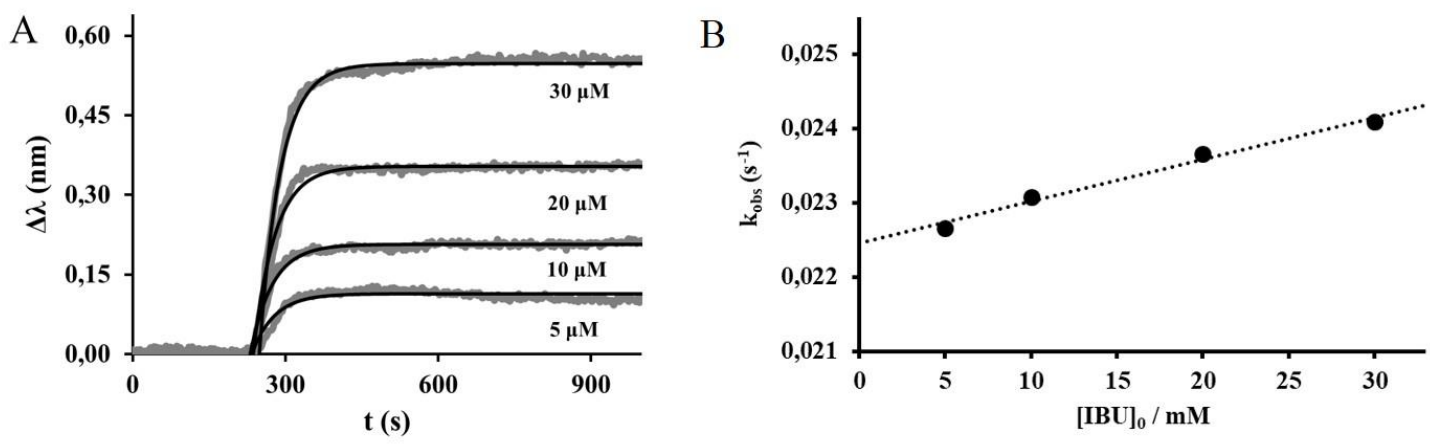

22. ábra: BSA és IBU közötti kölcsönhatás egyideüsített szenzorgramjai (szürke) a szenzorgramok 5.13. egyenlet alapján generált (fekete) modellgörbéivel (A) és a látszólagos sebességi állandók koncentrációfüggése (B)

A 22. ábra B részén feltüntetett egyenes illesztése után az egyenes meredeksége $k_{a}=56,4 \pm$ $4,4 \mathrm{dm}^{3} \mathrm{~mol}^{-1} \mathrm{~s}^{-1}$ és tengelymetszete $k_{d}=0,022 \pm 0,019 \mathrm{~s}^{-1}$ sebességi állandó értékeket szolgáltat. A valós sebességi állandók ismeretében azok hányadosából az adott mérési hőmérsékletre vonatkozó egyensúlyi állandó értéke is számítható, amely a fehérje alapú gyógyszerhordozó és hatóanyaga közötti kötés jellegü kölcsönhatás tekintetében $K_{A}=2,51$ $\times 10^{3} \pm 2,00 \times 10^{2} \mathrm{dm}^{3} \mathrm{~mol}^{-1}$ értéknek felel meg. A szilárd/folyadék határfelületen

\footnotetext{
${ }^{34}$ A khi négyzet próba két minőségi változó közötti kapcsolat elemzésére alkalmazható statisztikai próba. A szenzorgramok modellillesztésének minösítése során a $\chi^{2}=\sum \frac{\left(\Delta \lambda_{\text {mért }}-\Delta \lambda_{\text {számított }}\right)^{2}}{\Delta \lambda_{\text {számított }}}$ összefüggés alapján került meghatározásra a számértéke.
} 
kivitelezett SPR-alapú és a kinetikai megközelítést alkalmazó kiértékelés eredménye meglepően jó, összehasonlítva az oldatfázisú és egyensúlyi ITC vizsgálat analóg eredményével $\left(K_{A}=2,47 \times 10^{3} \pm 5,33 \times 10^{1} \mathrm{dm}^{3} \mathrm{~mol}^{-1}\right)$.

Mindezek tükrében megállapítható, hogy a szenzorgramok pszeudo-elsőrendü kinetikai modellel történő illesztését lehetővé tévő táblázatkezelő alapú eljárást kidolgozása után sikeresen alkalmaztam a módszert a szenzorfelületen kialakuló kötési komplex keletkezését és bomlását jellemző sebességi állandók meghatározására. Továbbá igazoltam, hogy az SPR technika általi szilárd/folyadék határfelületen kivitelezett modellezés sikeresen hozzájárulhat a fehérje-alapú gyógyszerhordozó rendszer tervezéséhez a BSA és IBU közötti kötés jellegü kölcsönhatás kvantitatív jellemzése által.

\subsection{Az AMPA receptort modellező (GluR1270-300) polipeptid és a KYNA kölcsönhatásának modellezése SPR szenzorfelületen}

\subsubsection{Az AMPA receptor alegységet modellezö GluR1270-300 polipeptid szintézise és karakterizálása}

A KYNA és receptora közötti kölcsönhatás modellezését és jellemzését célzó SPR vizsgálatok során az ismert szerkezetủ AMPA receptor [59,60] 1-es alegység modelljeként a korábban előállított és alkalmazott két polipeptid (GluR1201-230 és GluR1 $231-259$ [58]) mellett egy újabb, GluR1270-300 jelölésủ polipeptid került előállításra. A receptor modellként felhasznált polipeptid kereskedelmi forgalomban nem érhető el, így szilárdfázisú szintézise útján, a megfelelően megválasztott és Fmoc-csoporttal védett aminosavak összekapcsolásával került előállításra. A szilárdfázisú szintéziseket és a fagyasztva szárított termékek szemipreparatív fordított fázisú HPLC eljárás általi tisztítását Dr. Szolomájer János (SZTE ÁOK Orvosi Vegytani Intézet) végezte. A peptidek moláris tömegének meghatározását célzó, Finnigan TSQ-7000 típusú hármas-kvadrupól készülékkel kivitelezett tömegspektrometriás (MS) vizsgátokat Dr. Kele Zoltán (SZTE ÁOK Orvosi Vegytani Intézet) végezte. A GluR1270-300 jelölésü, 270-es ciszteintől a 300-as metioninig terjedő, CKNSDARDHTRVDWKRPKYTSALTYDGVKVM aminosav sorrendü polipeptid számított moláris tömege $\mathrm{M}=3640,12 \mathrm{~g} \mathrm{~mol}^{-1}$, míg az MS technikával meghatározott érték $\mathrm{M}=3639,80 \mathrm{~g} \mathrm{~mol}^{-1}$.

A fragmensek szintézise és karakterizálása mellett az arany felületre kötött szekvenciák és a KYNA között kialakuló kötés analízisét molekuladinamikai (MD) szimulációk révén Dr. Bogár Ferenc (SZTE ÁOK Orvosi Vegytani Intézet) végezte. A 
többlépéses szimuláció sorozatban elsőként a polipeptid 3D-modellje készült el az AMPA receptor N-terminális doménjének röntgenszerkezetén [82] alapuló modell alkalmazásával, amely a Schrödinger ${ }^{35}$ szoftvercsomag Prime moduljával generálódott. A második lépésben a polipeptid arany és víz alkotta határfelülethez rögzített modellje készült el a Gromacs molekuláris dinamikai szoftver [83] és a GolP felületi modell [84] segítségével. Utóbbi eljárás a felületi polarizációs hatást figyelembe vevő molekula mechanikai leírást ad az $\mathrm{Au}$ (111) felület és a vízben szolvatált polipeptid kölcsönhatásáról. A szimulációk során alkalmazott modellek szerkezetét és a GluR1 $1_{270-300}$ jelölésü polipeptid feltételezett szenzorfelületi orientációját a 23. ábra szemlélteti.
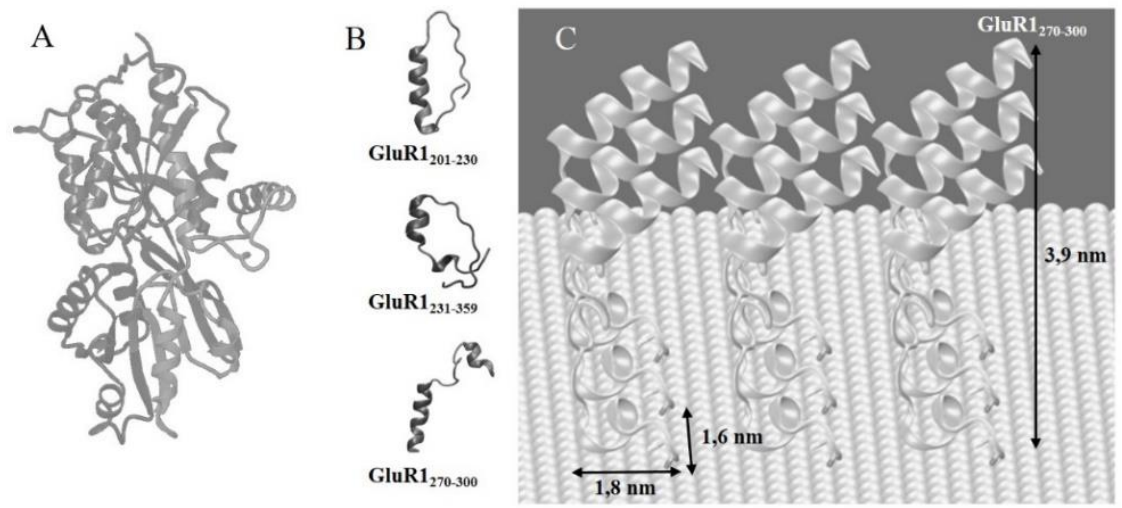

23. ábra: Az AMPA receptor $N$-terminális doménjének homológia modellje (A), a receptor alegységet mintázó polipetidek modelljei (B) és a GluR1270-300 feltételezett szenzorfelületi orientációja (C)

A 23. ábra C részén feltüntetett elrendeződésben egyetlen GluR $1_{270-300}$ polipeptid modellje $\sim 2,9 \mathrm{~nm}^{2}$ nagyságú felületet foglal el a szenzor felületén, míg a modellek alkotta adszorpciós réteg 3,9 nm vastagságú. A szimulációk során megállapított kötési pozíciók túlnyomó többségében a KYNA sóhidat képezve a polipeptid pozitív töltésű arginin (Arg) vagy lizin (Lys) oldallánchoz kötődött. A kötési szabad szabadentalpia $(\Delta \mathrm{G})$ becsült értéke a GluR1 $201-$ 230, GluR1 231-259 és GluR1 270-300 polipetidek esetében rendre -29, -25 és -31 kJ mol ${ }^{-1}$ értéknek adódott. $\mathrm{PhD}$ munkám során a fentiekben vázolt $\mathrm{MD}$ szimulációk eredményét megerősítendő, SPR-alapú vizsgálatok által jellemeztem a GluR $1_{270-300}$ polipeptid és KYNA kölcsönhatását, amelyek kivitelezését, kiértékelését és eredményeit a következő fejezetben foglalom össze.

\footnotetext{
${ }^{35}$ Prime, v3.8, Schrödinger, LLC New York, NY, 2014.
} 


\subsubsection{Az SPR szenzor felületének funkcionalizálása GluR1 270-300 polipeptiddel}

Az SPR szenzor felületének funkcionalizálása során a 2.3.2. fejezetben leírtakkal azonos módon, fiziológiás körülményeket közelítő, neutrális $(\mathrm{pH}=7,4$ (PBS)) kémhatású, c $=30 \mu \mathrm{M}$ koncentrációjú GluR1270-300 polipeptid oldatot alkalmazva alakítottam ki a receptor szilárd/folyadék határfelületi modelljét. A feleslegben jelenlévő polipeptid szenzorfelületről való pufferes lemosását követő állandósult szenzorjel alapján a receptor modell fragmens irreverzibilis módon kötődött a szenzor felületéhez. Az irreverzibilisen kötött polipeptid réteg a szenzor arany felülete és a polipeptid 270- helyzetü ciszteinjének kéntartalmú funkciós csoportja között kialakuló kovalensen kötés révén alakul ki [56]. A szenzorfelület GluR1270-300 polipeptiddel történő funkcionalizálása során rögzített szenzorgram a 24. ábra A részén látható, amelynek belső grafikonján a reflektancia görbék kezdeti (fekete folytonos vonal) és funkconalizálást követő (szürke folytonos vonal) állapota került feltüntetésre. A tiszta arany- és a funkcionalizált szenzorfelület esetében regisztrált szenzorjel különbsége: $\Delta \lambda=8,06 \mathrm{~nm}$, ami az 5.1.1. fejezetben ismertetett kalibráció alapján 213,6 $\pm 2,1 \mathrm{ng} \mathrm{\textrm {cm } ^ { - 2 }}$ adszorbeált tömegnek felel meg.
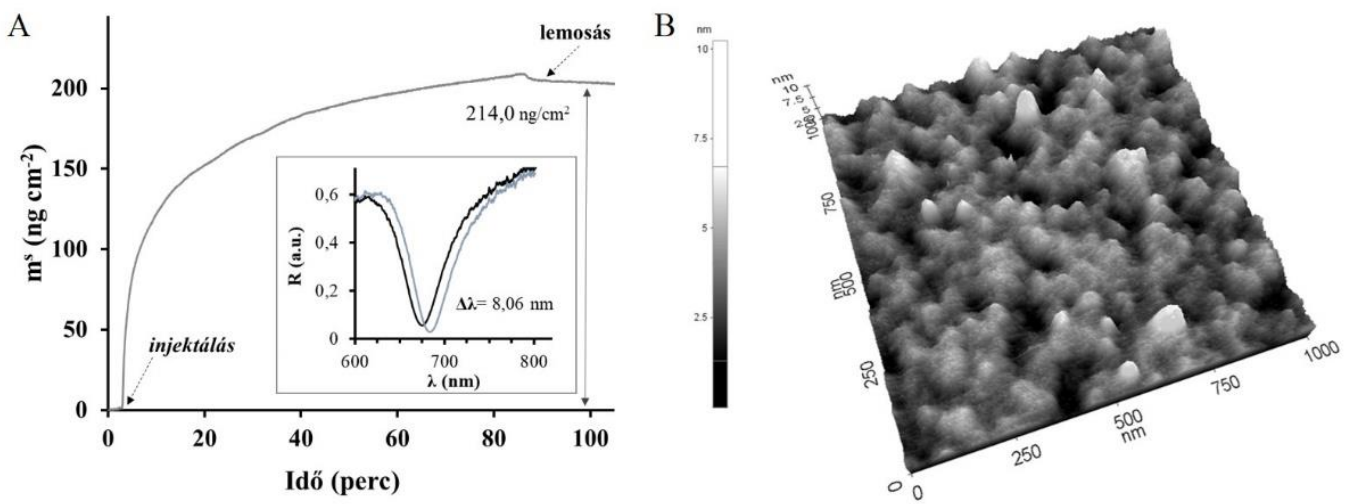

24. ábra: Az SPR szenzorfelület GluR $1_{270-300}$ polipeptiddel történő funkcionalizálása $\left(\right.$ PEPTID $\left.=30 \mu \mathrm{M} ; \mathrm{pH}=7,4 ; \mathrm{PBS} ; q_{v}=50 \mu \mathrm{L}_{\text {perc }}{ }^{-1}\right)$ során rögzített szenzorgram (A) és a funkcionalizált szenzorfelületről készült reprezentatív AFM felvétel (B)

A receptor modellek által kialakított biomimetikus szenzorfelületek felépülését jellemző szenzogramok alapján meghatározott adszorpciós- és geometriai paraméterek értékeit a MarvinSketch nevü szoftverrel számított minimális és maximális vetületek értékekeivel együtt a 3. táblázat foglalja össze. A 3. táblázat adatait szemlélve megállapítható, hogy kísérleti felületigények értéke a számított minimális vetület adatok értékét közelíti, így valószínűsíthető a $\mathbf{2 3}$. ábra $\mathbf{C}$ részén feltüntetett orientáció helyessége. 
A vertikális határfelületi elrendeződés kísérleti úton történő igazolása érdekében az SPR vizsgálatok végeztével a berendezésből eltávolított, GluR1270-300 polipeptiddel funkcionalizált szenzor chipet atomi erő mikroszkópos (AFM) méréseknek vetettük alá. Az AFM vizsgálatokat és eredményeik kiértékelését Dr. Varga Viktória (SZTE TTIK FKAT) végezte.

3. táblázat: Az AMPA receptor alegységet modellező polipeptidek SPR vizsgálat által meghatározott adszorpciós paraméterei és számított geometriai jellemzői

\begin{tabular}{cccccc}
\hline & SPR eredmények & & \multicolumn{2}{c}{ MarvinSketch } \\
\hline Polipeptidek & $\begin{array}{c}\mathrm{m}^{\mathrm{s}} \\
\left(\mathrm{ng} \mathrm{cm}^{-2}\right)\end{array}$ & $\begin{array}{c}\Gamma_{\mathrm{m}} \\
\left(\mathrm{mol} \mathrm{m}^{-2}\right)\end{array}$ & $\begin{array}{c}\mathrm{a}_{\mathrm{m}} \\
\left(\mathrm{nm}^{2}\right)\end{array}$ & $\begin{array}{c}\mathrm{a} \mathrm{m}, \text { min. } \\
\text { számított } \\
\left(\mathrm{nm}^{2}\right)\end{array}$ & $\begin{array}{c}\mathrm{a}_{\mathrm{m}, \text { max. }} \\
\text { számított } \\
\left(\mathrm{nm}^{2}\right)\end{array}$ \\
\hline GluR1 $_{201-230^{*}}$ & $198,8 \pm 2,3$ & $0,58 \pm 0,01$ & $2,85 \pm 0,05$ & 3,76 & 4,99 \\
GluR1 $_{231-259^{*}}$ & $204,5 \pm 2,4$ & $0,60 \pm 0,01$ & $2,77 \pm 0,05$ & 3,25 & 7,04 \\
GluR1 $_{270-300}$ & $213,6 \pm 2,1$ & $0,59 \pm 0,01$ & $2,84 \pm 0,04$ & 3,28 & 5,92 \\
\hline
\end{tabular}

* A GluR $1_{201-230}$ és GluR $1_{231-259}$ polipeptidekre vonatkozó adatok korábban már publikált [58] eredmények csupán az összehasonlíthatóság érdekében szerepelnek a táblázatban.

A 24. ábra B részén látható AFM felvételen a mesterséges színskála igyekszik szemléletesen ábrázolni a nanométeres skálán strukturált határfelületi réteg vertikális kiterjedésének változását és a felület morfológiáját. Az AFM mérések vonalprofil analízise igazolta, hogy a kemiszorbeált polipeptid réteg maximálisan $3 \mathrm{~nm}$-es fluktuációkat mutat, ami egyrészt jól közelíti a MD szimulációs rétegmodell 3,9 nm-es vastagságát, másrészt megerősíti a vertikális orientációval jellemezhető adszorpciós modell helyességét.

\subsubsection{A KYNA szilárd/folyadék határfelületi adszorpciójának vizsgálata GluR $1_{270-300}$ polipeptiddel funkcionalizált szenzorfelületen}

A GluR1270-300 polipeptiddel módosított szenzorfelület kialakítását követően a különböző koncentrációjú és PBS közegü KYNA oldatok szenzorfelület felett történő átáramoltatása révén vizsgáltam a potenciális hatóanyag receptor modellen történő megkötődését. A héttagú oldatsorozatban a KYNA koncentrációja rendre 0,5; 1,0; 1,5; 2,0; 3,0; 4,0 és 5,0 mM nagyságú volt a méréseket pedig 10 és $40 \mathrm{C}^{\circ}$ közötti hőmérséklet tartományban, négy különböző hőmérsékleten végeztem el. A koncentráció- és hőmérséklet függő mérések során rögzített szenzorgramokat a 25. ábra foglalja össze. A szenzorgramok a mérési körülményektől függetlenül minden esetben a KYNA reverzibilis kötődést jelezték. Az asszociációs fázisok telítési szakaszai pedig a hőmérséklet növekedésével egyre kisebb mértékü szenzorfelületi feldúsulást jeleztek. A telítési szakaszokhoz rendelhető hullámhossz 
eltolódás értékek ismeretében az 5.1.1. fejezetben ismertetett kalibráció útján minden egyensúlyi koncentrációhoz hozzárendelhettem a KYNA funkcionalizált szenzorfelületen adszorbeált anyagmennyiségét $(\Gamma)$, ezáltal elkészíthettem a KYNA adszorpciós izotermái.
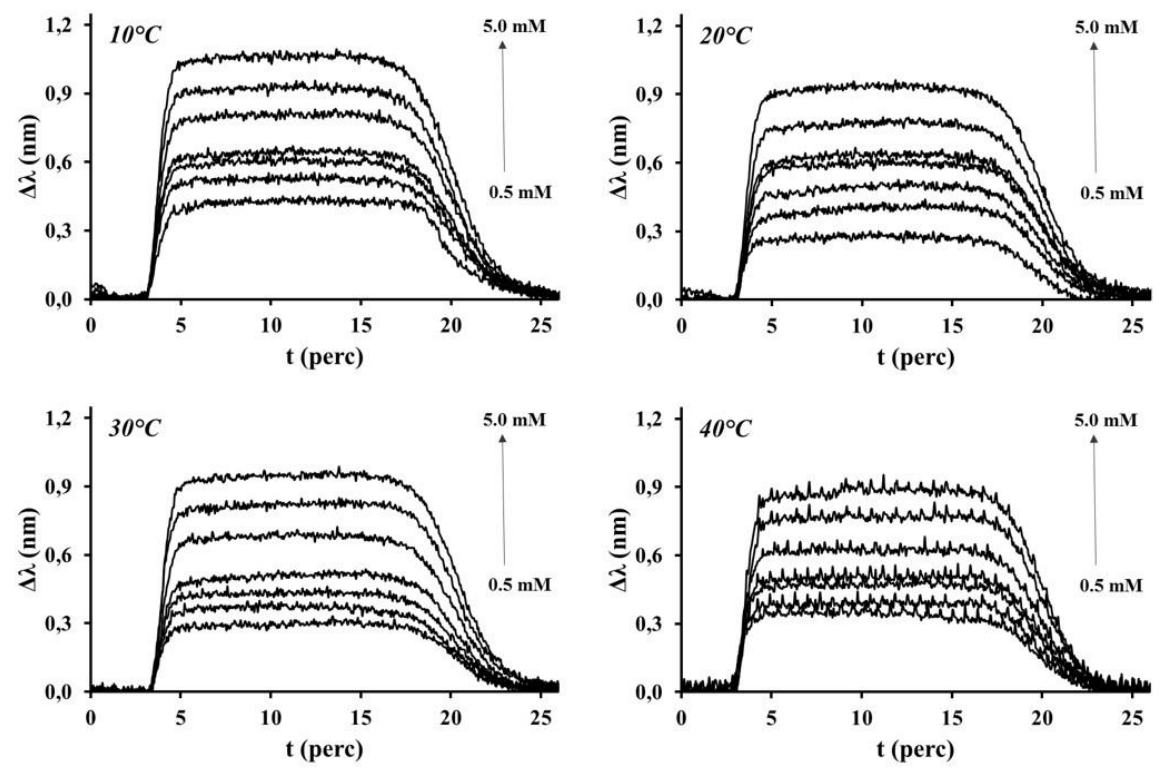

25. ábra: A KYNA oldatfázisból GluR1 $270-300$ polipeptiddel funkcionalizált SPR szenzorfelületen végbemenő feldúsulásának koncentráció- és hőmérséklet függő vizsgálata során rögzített szenzorgramok $\left(\mathrm{pH}=7,4 ; \mathrm{PBS} ; q_{v}=50 \mu \mathrm{L}\right.$ perc $\left.^{-1}\right)$

A szenzorgramok által szolgáltatott adatok adszorpció alapú kiértékelése során elsőként a kísérleti úton meghatározott izotermák adszorpciós modellel történő illesztése útján kívántam meghatározni azon függvényeket, amelyek lehetővé teszik a tetszőlegesen választott $\theta^{36}$ érték mellett az egyensúlyi koncentráció és hőmérséklet alkotta adatpárok meghatározását. A kísérleti adatok illesztését Langmuir, Freundlich és BET izoterma egyenletek alapján [85], nemlineáris paraméterbecslés útján végeztem el, majd ezek közül a legjobb illesztést eredményező, 5.15. formában megadható BET egyenlet segítségével alkotott függvényt alkalmaztam a további számításokhoz.

$$
\Gamma=\frac{C_{K Y N A} K_{B} \Gamma_{m}}{\left(C_{K Y N A}-C_{S}\right)\left\{1+\left(K_{B}-1\right)\left(C_{K Y N A} / C_{S}\right)\right\}}
$$

Az 5.15. egyenlet paraméterkészletének $\left(\Gamma_{m}, K_{B}\right.$ és $\left.c_{s}\right)$ nemlineáris paraméterbecslés útján történő meghatározását követően szabadon választott felbontású $\theta$ skálához rendelhető egyensúlyi KYNA koncentráció érték minden vizsgált hőmérséklet esetén. A 26. ábra A

\footnotetext{
${ }^{36}$ A vizsgált rendszer esetében a felületi borítottság $\theta=\Gamma_{(K Y N A)} / \Gamma_{m(K Y N A)}$ összefüggéssel definiálható, ahol $\Gamma_{m(K Y N A)}=0,086 \mathrm{nmol} \mathrm{cm}^{-2}[86]$.
} 
részén, a KYNA GluR1270-300 polipeptiddel funkcionalizált SPR szenzorfelületen végbemenő feldúsulását jellemző adszorpciós izotermák esetében a vízszintes fekete pontozott vonal szemlélteti a $\theta=1,0$ borítottság értéket, amelyhez minden hőmérsékleten egy adott adszorbeált anyagmennyiség $\left(\Gamma_{m}\right)$ érték és négy eltérő KYNA koncentráció rendelhető. A négy hőmérséklet és koncentráció alkotta adatpár ismeretében számítható az adott borítottsághoz rendelhető entalpiaváltozás $\left(\Delta H^{0} a d\right)$ amelyet az izoszter adszorpciós hőt definiáló 5.16. egyenlet alapján számíthatunk [85].

$$
\Delta H_{a d}^{0}=-R\left\{\frac{d\left(\ln C_{K Y N A}\right)}{d(1 / T)}\right\}_{\theta}
$$

Az 5.16. egyenletben szereplő differenciálhányados értéke a 26. ábra $B$ részén bemutatott módon lineáris regresszió útján számítható, így a teljes borítottság skálán meghatározható $\Delta H^{0}{ }_{a d}$ értéke. A $\theta$ értékek mindegyike megfeleltethető egy felületegységre vonatkoztatott GluR1 270-300 polipeptid és KYNA közötti anyagmennyiség aránynak $\left(\mathrm{n}_{\text {peptid }}^{\mathrm{s}}: \mathrm{n}^{\mathrm{s}} \mathrm{KYNA}\right)$, amely a szenzorfelületen kialakuló $\mathrm{AB}$ kötési komplex sztöchiomeriájaként is értelmezhető.
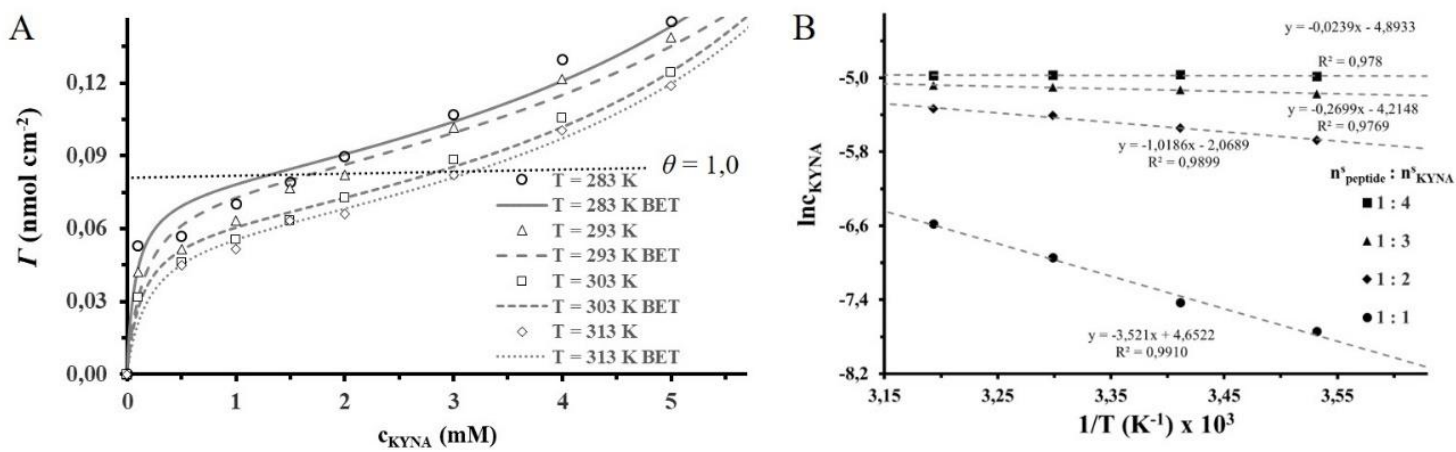

26. ábra: A KYNA GluR1 270-300 polipeptiddel funkcionalizált SPR szenzorfelületen végbemenő feldúsulását jellemző adszorpciós izotermák (A) és az izoszer adszorpciós hő $\left(\Delta H^{0}{ }_{a d}\right)$ meghatározását lehetővé tévő lineáris regresszió reprezentatív bemutatása négy eltérő felületi anyagmannyiség arány mellett

Mindezek ismeretében a felületi borítottság és a kölcsönható partnerek sztöchiometriai arányának függvényében egyaránt vizsgálhatóvá vált az adszorpciós- illetve a receptorligandum közötti kötési folyamatot kísérő entalpia változása, amelyet a 27. ábra görbéi szemléltetnek. A GluR1270-300 polipeptiddel funkcionalizált SPR szenzorfelület esetében a $\Delta H^{0}{ }_{a d}=\mathrm{f}(\theta)$ függvény minimuma $\theta=1,1$ borítottságnál $30 \mathrm{~kJ} \mathrm{~mol}^{-1}$ értéket vesz fel, amely a felületegységre vonatkoztatott anyagmennyiség arány függvényen $n^{\mathrm{s}}{ }_{\text {peptid }}: \mathrm{n}^{\mathrm{s}}{ }_{\mathrm{KYNA}}=0,88$ aránynál jelenik meg. A 27. ábra grafikonjain a GluR1270-300 és a KYNA közötti 
kölcsönhatást jellemzö függvények mellett, a korábban vizsgált GluR1201-230 és GluR1231-259 fragmensek [86] esetében meghatározott $\Delta H^{0}{ }_{a d}=\mathrm{f}(\theta)$ és $\Delta H^{0}{ }_{a d}=\mathrm{f}\left(\mathrm{n}^{\mathrm{s}}{ }_{\text {peptid }}: \mathrm{n}^{\mathrm{s}}{ }_{\mathrm{KYNA}}\right)$ függvények is feltüntetésre kerültek a könnyebb összevethetőség érdekében. A vizsgált alegység modellek és a KYNA kölcsönhatását jellemző entalpia függvények minimumhelyeihez rendelhető entalpia-, borítottság- és a felületegységre vonatkoztatott anyagmennyiség arány értékeit a 4. táblázat foglalja össze.
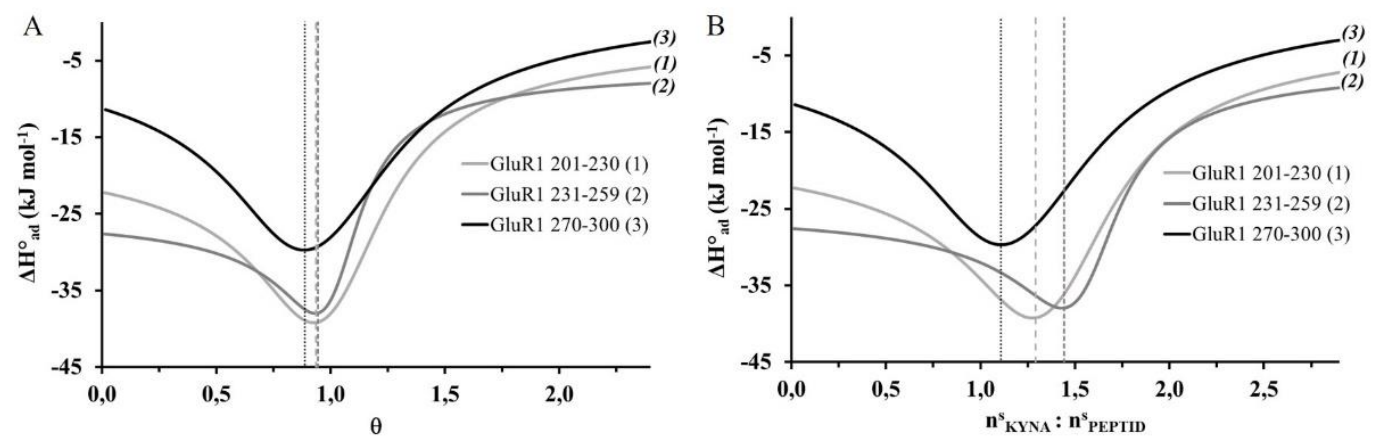

27. ábra: A KYNA GluR1 270-300 polipeptiddel funkcionalizált SPR szenzorfelületi adszorpcióját kísérő $\Delta H^{0}{ }_{a d}$ változása a felületi borítottság (A) és a felületegységre vonatkoztatott GluR $1_{270-300}$ és KYNA közötti anyagmennyiség arány (B) függvényében

A 4. táblázat által összefoglalt paraméterek értékeit tekintve megállapítható, hogy az AMPA receptor alegység modellek és a KYNA kölcsönhatását jellemző entalpia függvények a vizsgált alegység modellek mindegyike esetében azonos, átlagosan $\theta=0,91$ borítottság értéknél jelenik meg az extrémum, ami egyben azt is jelzi, hogy energetikailag a 1:1 sztöchiometriával bíró kötési komplex kialakulása a kedvezményezett.

4. táblázat: Az AMPA receptor alegység modellek és KYNA kölcsönhatást jellemző entalpia függvények minimumhelyeihez rendelhető entalpia-, borítottság- és felületegységre vonatkoztatott anyagmennyiség arány értékei

\begin{tabular}{cccc}
\hline Polipeptidek & $\Delta H^{0}{ }_{a d}\left(\mathrm{~kJ} \mathrm{~mol}^{-1}\right)$ & $\theta$ & $\mathrm{n}_{\text {peptid }}^{\mathrm{s}}: \mathrm{n}^{\mathrm{s}}$ KYNA \\
\hline GluR $1_{201-230^{*}}$ & $-39,2$ & 0,92 & 1,28 \\
GluR $_{231-259^{*}}$ & $-38,0$ & 0,93 & 1,43 \\
GluR $_{270-300}$ & $-29,7$ & 0,88 & 1,11 \\
\hline
\end{tabular}

* A GluR1 $1_{201-230}$ és GluR1 $231-259$ polipeptidekre vonatkozó adatok korábban már publikált [87] eredmények csupán az összehasonlíthatóság érdekében szerepelnek a táblázatban

Az AMPA receptor alegységet modellező GluR1270-300 polipeptid és KYNA kölcsönhatásának szilárd/folyadék határfelületen, SPR technika által kivitelezett modellezése során a szenzorgramok kvázi egyensúlyt (állandósult állapotot) feltételező 
kiértékelése révén megszerkesztettem a KYNA szenzorfelületen végbemenő feldúsulását jellemző adszorpciós izotermákat. A kísérleti izotermák BET adszorpciós modellel történő illesztését követően meghatároztam az adszorpciós- és ezzel együtt a receptor-ligandum közötti kötési folyamatot kísérő izoszter entalpiaváltozás függvényt. Az állapotfüggvény minimum helye alapján megállapítottam, hogy a GluR1270-300 polipeptid és KYNA kötési komplexének spontán végbemenő exoterm kialakulása során az 1:1 sztöchiometriával jellemezhető határfelületi asszociátum kialakulása kedvezményezett.

\subsubsection{A KYNA szenzorfelületen immobilizált GluR $1_{270-300}$ polipeptiden végbemenö} reverzibilis kötödésének kinetikai vizsgálata

Az AMPA receptor alegységet modellező GluR1270-300 polipeptid és KYNA közötti kölcsönhatás koncentráció- és hőmérsékletfüggő SPR szenzorikai vizsgálata során rögzített szenzorgramok az 5.2.2. fejezetben bemutatott és a szenzorfelületen kialakuló kötési komplex koncentrációjának időbeni változását modellező kiértékelési módszer útján is feldolgozhatók. A 25. ábra által összefoglalt koncentráció- és hőmérsékletfüggő szenzorgramok pszeudo-elsőrendü kinetikai közelítés (5.13. egyenlet) alkalmazása alapján történő modellezése során kapott eredményeket a 28. ábra szemlélteti.
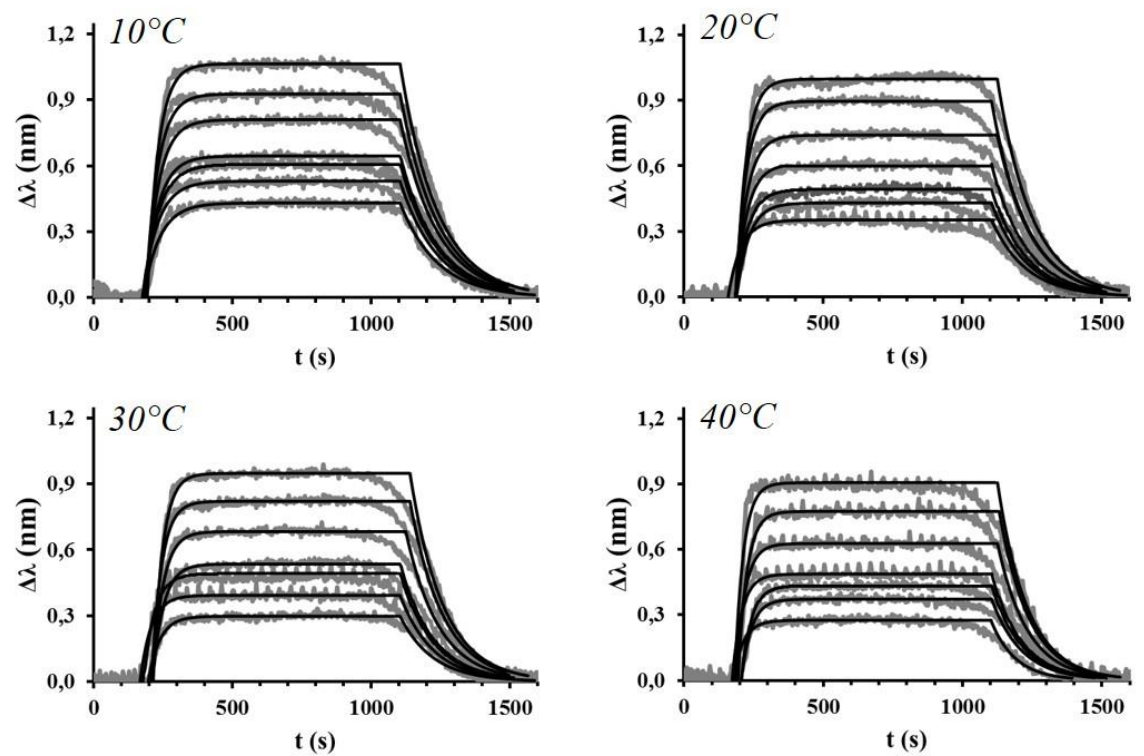

28. ábra: A KYNA oldatfázisból GluR1270-300 polipeptiddel funkcionalizált SPR szenzorfelületen végbemenő feldúsulásának vizsgálata során rögzített szenzorgramok és pszeudo-elsőrendű sebességi egyenlettel (5.14.) illesztett modellgörbéik 
Az 5.13. egyenlet mellett a szenzorgramok lemosási szakaszaiban rögzített adatok modellezésére felhasználható a szenzorfelületen kialakuló $A B$ kötési komplex bomlását leíró elsőrendủ sebességi egyenlet, amelyet az 5.17. kifejezés határoz meg.

$$
[A B]=[B]_{0} e^{-k_{o f f} t}
$$

Az 5.17. egyenletben szereplő $k_{\text {off }}$ bomlási sebességi állandó indexelése a pszeudo-elsőrendü sebességi egyenlet (5.14.) alapján definiált $k_{o b s}$ koncentráció-függéséből számított $k_{d}$ disszociációs sebességi állandótól hívatott megkülönböztetni a tisztán nemlineáris paraméterbecslés útján meghatározható valós sebességi állandót. Az 5.11. és 5.12 . összefüggések alapján a bomlási sebességi állandót tartalmazó 5.17. egyenlet az alábbi 5.18. formában adható meg.

$$
\Delta \lambda=\Delta \lambda_{\max } e^{-k_{o f f} t}
$$

Az 5.18. integrált sebességi egyenletet 5.2.2. fejezetben bemutatott módszer alapján alkalmazva a szenzorgramok lemosási szakaszainak illesztésére a 28. ábra által szemléltetett modellgörbékhez jutunk, amelyek a szenzorfelületen kialakuló AB kötési komplex keletkezését és bomlását egyaránt jól leírják.

A nemlineáris paraméterbecslést követően minden alkalmazott KYNA koncentráció és mérési hőmérséklet esetében rendelkezésemre álltak a $k_{o b s}$ értékek, ezeket a KYNA koncentrációjának függvényében ábrázolva a 29. ábra által bemutatott adatsorokat kaptam, amelynek az 5.6. egyenlet alapján végzett lineáris regressziója által a valós sebességi állandók értékét határozhattam meg.

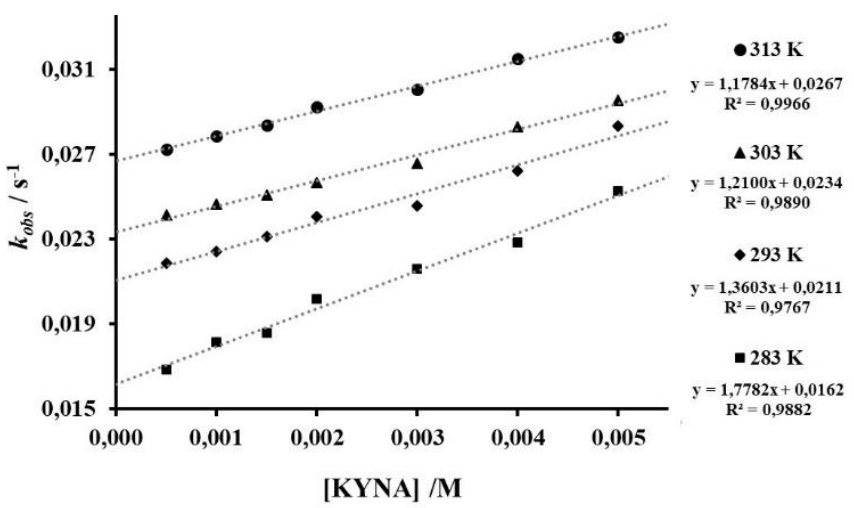

29. ábra: A KYNA és GluR1270-300 polipeptid alkotta kötési komplex kialakulását és disszociációját jellemző valós sebességi állandók meghatározása a $k_{o b s}$ koncetrációfüggésének (5.6. egyenlet) lineáris regressziója által 
A 29. ábra által szemléltetett lineáris regressziós módszer lehetőséget ad az illesztett egyenes meredeksége alapján meghatározott $k_{a}$ és a tengelymetszet alapján származtatott $k_{d}$ értékek sztenderd deviációjának számítására is. A lineáris regresszió során azonban csak rendkívül jó illeszkedés esetén várható, hogy a tengelymetszet sztenderd deviációja elfogadható nagyságú legyen. Az általam alkamzott szenzorikai vizsgálatok esetében jellemzően tíznél kevesebb adatpár alapján kell elvégezni illesztést így az illesztett adatok bizonytalansága könnyedén erdményezhet a meghatározott $k_{d}$ értékénével összemérhető vagy akár azt meghaladó nagyságú szórásértéket [88-90]. Ezért előnyös, ha az összes vizsgált analit koncentrációhoz rendelhető szenzorram együttes illesztését végezzük el a J. O'Shannessy és munkatársai által javasolt [91] és az 5.11. valamint 5.12. összefüggések révén az 5.19. formában megadható integrált sebességi egyenletnek megfelelően.

$$
\Delta \lambda=\Delta \lambda_{\max } \frac{k_{a}[A]}{k_{a}[A]+k_{d}}\left\{1-e^{-\left(k_{a}[A]+k_{d}\right) t}\right\}
$$

Az 5.19. egyenlet alapján végzett menlineáris parméterbecslés révén minden vizsgált hőmérsékleten közvetlenül adódik lehetöség a $k_{a}, k_{d}$ és $\Delta \lambda_{\max }$ paraméterkészlet meghatározására további regresziós eljárás alkalmazása nélkül. A szenzorgramok együttes kiértékelését lehetővé tévő 5.19. sebességi egyenlet alapján készített modellgörbék azonban kevésbé helyesen írják le a kísérleti adatokat, ahogyan azt a 30. ábra szenzorgramjainak és modellgörbéinek viszonya szemlélteti.
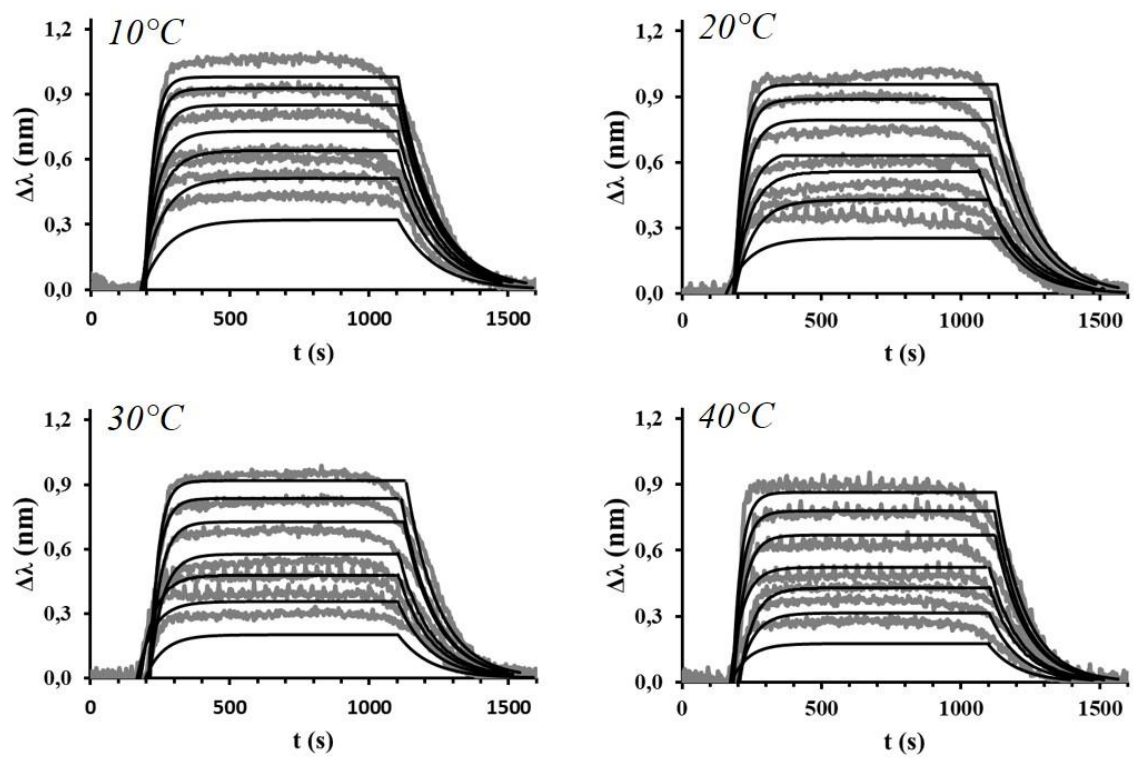

30. ábra: A KYNA GluR1270-300 polipeptiddel funkcionalizált SPR szenzorfelületen végbemenő feldúsulásának vizsgálata során rögzített szenzorgramok együttes értékelését lehető tevő sebességi egyenlet (5.19.) alapján illesztett modellgörbéi 
A modellillesztés jóságának minősítésére általánosan használt $R^{2}$ értékek helyett a GluR $1_{270-}$ 300 polipeptid és KYNA alkotta kötés komplex kialakulását és disszociációját modellező kinetikai görbék illesztése során is a khi négyzet próba $\left(\chi^{2}\right)$ által szolgáltatott adatokkal jellemeztem az illesztések jóságát. A modellillesztések paramétereként meghatározott $k_{a}$ és $k_{d}$ értékeket valamit ezek sztenderd deviációját továbbá a $\chi^{2}$ értékeit az 5. táblázat adott mérési hőmérsékletre vonatkozó sorai foglalják össze a diszkrét- és az együttes illesztés útján származtatott esetekben. Az 5. táblázat vonatkozó oszlopaiban szereplő $\chi^{2}$ értékek összevetése számszerüsített adatokkal erősíti meg azt a korábbi megfigyelést, hogy az együttes kiértékelését lehetővé tévő 5.19. sebességi egyenlet alapján készített modellgörbék esetén sokkal rosszabb az illesztések minősége, mint a diszkrét illesztések esetében. Mindemellett a több hőmérsékleten megismételt méréssorozat előnye abban rejlik, hogy az 5. táblázat által összefoglalt sebességi állandók hányadosaként rendelkezésre álló egyensúlyi állandó $\left(K_{A}=k_{a} / k_{d}\right)$ szolgáltatja a szabadentalpia változás értékét és hőmérsékletfüggése révén lehetőséget biztosít a kötési komplex kialakulását kísérő entalpiaés entrópia-változás meghatározására.

5. táblázat: A GluR1270-300 polipeptid és KYNA alkotta kötés komplex kialakulását és disszociációját jellemző szenzorgramok diszkrét- és együttes illesztése útján meghatározott sebességi állandók

\begin{tabular}{cccc|ccc}
\hline \multicolumn{4}{c|}{ Diszkrét illesztés (5.14.) } & \multicolumn{3}{|c}{ Együttes illesztés (5.19.) } \\
\hline $\mathrm{T}$ & $\begin{array}{c}k_{a} \\
(\mathrm{~K})\end{array}$ & $\begin{array}{c}k_{d} \\
\left(\mathrm{M}^{-1} \mathrm{~s}^{-1}\right)\end{array}$ & $\left.\mathrm{s}^{-1}\right)$ & & $k_{a}$ & $\mathrm{k}_{\mathrm{d}}$ \\
$\left(\mathrm{M}^{-1} \mathrm{~s}^{-1}\right)$ & $\left.\mathrm{s}^{-1}\right)$ & $\chi^{2}$ \\
\hline 283,15 & $1,778 \pm 0,230$ & $0,0162 \pm 0,0007$ & 0,932 & $5,591 \pm 0,625$ & $0,0082 \pm 0,0009$ & 2,479 \\
293,15 & $1,360 \pm 0,248$ & $0,0211 \pm 0,0007$ & 0,322 & $4,587 \pm 0,598$ & $0,0102 \pm 0,0013$ & 2,846 \\
303,15 & $1,210 \pm 0,151$ & $0,0234 \pm 0,0004$ & 0,241 & $4,116 \pm 0,518$ & $0,0134 \pm 0,0017$ & 1,745 \\
313,15 & $1,178 \pm 0,082$ & $0,0267 \pm 0,0002$ & 0,594 & $3,845 \pm 0,575$ & $0,0148 \pm 0,0022$ & 2,770 \\
\hline
\end{tabular}

Megállapítható tehát, hogy a KYNA GluR $1_{270-300}$ polipeptiddel funkcionalizált SPR szenzorfelületen végbemenő reverzibilis megkötődsének vizsgálata során a szenzorgramok pszeudo-elsőrendű kinetikai modellel történő illesztését lehetővé tévő táblázatkezelő alapú eljárás révén sikeresen határoztam meg a szenzorfelületen kialakuló kötési komplex keletkezését és bomlását jellemző valós sebességi állandók értékét. 


\subsubsection{A KYNA szenzorfelületen immobilizált GluR $1_{270-300}$ polipeptiden végbemenö} reverzibilis kötödésének van't Hoff analizise

A hőmérséklet szabályozott SPR platform alkalmazása révén a KYNA GluR $1_{270-300}$ polipeptiddel funkcionalizált SPR szenzorfelületen végbemenő reverzibilis megkötődését jellemző szenzorgramok négy hőmérsékleten kerültek rögzítésre. A kinetikai modell illesztése révén a látszólagos majd a valós sebességi állandók számítását követően a kölcsönhatás egyensúlyi állandója is meghatározhatóvá vált minden egyes hőmérsékleten. A $K_{A}$ értékének ismeretében a reverzibilis kötési folyamathoz rendelhető szabadentalpia $(\Delta G)$ változás az 5.18. összefüggés szerint kalkulálható.

$$
\Delta \mathrm{G}=-\mathrm{RT} \ln K_{A}
$$

A $\Delta G$ és a $K_{A}$ természetes alapú logaritmusa közötti összefüggésben $R$ az egyetemes gázállandót (8,314 $\left.\mathrm{J} \mathrm{mol}^{-1} \mathrm{~K}^{-1}\right)$, míg $T$ az abszolút hőmérsékletet jelöli. A $K_{A}$ (vagy a $\Delta \mathrm{G}$ ) hőmérsékletfüggését leíró és 5.19. formájú van’t Hoff összefüggés segítségével a kötési folyamat sztenderd entalpia- $\left(\Delta H^{\circ}\right)$ és entrópia $\left(\Delta S^{\circ}\right)$ változása határozható meg.

$$
\ln K_{A}=\frac{-\Delta H^{0}}{R T}+\frac{\Delta S^{0}}{R}
$$

Az 5.19. egyenlet értelmében a $K_{A}$ természetes alapú logaritmusát ábrázolva a hőmérséklet reciprokának függvényében és a kapott adatsorra egyenest illesztve annak meredeksége egyenlő lesz a $\Delta H^{o}$ és az $R$ hányadosának ellentettjével $\left(-\Delta H^{o} / R\right)$, míg tengelymetszete a $\Delta S^{o}$ és az $R$ hányadosaként adódik $\left(\Delta S^{\%} / R\right)$. Ennek megfelelően a KYNA és a GluR $1_{270-300}$ polipeptid SPR szenzorikai vizsgálata során nyert adatok kiértékelésének következő lépésében az $\ln K_{A}$ értékek hőmérséklet függése alapján számítottam az említett állapotfüggvények változásának értékét a van 't Hoff analízis alapján. A 31. ábra A és B része mutatja be a GluR1270-300 polipeptid és KYNA alkotta kötés komplex képződésének vizsgálat során a szenzorgramok diszkrét- és együttes illesztése útján meghatározott $K_{A}$ értékek természetes alapú logaritmusát a reciprok hőmérséklet függvényében. A $K_{A}$ értékét az 5. táblázat által összefoglalt sebességi állandók hányadosaként, sztenderd deviációját pedig ezen állandók szórása ismeretében az elemi hibatranszformációk alkalmazásával számítottam. A 31. ábra $\mathbf{A}$ és $\mathbf{B}$ részén egyaránt szaggatott szürke egyenes jelzi a lineáris van 't Hoff analízis illesztett egyenesét, amelyről szemrevételezés útján is belátható, hogy rendkívül rosszul írja le a kísérleti adatok hőmérsékletfüggését.

A van 't Hoff egyenlet linearitása természetesen csak megfelelően kis hőmérséklet tartományt vizsgálva tételezhető fel, ám az önrendeződő asszociációs kolloidok [92,93] és a 
biológiai rendszerek [94] esetén ez a tartomány lényegesen szűkebb lehet, mit a legtöbb szerves vagy szervetlen vegyület képződése esetében. A lineáris függvénykapcsolat alapvetően abból a megközelítésből ered, hogy megfelelően szűk hőmérséklet tartományban az entalpia és entrópia hőmérsékletfüggése elhanyagolhatóan kicsi.
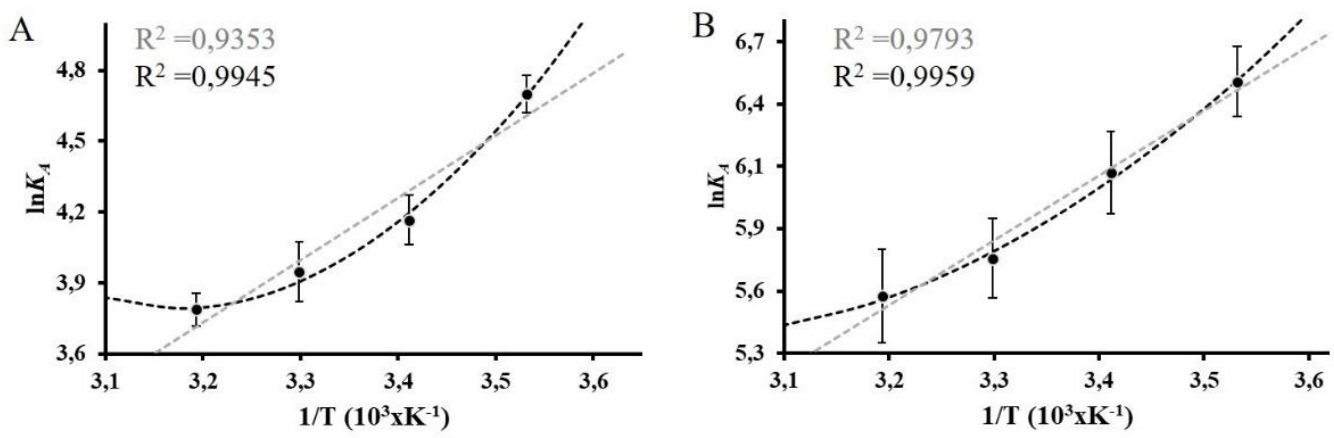

31. ábra: A GluR1 $270-300$ polipeptid és KYNA közötti kölcsönhatást jellemző szenzorgramok diszkrét-(A) és együttes (B) kinetikai modellezése során meghatározott $K_{A}$ értékek van ’t Hoff reprezentációja

A biológiai rendszerek és ezzel együtt az ezeket modellező biomimetikumok esetében azonban szűk hőmérséklet tartományban sem hanyagolható el az entalpia- és entrópiaváltozás hőmérsékletfüggése, amelyeket az állandó nyomásra vonatkozó hőkapacitás által az alábbi 5.20. és 5.21. összefüggések szerint tudunk figyelembe venni [95].

$$
\begin{aligned}
& \Delta \mathrm{H}(T)=\Delta H^{0}\left(T^{0}\right)+\Delta C_{p}\left(T-T^{0}\right) \\
& \Delta \mathrm{S}(T)=\Delta S^{0}\left(T^{0}\right)+\Delta C_{p} \ln \left(T / T^{0}\right)
\end{aligned}
$$

A fenti 5.20. és 5.21. egyenletek világosan szemléltetik, hogy az entalpia vagy az entrópia hőmérsékletfüggése csak akkor hanyagolható el, ha az állandó nyomásra vonatkozó hőkapacitás értéke nulla vagy nullának tekinthető. Ellenkező esetben van 't Hoff ábrázolásban a függvénykapcsolat eltér a lineáristól, ahogyan azt a 31. ábra is jól szemlélteti, így a kötés termodinamikai paramétereit nemlineáris regresszió módszerével, az $\mathrm{f}=\Delta H(T)$ és $\mathrm{f}=\Delta S(T)$ függvényeket figyelemben vevő van 't Hoff egyenlet alábbi 5.22. formájának alkalmazásával határozhatjuk meg [96].

$$
\ln K_{A}=\frac{-\Delta H^{0}\left(T^{0}\right)}{R T}+\frac{\Delta S^{0}\left(T^{0}\right)}{R}+\frac{\Delta C_{p}}{R}\left[\left(\frac{T-T^{0}}{T}\right)-\ln \frac{T}{T^{0}}\right]
$$

A 31. ábra A és B részén a fekete szaggatott vonalak jelölik az 5.22. egyenlet alapján nemlineáris paraméterbecslési eljárással illesztett modellgörbéket, amelyek a linearizált 
formánál sokkal pontosabban tükrözik a $K_{A}$ hőmérsékletfüggését. Mivel minden $K_{A}$ esetében rendelkezésre állt az állandó sztenderd deviációja is, a nem lineáris regressziót az egyes $K_{A}$ értékek szórásának figyelembevételével, súlyozottan ${ }^{37}$ tudtam elvégezni [94]. A GluR1 270300 polipeptid és KYNA alkotta kötés komplex kialakulását és disszociációját jellemző szenzorgramok kinetikai modellezése által származtatott $K_{A}$ értékek nemlineáris van 't Hoff analízise által meghatározott $\Delta H^{o}, \Delta S^{o}$ és $\Delta C_{p}$ értékeit a 6. táblázat foglalja össze. A súlyozott adatkészlet azonban csupán a kísérleti adatok bizonytalanságát képes figyelembe venni, a paraméterbecslésböl származó illesztési paraméterek (esetünkben $\Delta H^{o}, \Delta S^{o}$ és $\Delta C_{p}$ ) szórásának meghatározásához további számításokra van szükség.

6. táblázat: A GluR1270-300 polipeptid és KYNA alkotta kötés komplex kialakulását és disszociációját jellemző szenzorgramok diszkrét- és együttes illesztése útján meghatározott termodinamikai paraméterek

\begin{tabular}{|c|c|c|c|c|c|}
\hline \multicolumn{6}{|c|}{ Diszkrét illesztés (5.14.) } \\
\hline $\begin{array}{c}\mathrm{T} \\
(\mathrm{K})\end{array}$ & $\begin{array}{c}\mathrm{K}_{\mathrm{A}} \\
\left(\mathrm{M}^{-1}\right)\end{array}$ & $\begin{array}{c}\Delta \mathrm{G}^{0} \\
\left(\mathrm{~kJ} \mathrm{~mol}^{-1}\right)\end{array}$ & $\begin{array}{c}\Delta \mathrm{H}^{0} \\
\left(\mathrm{~kJ} \mathrm{~mol}^{-1}\right)\end{array}$ & $\begin{array}{c}\Delta \mathrm{S}^{0} \\
\left(\mathrm{~kJ} \mathrm{~mol}^{-1} \mathrm{~K}^{-1}\right)\end{array}$ & $\begin{array}{c}\Delta \mathrm{C}_{\mathrm{p}} \\
\left(\mathrm{kJ} \mathrm{mol}^{-1} \mathrm{~K}^{-1}\right)\end{array}$ \\
\hline 283,15 & $110 \pm 9$ & $-11,06 \pm 0,19$ & \multirow{4}{*}{$-27,91 \pm 5,27$} & \multirow{4}{*}{$-0,06 \pm 0,02$} & \multirow{4}{*}{$-1,28 \pm 0,54$} \\
\hline 293,15 & $65 \pm 7$ & $-10,16 \pm 0,25$ & & & \\
\hline 303,15 & $52 \pm 7$ & $-9,95 \pm 0,32$ & & & \\
\hline 313,15 & $44 \pm 3$ & $-9,86 \pm 0,18$ & & & \\
\hline \multicolumn{6}{|c|}{ Együttes illesztés (5.19.) } \\
\hline $\begin{array}{c}\mathrm{T} \\
(\mathrm{K}) \\
\end{array}$ & $\begin{array}{c}\mathrm{K}_{\mathrm{A}} \\
\left(\mathrm{M}^{-1}\right) \\
\end{array}$ & $\begin{array}{c}\Delta \mathrm{G}^{0} \\
\left(\mathrm{~kJ} \mathrm{~mol}^{-1}\right)\end{array}$ & $\begin{array}{c}\Delta \mathrm{H}^{0} \\
\left(\mathrm{~kJ} \mathrm{~mol}^{-1}\right)\end{array}$ & $\begin{array}{c}\Delta \mathrm{S}^{0} \\
\left(\mathrm{~kJ} \mathrm{~mol}^{-1} \mathrm{~K}^{-1}\right)\end{array}$ & $\begin{array}{c}\Delta \mathrm{C}_{\mathrm{p}} \\
\left(\mathrm{kJ} \mathrm{mol}^{-1} \mathrm{~K}^{-1}\right)\end{array}$ \\
\hline 283,15 & $679 \pm 107$ & $-15,35 \pm 0,37$ & \multirow{4}{*}{$-27,36 \pm 4,97$} & \multirow{4}{*}{$-0,04 \pm 0,02$} & \multirow{4}{*}{$-0,69 \pm 0,51$} \\
\hline 293,15 & $452 \pm 83$ & $-14,90 \pm 0,45$ & & & \\
\hline 303,15 & $307 \pm 55$ & $-14,43 \pm 0,45$ & & & \\
\hline 313,15 & $259 \pm 50$ & $-14,47 \pm 0,55$ & & & \\
\hline
\end{tabular}

A nemlineáris paraméterbecslés meghatározott termodinamikai adatoknak $\Delta H^{o}, \Delta S^{o}$ és a $\Delta C_{p}$ értéke mellett azok a bizonytalansága is kulcsfontosságú paraméter az eredmények értékelésének szempontjából [97]. Másrészt a paraméterek sztenderd deviációja egyben a kísérleti adatok modellezésének eredményességét, vagyis az alkalmazott kísérleti adatok és kiértékelési eljárás helyességét is minősíti. Az $\Delta H^{o}, \Delta S^{o}$ és a $\Delta C_{p}$ paraméterek sztenderd deviációinak számítása érdekében a paraméterbecslést követően a súlyozott mintavariáláson alapuló ,jackknife” eljárást alkalmaztam [98]. A statisztikai módszer a paraméterbecsléshez felhasznált adathalmaznak a rendelkezésre álló adatpontok halmazából történő

\footnotetext{
${ }^{37}$ A kísérleti $y$ érték súlyozó tényezője: $w_{y}=1 / S_{y}$, ahol $S y$ az y érték sztenderd deviációja. A súlyozott

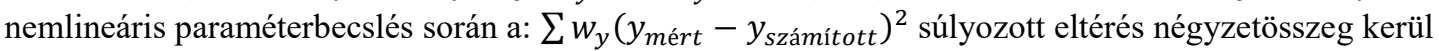
minimalizálásra a paraméterkészlet variálása mellett.
} 
szisztematikus vagy véletlenszerủen variálása általi feltöltésén alapul. A módszer egyik számomra fontos előnye, hogy a szükséges képletek viszonylag könnyen kódolhatók az általam alkalmazott Excel nevü táblázatkezelő VBA (Visual Basic Applications ${ }^{38}$ ) programozási nyelvével.

$\mathrm{Az}$ általam meghatározott termodinamikai adatok $\left(\Delta H^{o}, \Delta S^{o}\right.$ és a $\left.\Delta C_{p}\right)$ sztenderd deviációjának számításhoz készített VBA modulban tárolt parancs- és függvénysorozat a kísérleti adatpárok (négy különböző $\ln K_{a}$ vs. 1/T adatpár) nemlineáris paraméterbecslés alapú illesztését végzi el az 5.22. egyenlet alapján az adathalmaz variálása mellett. Az első illesztés során az összes ismert adatpár felhasználásra kerül, majd az ezt követő illesztések során rendre elhagyásra kerül az adathalmaz első, második, harmadik stb. adatpárja. Az eljárás végeredményeként az adatpárok számával egyenlő számú paraméterkészlet áll rendelkezésre, amelyek alapján egyszerủen számítható az egyes paraméterek szórása.

A 6. táblázat által összefoglalt állapotfüggvények előjelét és abszolút értékét elemezve további értékes információkhoz juthatunk a KYNA GluR1270-300 polipeptiddel funkcionalizált SPR szenzorfelületen végbemenő reverzibilis megkötődésének módját illetően. A kismolekulás hatóanyagok makromolekula alkotta receptorukhoz való kapcsolódását olyan másodlagos kötési módok határozzák meg, mint a hidrogénhíd-kötések, az elektrosztatikus kölcsönhatások, vagy a Van der Waals (más néven diszperziós) erök. A fentiekben vázolt eljárással meghatározott állapotfüggvények előjele és nagysága valamint egymáshoz viszonyított aránya elsődleges információt szolgáltat a kapcsolódás módjáról és feltételezett mechanizmusáról [99]. A negatív $\Delta H^{o}$ és $\Delta S^{o}$ változás a kötés során kialakuló van der Waals kölcsönhatást és hidrogén-hidat jelez, míg a két paraméter pozitív elöjele a kötésben hidrofób kölcsönhatás jelenlétére utal [100]. Ezeken kívül meghatározó szerepe van a $\Delta C_{p}$ elöjelének is, pozitív érték esetén elektrosztatikus kölcsönhatások, míg negatív érték esetén hidrofób hatások dominálnak a kötés kialakulása során [101].

A felsorolt másodlagos kötéstípusokon mellett figyelmet érdemel a mágneses rezonancia spektroszkópiai vizsgálatok által bizonyítottan [102] az aminosavak oldalláncai közötti kialakuló sóhíd típusú kötés, amely fontos szerepet játszik a fehérjék harmadlagos szerkezetének kialakulásában [103]. A sóhidak egyrészt hidrogénhíd-kötésü formának felelnek meg, de kötést kialakító partnerek formálisan ionos állapotúak. Amikor egy peptidlánc bázikus oldalláncú aminosavai semleges (neutrális) formában vannak jelen a hidrogénhíd-kötés kialakulása a kedvezményezett, de a kémiai környezet változása által

\footnotetext{
${ }^{38} \mathrm{https}: / /$ docs.microsoft.com/en-us/office/vba/api/overview/excel
} 
alternatív kölcsönhatásként a komplex, úgynevezett „sóhidas” elrendezés is kialakulhat, amelyet 20 - $25 \mathrm{~kJ} \mathrm{~mol}^{-1}$ kötési entalpia jellemez [104,105].

A KYNA GluR1 270-300 polipeptid funkcionalizált SPR szenzorfelületen végbemenő megkötődéséhez rendelhető $\Delta G^{\circ}$ negatív előjele bizonyítja, hogy a szenzor felületén a polipeptid fragmens és a KYNA alkotta kötési komplex képződése spontán folyamat. Az $\Delta H^{\circ}$ elöjele értelmében a kötési reakció exoterm folyamat, ahogyan azt korábban az adszorpció megközelítésü kiértékelési eljárás (5.3.3. fejezet) eredményeként kapott negatív izoszter adszorpciós hő jelezte. A folyamat során tapasztalt negatív $\Delta S^{\circ}$ értelmében a rendszer rendezetlenségének mértéke csökken miközben a KYNA molekulák elfoglalják a szenzor felületéhez rögzített polipeptid kötőhelyeit, mindeközben az entrópia tag abszolút értéke alatta marad az entalpia tag abszolút értékének, így a folyamat hajtóereje egyértelmüen az entalpia változása. Az együttesen negatív $\Delta H^{\circ}$ és $\Delta S^{\circ}$ értékek hidrogén-híd és elektrosztatikus kölcsönhatások létezésére engednek következtetni, amelyek a közel neutrális $(\mathrm{pH}=7,4)$ PBS közegben a KYNA deprotonált karboxilcsoportja és a 285-ös helyzetű arginin guanidinocsoportja között kialakuló sóhíd által értelmezhető. Utóbbi funkciós csoportot viszonylag erős bázis lévén $\left(p K_{a 2}=9,00\right)$ széles $p H$ tartományban pozitív töltés jellemzi, így a semleges kémhatású közegben protonált formában van jelen. A sóhíd típusú másodlagos kötés jelenlétét az 5.3.1. fejezetben bemutatott MD szimulációk is igazolják, mely alapján az elektrosztatikus kölcsönhatáson felül a KYNA megkötődéséhez benzolgyürüje és a polipeptid apoláros szakasza (,,apolar pocket”) közötti hidrofób kölcsönhatás is hozzájárul. Ennek a hidrofób kölcsönhatásnak a jelenlétére utal a negatív előjelü és jelenős abszolút értékü $\Delta C_{p}$ tag megjelenése. 


\subsection{AMPA receptort modellező (GluR1 231-259) polipeptid és KYNA kölcsönhatásának modellezése SPR szenzorfelületen}

\subsubsection{A szenzorfelület kialakítása, valamint a KYNA és GluR $1_{231-259}$ polipeptid alkotta kötési komplex keletkezését jellemzö sebességi állandók meghatározása}

Az AMPA receptor alegység és KYNA közötti kölcsönhatás SPR spektroszkópia alapú modellezésének következő kísérletsorozatában a GluR1 $1_{231-259}$ jelölésű és korábban már karakterizált polipeptiddel funkcionalizált szenzorfelületen vizsgáltam a hatóanyag megkötődésének kinetikáját és a kötés termodinamikai sajátságait. A szenzorfelület funkcionalizálását az 5.3.2. fejezetben bemutatott módon végeztem el, majd a KYNA koncentráció- és hőmérsékletfüggő megkötődésének vizsgálata során az 5.3.3. fejezetben foglaltakkal analóg módon jártam el. A funkcionalizálást követően $166,8 \pm 4,9 \mathrm{ng} \mathrm{\textrm {cm } ^ { - 2 }}$ adszorbeált tömeg jellemezte a GluR1231-259 polipeptiddel borított szenzorfelületet, amely lényegesen kisebb ${ }^{39}$ a korábbi vizsgálat során kapott 204,5 $\pm 2,4 \mathrm{ng} \mathrm{cm}^{-2}$ értéknél. Ezen méréssorozatban viszont a korábbinál részletesebb módon, hat eltérő hőmérsékleten sikerült rögzíteni a koncentrációfüggő szenzorgram sorozatokat. A 32. ábra A része szemlélteti reprezentatív módon a $25{ }^{\circ} \mathrm{C}$ hömérsékleten rögzített szenzorgramokat, amegyeknek szürke mezővel kiemelt asszociációs szakaszait a 32. ábra $\mathbf{B}$ részén látható modellgörbékkel illesztve határoztam meg a kötési folyamatot jellemző $k_{o b s}$ értékeket.
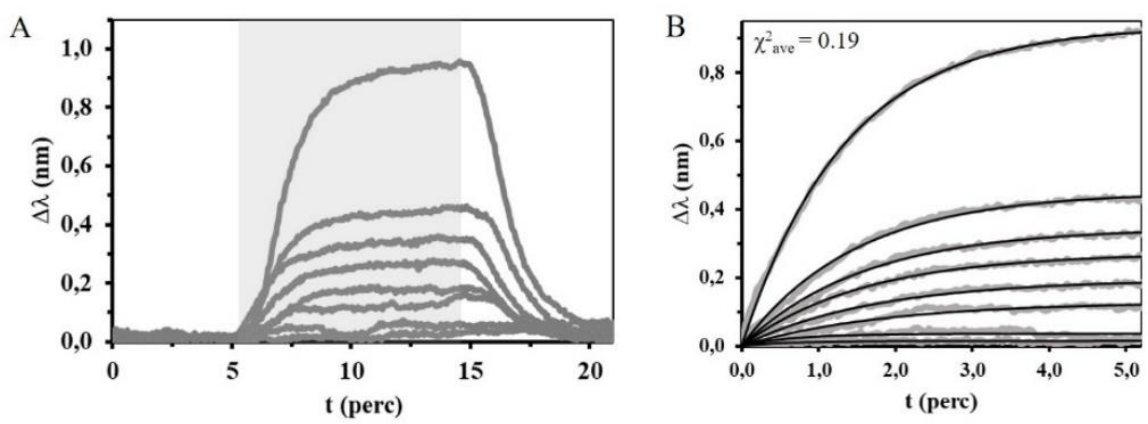

32. ábra: A KYNA GluR $1_{231-259}$ polipeptiddel funkcionalizált SPR szenzorfelületen, $25{ }^{\circ} \mathrm{C}$ hőmérsékleten végbemenő feldúsulását jellemző szenzorgramok (A) és pszeudo-elsőrendü sebességi egyenlettel (5.14.) illesztett modellgörbéik (B)

A nemlineáris paraméterbecslés után minden alkalmazott KYNA koncentráció és mérési hőmérséklet esetében rendelkezésre álló $k_{o b s}$ értékeket az 5.3.4 fejezetben bemutatottokkal

\footnotetext{
${ }^{39}$ A megismételt funkcionalizálás során, minthogy korlátozott mennyiség állt rendelkezésre a megtisztított polipeptidből, nem sikerült a korábbival azonos mértékben telíteni a szenzorfelületet, ám ez a kiértékelési eljárás által szolgáltatott eredményekre nem gyakorolt érdemleges hatást.
} 
analóg módon használtam fel $k_{a}$ és $k_{d}$ sebességi állandók meghatározására. A valós sebességi állandók meghatározása érdekében végzett lineáris regresszió sorozatot a 33. ábra grafikonjai szemléltetik.
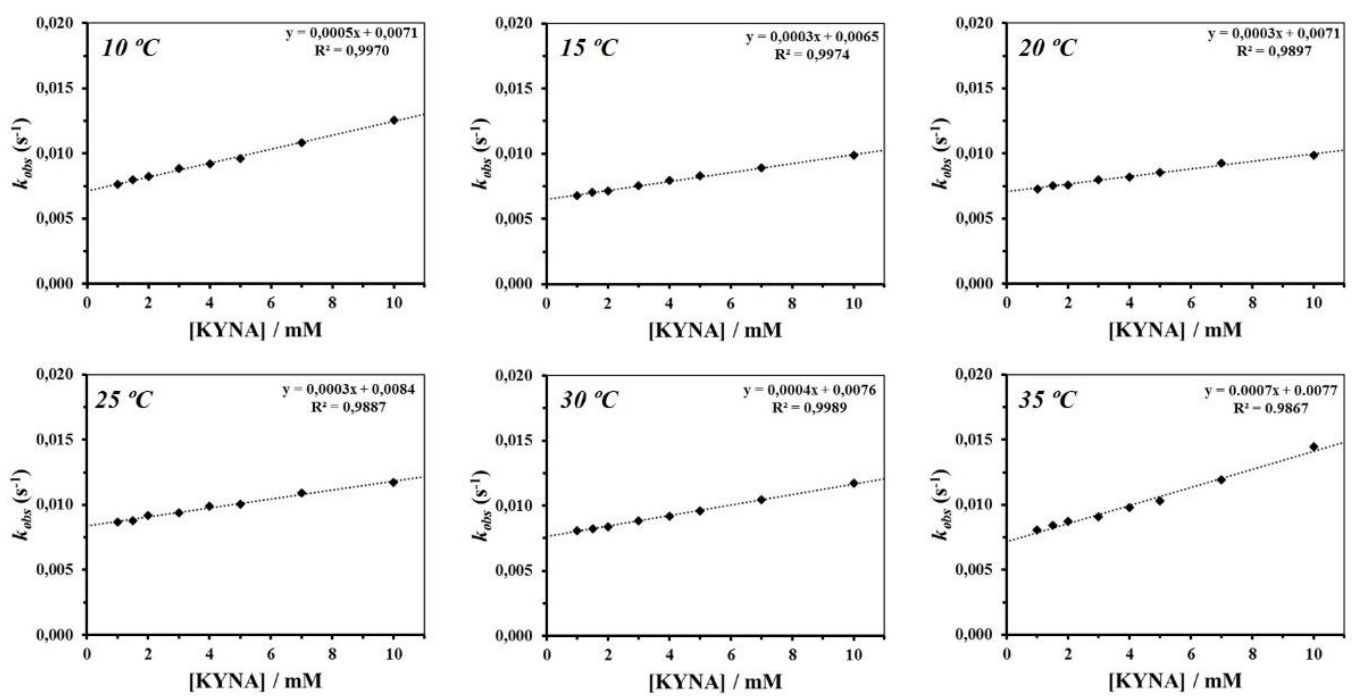

33. ábra: A KYNA és GluR1231-259 polipeptid alkotta kötési komplex kialakulását és disszociációját jellemző valós sebességi állandók meghatározása a $k_{o b s}$ koncetrációfüggésének (5.6. egyenlet) lineáris regressziója által

\subsubsection{A KYNA és az AMPA receptort modellezö GluR $1_{231-259}$ polipeptid alkotta kötési} komplex keletkezésének van't Hoff analizise

A GluR1 $231-259$ polipeptid és KYNA alkotta kötés komplex kialakulását és disszociációját jellemző szenzorgramok kinetikai modellezése által származtatott $K_{A}$ és $\Delta G$ értékeit, valamit ezek sztenderd deviációit és a van 't Hoff reláció alkalmazásához szükséges reciprok hőmérséklet és $\ln K_{A}$ értékeket utóbbiak szórásával együtt a 7. táblázat foglalja össze. A 7. táblázat adatkészlete alapján az 5.22. egyenlet felhasználásával végzett súlyozott nemlineáris paraméterbecslési eljárás eredményeként kapott $\mathrm{f}=\ln K_{A}(1 / \mathrm{T})$ függvényt pedig a 34. ábra szemlélteti. A 7. táblázat adatait személve azonnal megállapítható, hogy a KYNA GluR1 $231-259$ polipeptid funkcionalizált SPR szenzorfelületen végbemenő megkötődése a $\Delta G$ teljes hőmérséklettartományon negatív előjele által garantáltan spontán folyamat. A nemlineáris paraméterbecslésböl származó illesztési paraméterek rendre a következö értékeknek adódtak: $\Delta H^{o}=-42,79 \pm 5,73 \mathrm{~kJ} \mathrm{~mol}^{-1} ; \Delta S^{o}=$ $-0,1161 \pm 0,0197 \mathrm{~kJ} \mathrm{~mol}^{-1} \mathrm{~K}^{-1}$ és $\Delta C_{p}=-6,42 \pm 0,65 \mathrm{~kJ} \mathrm{~mol}^{-1} \mathrm{~K}^{-1}$. A termodinamikai adatok közül a $\Delta H^{\circ}$ előjele értelmében a KYNA és GluR1 $231-259$ polipeptid közötti kötési exoterm 
folyamat során jön létre, ahogyan azt a megelőző kísérletsorozat adszorpció megközelítésű kiértékelési eljárásának [58] eredményeként kapott negatív izoszter adszorpciós hő jelezte.

7. táblázat: A GluR1231-259 polipeptid és KYNA alkotta kötés komplex kialakulását jellemző szenzorgramok illesztése útján meghatározott termodinamikai paraméterek

\begin{tabular}{|c|c|c|c|c|c|c|c|c|c|c|}
\hline \multirow{2}{*}{$\frac{T(\mathrm{~K})}{283,15}$} & \multirow{2}{*}{$\frac{T^{-1}\left(\mathrm{~K}^{-1}\right)}{0,00353}$} & \multicolumn{3}{|c|}{$K_{A}\left(\mathrm{M}^{-1}\right)$} & \multicolumn{3}{|c|}{$\ln K_{A}$} & \multicolumn{3}{|c|}{$\Delta G\left(\mathrm{~kJ} \mathrm{~mol}^{-1}\right)$} \\
\hline & & 74,5 & \pm & 5,0 & 4,31 & \pm & 0,07 & $-10,15$ & \pm & 0,04 \\
\hline 288,15 & 0,00347 & 52,4 & & 4,2 & 3,96 & \pm & 0,08 & $-9,49$ & & 0,05 \\
\hline 293,15 & 0,00341 & 41,4 & $I$ & 5,0 & 3,72 & \pm & 0,12 & $-9,08$ & & 0,08 \\
\hline 298,15 & 0,00335 & 40,9 & $\perp$ & 5,2 & 3,71 & \pm & 0,13 & $-9,20$ & + & 0,08 \\
\hline 303,15 & 0,00330 & 53,0 & & 3,1 & 3,97 & \pm & 0,06 & $-10,01$ & & 0,04 \\
\hline 308,15 & 0,00325 & 87,8 & \pm & 6,9 & 4,47 & \pm & 0,08 & $-11,46$ & \pm & 0,05 \\
\hline
\end{tabular}

A folyamatot kísérő negatív $\Delta S^{\circ}$ értelmében a rendszer rendezetlenségének mértéke csökken azáltal, hogy a KYNA molekulák elfoglalják a szenzorfelületi kötőhelyeket. Minthogy az entrópia tag abszolút kisebb az entalpia tag abszolút értékénél a reverzibilis kötés entalpiakontrollált folyamat eredményeként alakul ki. A negatív $\Delta H^{\circ}$ és $\Delta S^{\circ}$ értékek a korábban vizsgált receptor modellhez (GluR1270-300) hasonló módon hidrogén-híd és elektrosztatikus kölcsönhatások jelenlétét valószínüsítik, amelyek a közel neutrális $(\mathrm{pH}=7,4)$ PBS közegben a KYNA deprotonált karboxilcsoportja és a 242-es (és/vagy 244-es) helyzetü lizin aminocsoportja között kialakuló sóhíd által értelmezhető.

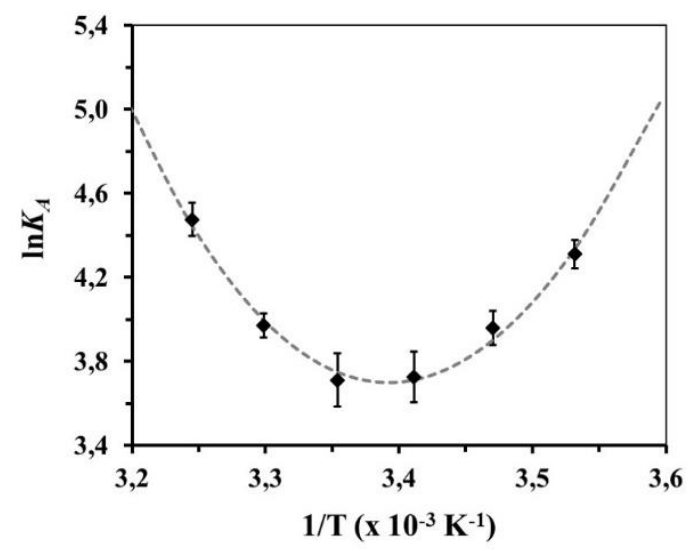

34. ábra: A GluR $1_{231-259}$ polipeptid és KYNA alkotta kötési komplex kialakulását jellemző szenzorgramok pszeudo-elsőrendü kinetikai modellezése során meghatározott $K_{A}$ értékek van 't Hoff reprezentációja 
Utóbbi funkciós csoportot bázikus sajátsága $\left(p K_{a 2}=9,12\right)$ révén az alkalmazott pH érték mellett protonált formában van jelen. A sóhíd típusú másodlagos kötést az 5.3.1. fejezetben bemutatott MD szimulációk is előjelezték, de a szimulációk értelmében az elektrosztatikus kölcsönhatáson felül a KYNA megkötődéséhez a benzolgyürüje és a polipeptid apoláros szakasza közötti hidrofób kölcsönhatás is hozzájárul. A hidrofób kölcsönhatás jelenlétének kísérleti bizonyítéka a negatív előjelü $\Delta C_{p}$ tag megjelenése.

\subsection{Szérum fehérjék (BSA, HSA) és KYNA kölcsönhatásának modellezése SPR szenzorfelületen}

\subsubsection{A KYNA szenzorfelületen immobilizált szérum fehérjéken (BSA, HSA) végbemenö reverzibilis kötödésének kinetikai vizsgálata}

Az AMPA receptor alegység mimetikumok (GluR1231-259 és GluR $1_{270-300)}$ és KYNA közötti kölcsönhatás SPR technika által szilárd/folyadék határfelületen kivitelezett modellezése és jellemzése során a következő kísérletsorozatban összehasonlító jellegü vizsgálatokat végeztem, BSA és HSA fehérjékkel-funkcionalizált SPR szenzorfelületen vizsgálva a KYNA megkötődését. A biomimetikus szenzorfelület kialakítását az 5.1.3. fejezetben bemutatott módon végeztem és eredményeként a korábbiakkal azonos minőségü szenzorfelülethez jutottam. Ezt követően a fehérjék irreverzibilis kötése által kialakított szenzor felület felett állandó összetételü PBS-t és különböző koncentrációjú, PBS közegü KYNA oldatokat $(\mathrm{c}=1,0 ; 1,5 ; 2,0 ; 3,0 ; 4,0 ; 5,0 ; 7,0$ és $10,0 \mathrm{mM})$ váltakozva áramoltattam. Az áramlási sebesség, ahogyan a vérszérum fehérjék arany felületre történő irreverzibilis rögzítése során, itt is minden esetben $50 \mu 1$ perc $^{-1}$ értéknek felelt meg.

A BSA-KYNA rendszer esetében 10 és $25 \mathrm{C}^{\circ}$ között négy hőmérsékleten rögzítettem a szenzorgram sorozatokat, míg a HSA-KYNA rendszer esetében 15 és $30 \mathrm{C}^{\circ}$ közötti hőmérséklet tartományban ismételtem meg a méréseket négy eltérő hőmérsékleten, így a feltételezhetően analóg receptor - ligandum kölcsönhatásról 10 és $30 \mathrm{C}^{\circ}$ közötti hőmérséklet tartományban sikerült információt gyüjteni. A BSA által funkcionalizált szenzorfelületen végzett szenzorikai vizsgálatok eredményeit reprezentatív módon a 35. ábra $\mathbf{A}$ része szemlélteti, amely mellett a $\mathbf{3 5}$. ábra $\mathbf{B}$ része illusztrálja a szenzorgramok pszeudo-elsőrendű sebeségi egyenlettel (5.14.) történő illesztését. A HSA felhasználásával módosított szenzorfelületen végzett SPR mérések eredményét reprezentatív módon a $\mathbf{3 6}$. ábra $\mathrm{A}$ része szemlélteti, amely mellett a 36. ábra $\mathbf{B}$ részén feltüntetésre kerültek a szenzorgramok pszeudo-elsőrendü sebeségi egyenlettel (5.14.) történő illesztése során generált 
modellgörbék. A szenzorgramokból megállapítható, hogy az AMPA receptor alegység mimetikumok esetében tapasztaltakhoz hasonlóan a KYNA reverzibilis módon kötődik a vizsgált szérum fehérjékhez is, minthogy utóbbiak esetében a disszociációs fázist követően a szenzorjel szintén az alapvonalnak megfelelő értéket veszi fel.
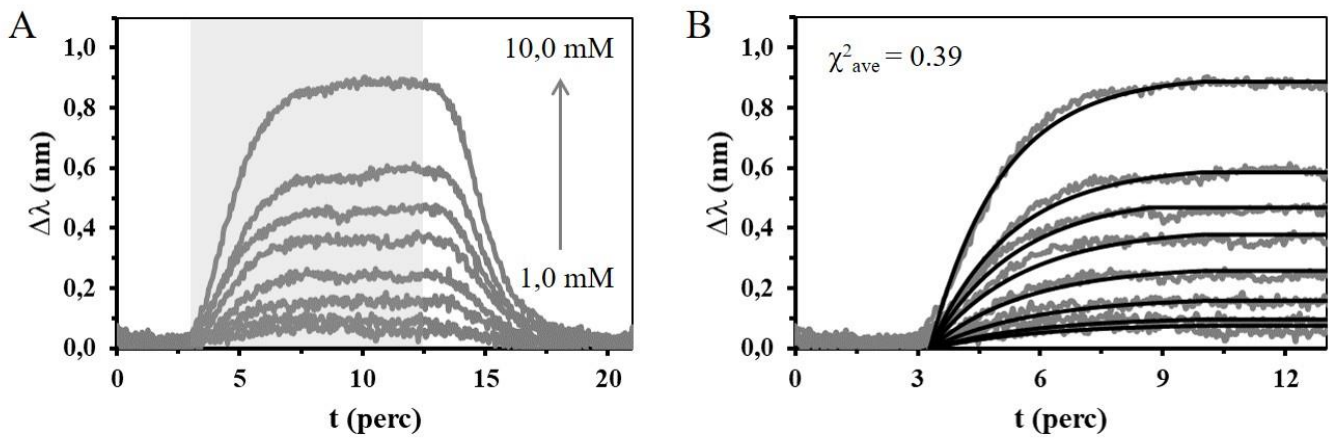

35. ábra: SPR szenzor felülethez rögzített BSA és KYNA közötti kölcsönhatás vizsgálata során $25 \mathrm{C}^{\circ}$ hömérsékleteken 1,0 és 10,0 mM közötti analit koncentrációtartományban rögzített szenzorgramok (A) és a pszeudo-elsőrendü sebeségi egyenlettel (5.14.) illesztett modellgörbéik (B)
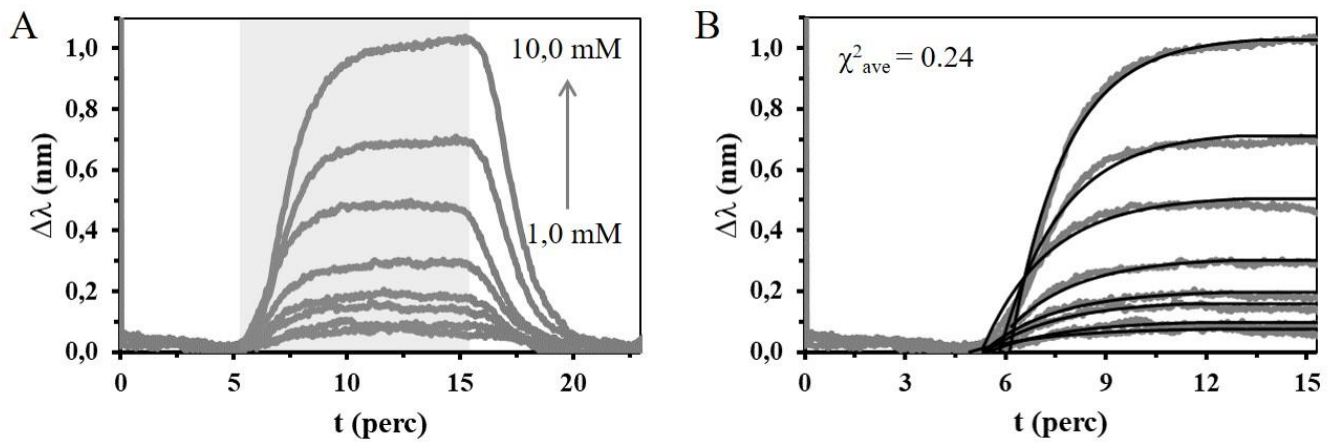

36. ábra: SPR szenzor felülethez rögzített HSA és KYNA közötti kölcsönhatás vizsgálata során $25 \mathrm{C}^{\circ}$ hömérsékleteken 1,0 és 10,0 mM közötti analit koncentrációtartományban rögzített szenzorgramok (A) és a pszeudo-elsőrendű sebeségi egyenlettel (5.14.) illesztett modellgörbéik (B)

Miután az egyes KYNA koncentrációkhoz rendelhető szenzorgram illesztését (5.14. egyenlet alapján) minden hőmérsékletre vonatkozó elvégeztem, rendelkezésre állt a $k_{o b s}$ értékekből és hozzájuk rendelhető KYNA koncentrációkból álló adathalmaz, amelyből a 5.6. egyenlet alapján egyszerü lineáris regresszió útján meghatároztam az egyes hőmérsékletre vonatkozó valós sebességi állandók ( $k_{a}$ és $k_{d}$ ) értékét és sztenderd deviációját. A lineáris 
regressziós eljárás alapjául szolgáló adatsorokat és az 5.6. egyenlet alapján illesztett egyeneseket a 37. ábra szemlélteti.
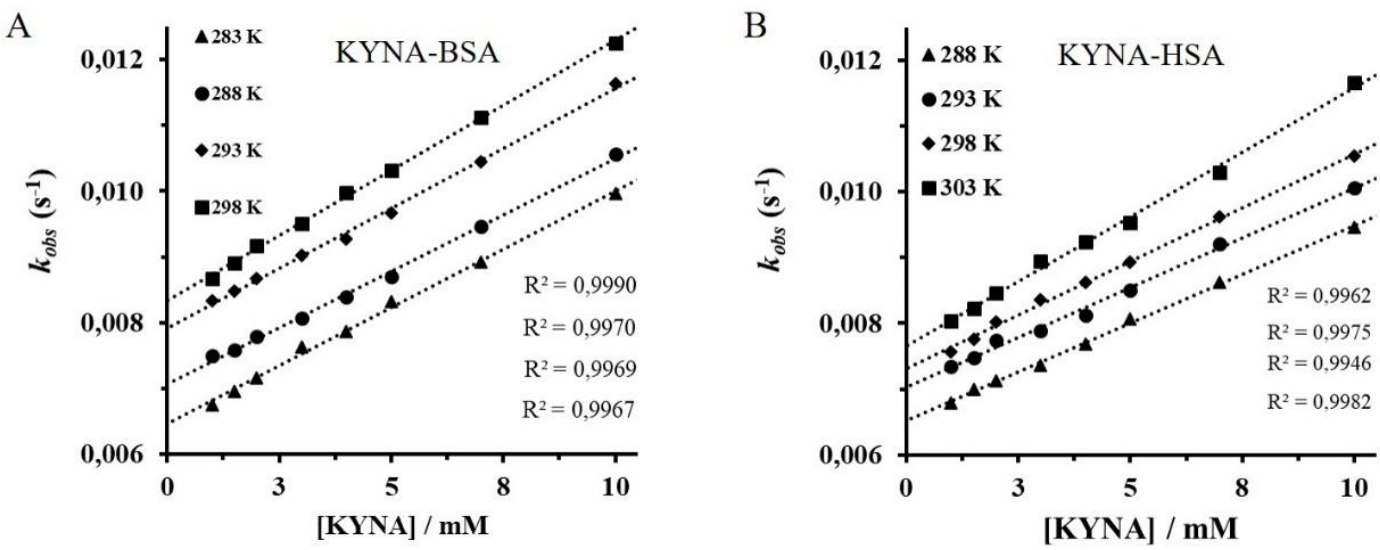

37. ábra: A KYNA és BSA (A) valamint a KYNA és HSA (B) alkotta kötési komplex kialakulását és disszociációját jellemző valós sebességi állandók meghatározása a $k_{o b s}$ koncentrációfüggésének (5.6. egyenlet) lineáris regressziója által

\subsubsection{A KYNA szenzorfelületen immobilizált szérum fehérjéken (BSA, HSA) végbemenö reverzibilis kötödésének Van’t Hoff analízise}

A termodinamikai paraméterek meghatározása érdekében első lépésként a valós sebességi állandók hányadosaként a $K_{A}$ értékét határoztam meg, ezek értékét a 8. táblázat foglalja össze. Az egyensúlyi állandók ismeretében az 5.18. egyenlet alapján közvetlen számítható a kötési folyamathoz rendelhető $\Delta G$ értéke, amelynek negatív előjele bizonyítja, hogy a kötés kialakulása minden hőmérsékleten és mindkét szérum fehérje esetében spontán folyamat eredményeként alakulhat ki.

8. táblázat: A szérum fehérjék és KYNA alkotta kötés komplex kialakulását jellemző szenzorgramok illesztése útján meghatározott $K_{A}$ paraméterek értékek és ezek alapján számított $\Delta G$ értékek

\begin{tabular}{ccccc}
\hline & \multicolumn{2}{c}{ BSA-KYNA } & \multicolumn{2}{c}{ HSA-KYNA } \\
\cline { 2 - 5 }$T(\mathrm{~K})$ & $K_{A}\left(\mathrm{M}^{-1}\right)$ & $\Delta G\left(\mathrm{~kJ} \mathrm{~mol}^{-1}\right)$ & $K_{A}\left(\mathrm{M}^{-1}\right)$ & $\Delta G\left(\mathrm{~kJ} \mathrm{~mol}^{-1}\right)$ \\
\hline 283,15 & $60 \pm 4$ & $-9,62 \pm 0,04$ & n.i. & n.i. \\
288,15 & $52 \pm 3$ & $-9,48 \pm 0,04$ & $49 \pm 2$ & $-9,34 \pm 0,03$ \\
293,15 & $49 \pm 3$ & $-9,50 \pm 0,04$ & $46 \pm 4$ & $-9,36 \pm 0,06$ \\
298,15 & $51 \pm 2$ & $-9,73 \pm 0,02$ & $48 \pm 3$ & $-9,59 \pm 0,04$ \\
303,15 & n.i. & n.i. & $55 \pm 4$ & $-10,10 \pm 0,05$ \\
\hline
\end{tabular}


A 8. táblázat adatai alapján, a $K_{A}$ hőmérsékletfüggésének ismeretében a van 't Hoff egyenlet 5.22. formája alapján végzett súlyozott nemlineáris paraméterbecslési eljárás eredményeként határoztam meg a KYNA szenzorfelületen immobilizált BSA és HSA fehérjéken végbemenő reverzibilis kötődéséhez rendelhető $\Delta H^{o}, \Delta S^{o}$ és $\Delta C_{p}$ értékeit. A felsorolt állapotfüggvények megismeréséhez végzett paraméterbecsléshez van 't Hoff reprezentációban ábrázolt adatokat és az 5.22. egyenlet alapján illesztett modellgörbéket a 38. ábra szemlélteti.
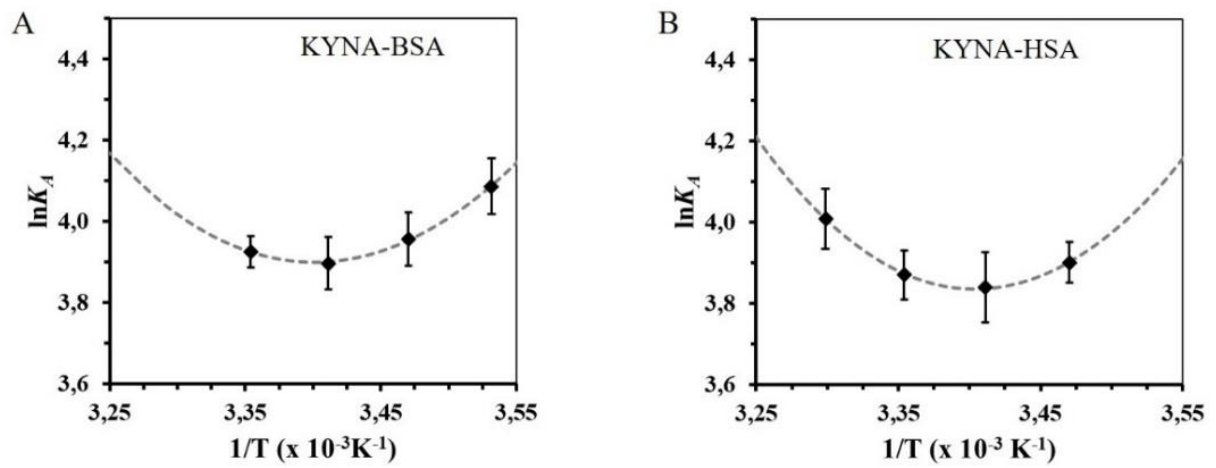

38. ábra: A KYNA és BSA (A) valamint a KYNA és HSA (B) alkotta kötési komplex kialakulását jellemző szenzorgramok pszeudo-elsőrendü kinetikai modellezése során meghatározott $K_{A}$ értékek van ’t Hoff reprezentációja

A nemlineáris paraméterbecslés útján számított termodinamikai mennyiségek standard deviációjának meghatározásához ebben az esetben is súlyozott minta variáláson alapuló, úgynevezett ,jackknife” statisztikai módszert alkalmazásával számítottam a 9. táblázat által összefoglalt $\Delta H, \Delta S$ és $\Delta C_{p}$ értékek sztenderd deviációit.

9. táblázat: A szérum fehérjék és KYNA alkotta kötés komplex kialakulását kísérő $\Delta H^{0}$, $\Delta S^{0}$ és $\Delta C_{p}$ értékek

\begin{tabular}{l|ccc}
\hline & $\Delta H^{0}\left(\mathrm{~kJ} \mathrm{~mol}^{-1}\right)$ & $\Delta S^{0}\left(\mathrm{~kJ} \mathrm{~mol}^{-1} \mathrm{~K}^{-1}\right)$ & $\Delta C_{p}\left(\mathrm{~kJ} \mathrm{~mol}^{-1} \mathrm{~K}^{-1}\right)$ \\
\hline BSA-KYNA & $-1,94 \pm 0,25$ & $0,0258 \pm 0,0008$ & $-2,17 \pm 0,18$ \\
HSA-KYNA & $-1,87 \pm 0,22$ & $0,0255 \pm 0,0008$ & $-2,95 \pm 0,09$ \\
\hline
\end{tabular}

A 9. táblázat adatait szemlélve megállapítható, hogy az egyaránt negatív entalpia és entrópia tag $\left(-T \Delta S^{\circ}\right)$ értelmében a KYNA szenzorfelületen immobilizált szérum fehérjékhez való kötődése entalpia- és entrópia-kontrollált folyamat eredménye. A $\Delta H^{\circ}$ és $\Delta S^{\circ}$ értékek eltérő előjele arra utalhat, hogy a negatív $\Delta H^{\circ}$ és pozitív $\Delta S^{\circ}$ értékeknek megfelelően a hidrogénhidak jelenlétén túlmenően hidrofób effektus is hozzájárul a fehérjék és a KYNA alkotta 
kötési komplex kialakulásához, amelyet a negatív elöjelü $\Delta C_{p}$ tag megjelenése is megerősít. Mindezek mellett a szérum fehérjék és KYNA alkotta kötés komplex kialakulásának termodinamikai jellemzőit, a 39. ábra energiadiagramja alapján összevetve az AMPA receptor mimetikumok esetében meghatározott értékekkel megállapítható, hogy utóbbiak esetében sokkalta specifikusabb kölcsönhatás eredményként alakul ki a reverzibilis kötés, mit a BSA és HSA esetében.

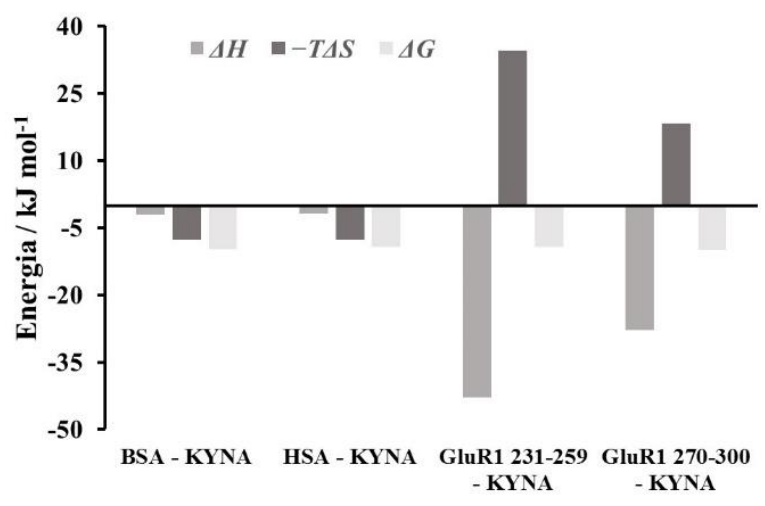

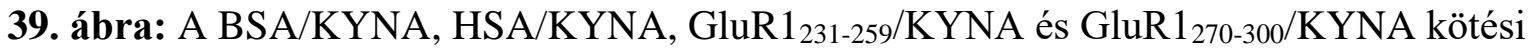
komplexek kialakulását jellemző termodinamikai jellemzők összehasonlítása

Habár a kötési folyamathoz rendelhető $\Delta G^{\circ}$ közel azonos nagyságú minden vizsgált rendszer esetében, az AMPA receptor mimetikumok és KYNA alkotta receptor-ligandum komplexek entalpia és entrópia tagjának változása nagy és ellentétes irányú. Utóbbi kombináció a receptor-ligandum komplex összetett szerkezeti változására utal, amely során a másodlagos kötéstípusok együttese eredményezi a komplex módosulást. Kombinatorikai megfontolás lapján belátható, hogy többféle gyenge kölcsönhatás jelenlétében kisebb annak az állapotnak a valószínűsége, amely esetében minden gyenge kötés egyszerre bomlik fel. A kölcsönhatás specifikusságának a szempontjából tehát a nagyobb számú és eltérö kölcsönhatásból felépülő kötésrendszer előnyösebb.

\subsubsection{A KYNA szérum fehérjéken (BSA, HSA) végbemenö kötödésének oldatfázisú kalorimetriás vizsgálata}

Az összehasonlító vizsgálatok kiegészítő kísérletsorozataként a szérum fehérjék és KYNA közötti kölcsönhatás SPR technika által szilárd/folyadék határfelületen kivitelezett modellezése és jellemzése során meghatározott termodinamikai jellemzők értékének helytállóságát oldatfázisban kivitelezett ITC mérések által is igyekeztem megerösíteni. A kalorimetriás mérések során a korábbi vizsgálatokkal azonos módon PBS-ben oldott 50,0 
$\mu \mathrm{M}$ koncentrációjú fehérje mintákat és 2,0 mM koncentrációjú, szintén puffer közegü KYNA oldatokat használtam fel. A titrációs lépések kivitelezése során a minta cellába töltött fehérje oldatához került adagolásra a KYNA oldata 10-10 $\mu \mathrm{L}$-es térfogat egységekben, miközben a berendezés regisztrálta a 40. ábra $\mathbf{A}$ és $\mathbf{B}$ részén feltüntetett kalorimetriás görbéket $(\mathrm{f}=\mathrm{d} Q / \mathrm{dt}(\mathrm{t}))$, amelyek alapján az Origin Microcal 7.1. szoftvere integrációs úton kalkulálta a fekete pontokkal jelölt entalpogramokat ( $\mathrm{f}=\Delta \mathrm{H}\left(n_{x}\right)$ ). Az említett szoftver többféle matematikai modell alapján képes illeszteni a kísérleti adatokat a kötési folyamathoz rendelhető termodinamikai paraméterek meghatározása érdekében. A 40. ábra A és B részén feltüntetett entalpogramok Origin Microcal 7.1. szoftver általi modellezése azonban nem eredményezett elfogadható minőségü illesztést, így kiértékelés során a modellfüggetlen Boltzmann egyenlet ${ }^{40}$ alábbi 5.23. formája alapján végeztem el a nemlineáris paraméterbecslési eljárást.

$$
\Delta H_{I T C}=a_{1} \frac{a_{2}-a_{1}}{1+\exp \left[n_{x^{-}} a^{a_{4}} / a_{3}\right]}
$$

Az 5.23. egyenlet $a_{1}, a_{2}, a_{3}$ és $a_{4}$ illesztési paraméterei alapján a hőjelenséget kiváltó folyamat látszólagos termodinamikai jellemzői ( $n_{x}$ és $\left.\Delta H_{o b s}\right)$ a 4.2.3. fejezetben bemutatott 9. ábra $\mathbf{B}$ részén vázolt megfontolások alapján számíthatók.
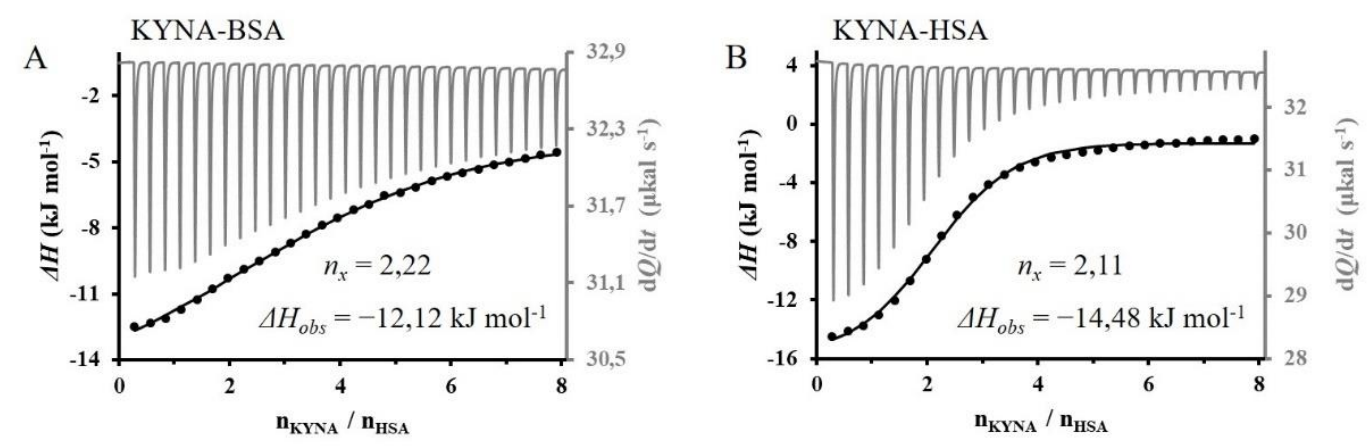

40. ábra: A KYNA és BSA (A) valamint a KYNA és HSA (B) alkotta kötési komplex kialakulását jellemző kalorimetriás görbék (szürke vonal) és entalpogramok (fekete pontok) valamint az entalpogramok 5.23. egyenlettel illesztett modellgörbéi

A 40. ábra A és $\mathbf{B}$ részén feltüntetett entalpogramok alapján meghatározott és az ábrán szereplö $n_{x}$ és $\Delta H_{o b s}$ értékek alapján megállapítható, hogy az ITC technika az SPR-alapú számításokkal azonos exoterm folyamatként azonosítja a szérum fehérjék és KYNA közötti kötés kialakulását, ám lényegesen nagyobb entalpiaváltozást rendel a folyamathoz.

\footnotetext{
${ }^{40}$ https://www.originlab.com/doc/Origin-Help/Boltzmann-FitFunc
} 


\section{6. Összefoglalás}

A modernkori gyógyszerkutatási fejlesztésekhez elengedhetetlen a receptorligandum típusú, valamint a fehérje-gyógyszermolekula kölcsönhatások mechanizmusának minél alaposabb megismerése, melyhez az elmúlt évtizedekben az elektronikai és az informatika háttér rohamos fejlődésével együtt, egyre nagyobb számban jelennek meg a piacon korszerü méréstechnikák. A molekuláris kölcsönhatásokat szilárd/folyadék határfelületen vizsgáló ,jelölésmentes” eljárások közül az SPR spektroszkópia egyre szélesebb körben alkalmazott kutatási módszerré vált. Hazai kutatóhelyek tekintetében az említett szenzortechnika nem tekinthető széles körben ismert és alkalmazott eljárásnak. Az SPR spektroszkópia révén a szenzor felületéhez kötött és a szenzor feletti térrészben áramló vegyületek közötti kölcsönhatás kvalitatív és kvantitatív megismerésére adódik lehetőség. Az eljárás valós idejü detektálásának köszönhetően a kölcsönhatások kinetikai vizsgálata is lehetséges, de számos korszerü SPR berendezésben, a szenzor felület és a mikrofluidikai felépítmény termosztálhatósága következtében, a kölcsönhatás termodinamikai paramétereinek meghatározása is könnyedén kivitelezhető.

Kutatócsoportunkban az SPR spektroszkópiai vizsgálatok 2012 óta egyre meghatározóbb szerepet kaptak, de a csoportunkban készült doktori értekezések sorában jelen dolgozat az első, amely makromolekulák és kismolekulás hatóanyagok közötti kölcsönhatások SPR méréstechnika általi modellezését mutatja be.

Doktori munkám során kapott eredményeket az alábbiakban foglalom össze:

Sikeresen alkalmaztam az SPR méréstechnikát kismolekulák molekuláris felületigényének és felületi orientációjának meghatározására, míg fehérjék esetén az említett paraméterek értéke becsülhető. Monomolekuláris borítottságot feltételezve a Cys, Cys-Trp és GSH esetén az arany felületen adszorbeált anyagmennyiségek ismeretében 0,32;0,47 és 0,62 $\mathrm{nm}^{2}$ molekuláris felületigény értékeket határoztam meg az említett molekulák megfelelő sorrendjében. A Cys és GSH vonatkozásában az adatok jó egyezést mutattak független QCM méréstechnika által szolgáltatott adatokkal $\left(0,30\right.$ és $\left.0,52 \mathrm{~nm}^{2}\right)$. A kismolekulák mellett monomolekuláris borítottságot feltételezve a BSA, HSA és LYZ fehérjék esetén, hasonló mérési és kiértékelési eljárás mellett, 171,5; 173,0 és 21,9 nm² molekuláris felületigény értékek adódtak. A független SAXS vizsgálatok révén a fehérjékre meghatározott "maximális térbeli kiterjedés" ( $\left.D_{\max }\right)$ értékek $(8,4 ; 8,7$ és 4,8 nm) figyelembevételével igazolhatóvá vált a fehérjék alkotta határfelületi réteg SPR-alapú adszorpciós modelljének realitása. 
Mindezek mellett, egy BSA/IBU mag-héj szerkezetü, kolloidális gyógyszerhordozó rendszer tervezéséhez hozzájárulva a hordozó fehérje és a hatóanyag közötti kölcsönhatás kvantitatív viszonyait tanulmányoztam szilárd/folyadék határfelületen. A regisztrált szenzorgramok pszeudo-elsőrendű kinetikai modellel történő illesztését lehetővé tévő táblázatkezelő alapú eljárást dolgoztam ki és azt eredményesen alkalmaztam a szenzorfelületen kialakuló kötési komplex keletkezését és bomlását jellemző sebességi állandók meghatározására. A szenzorgramok illesztéséböl meghatározásra került $\mathrm{k}_{a}=56,4$ $\pm 4,4 \mathrm{dm}^{3} \mathrm{~mol}^{-1} \mathrm{~s}^{-1}$ és $k_{d}=0,022 \pm 0,019 \mathrm{~s}^{-1}$ sebességi állandó értékek hányadosából az adott mérési hőmérsékletre vonatkozó egyensúlyi állandó érték $K_{A}=2,51 \times 10^{3} \pm 2,00 \times 10^{2} \mathrm{dm}^{3}$ mol $^{-1}$ értéknek adódott. A szilárd/folyadék határfelületen kivitelezett SPR-alapú és a kinetikai megközelítést alkalmazó kiértékelés eredményét megerősítettem oldatfázisú ITC vizsgálattal, ahol az egyensúlyi állandó értékére hasonló adatot kaptam $\left(K_{A}=2,47 \times 10^{3} \pm\right.$ $5,33 \times 10^{1} \mathrm{dm}^{3} \mathrm{~mol}^{-1}$ érték).

Munkám fő gerincét az AMPA receptor 1-es alegységét modellező polipeptidek (GluR1 270-300 és GluR1 231-259) és a KYNA kölcsönhatásának modellezése jelentette SPR szenzorfelületen. Igazoltam a GluR $1_{270-300}$ polipeptid arany szenzorfelületen történő megkötődése révén kialakult monomolekulás borítottságot feltételező adszorpciós rétegben a polipeptid vertikális felületi orientációját, melyet független molekuladinamikai számolások és AFM mérések eredményei is alátámasztanak. Meghatároztam a KYNA GluR1270-300 polipeptid rétegen mérhető szorpciós izotermáit 4 különböző hőmérsékelten. Az izotermák illesztése által meghatározott függvények hőmérsékletfüggését felhasználva számítottam az izoszter adszorpciós hö változását a KYNA felületi borítottságának függvényében. Az izoszter entalpiaváltozás felületi borítottságtól való függését elemezve megállapítható, hogy a szenzorfelületen az 1:1 sztöchiometriájú kötési komplex képződése kedvezményezett.

A KYNA és immobilizált GluR $1_{270-300}$ alegység modell közötti kölcsönhatás neutrális közegben $(\mathrm{pH}=7,4)$ rögzített szenzorgramjainak pszeudo-elsőrendü közelítésü kinetikai modellel történő, diszkrét és globális illesztése alapján meghatároztam a látszólagos sebességi állandók értékét. A látszólagos sebességi állandók koncentrációfüggése alapján számítottam a kötési komplex kialakulását és bomlását jellemző valós sebességi állandók értékét, végül utóbbiak ismeretében a folyamat egyensúlyi állandóját. A KYNA GluR1270-300 polipeptiddel funkcionalizált SPR szenzorfelületen való reverzibilis kötődését jellemző egyensúlyi állandó hőmérsékletfüggésének van 't Hoff analízise révén az említett paraméter sztenderd deviációjával súlyozott nemlineáris illesztése 
útján meghatároztam a folyamathoz rendelhető entalpia- $\left(\Delta \mathrm{H}^{\circ}=-27,91 \pm 5,27 \mathrm{kJmol}^{-1}\right)$, entrópia- $\left(\Delta \mathrm{S}^{\circ}=-60,33 \pm 17,95 \mathrm{~J} \mathrm{~mol}^{-1} \mathrm{~K}^{-1}\right)$ és hőkapacitás változás $\left(\Delta \mathrm{C}_{\mathrm{p}}=-1,28 \pm 0,54 \mathrm{~kJ}\right.$ $\mathrm{mol}^{-1} \mathrm{~K}^{-1}$ ) értékeket. A számított termodinamikai paraméterek előjele és nagysága alapján megállapítottam, hogy a hatóanyag entalpia kontrolált megkötődése elektrosztatikus és hidrogénhíd kötések révén jöhet létre, amelyek a molekuladinamikai számítások alapján is jósolt sóhíd ( $\left.\mathrm{ARG}_{285}-\mathrm{KYNA}\right)$ jelenlétét igazolják. A sóhíd a neutrális közegben $(\mathrm{pH}=7,4)$ szolvatált GluR1 270-300 polipeptidben 285-ös helyzetben található arginin pozitív töltésü guanidino-csoportja és a KYNA deprotonált karboxilcsoportja között alakulhat ki. A MD szimulációk értelmében ezen felül a KYNA megkötődéséhez benzolgyürüje és a polipeptid apoláros szakasza közötti hidrofób kölcsönhatás is hozzájárul, amelynek kísérleti úton származtatott bizonyítéka a negatív előjelű $\Delta C_{p}$ tag megjelenése.

A KYNA GluR1231-259 polipeptiddel funkcionalizált SPR szenzorfelületen való reverzibilis kötődését jellemző egyensúlyi állandók hőmérsékletfüggésének van 't Hoff analízise során az előzőekben alkalmazott paraméterbecslési eljárás útján meghatároztam a folyamathoz rendelhető entalpia- és entrópia- és hőkapacitás változás értékét, melyek rendre $\Delta H^{o}=-42,79 \pm 5,73 \mathrm{~kJ} \mathrm{~mol}^{-1} ; \Delta S^{o}=-11,61 \pm 0,0197 \mathrm{~J} \mathrm{~mol}^{-1} \mathrm{~K}^{-1}$ és $\Delta C_{p}=-6,42 \pm 0,65 \mathrm{~kJ}$ $\mathrm{mol}^{-1} \mathrm{~K}^{-1}$. Megállapítottam, hogy a KYNA reverzibilis kötődése entalpia-kontrollált folyamat eredménye és a negatív $\Delta H^{\circ}$ és $\Delta S^{\circ}$ értékek a korábbi modellhez (GluR $1_{270-300}$ ) hasonlóan hidrogén-híd és elektrosztatikus kölcsönhatás jelenlétét valószínüsítik, amelyek pH =7,4 esetén a KYNA deprotonált karboxilcsoportja és a 242-es (és/vagy 244-es) helyzetü lizin protonált aminocsoportja között kialakuló sóhíd által értelmezhető.

A KYNA szérum fehérjékkel (BSA, HSA)-funkcionalizált SPR szenzorfelületen való reverzibilis kötődését jellemző egyensúlyi állandók hőmérsékletfüggésének van 't Hoff analízise során meghatároztam a folyamathoz rendelhető entalpia- és entrópia- és hőkapacitás változás értékét, melyek a BSA esetén $\Delta H^{o}=-1,94 \pm 0,25 \mathrm{~kJ} \mathrm{~mol}^{-1} ; \Delta S^{o}=0,025$ $\pm 0,0008 \mathrm{~J} \mathrm{~mol}^{-1} \mathrm{~K}^{-1}$ és $\Delta C_{p}=-2,17 \pm 0,18 \mathrm{~kJ} \mathrm{~mol}^{-1} \mathrm{~K}^{-1}$, míg a HSA esetén $\Delta H^{o}=-1,87 \pm$ $0,22 \mathrm{~kJ} \mathrm{~mol}^{-1} ; \Delta S^{o}=0,0255 \pm 0,0008 \mathrm{~J} \mathrm{~mol}^{-1} \mathrm{~K}^{-1}$ és $\Delta C_{p}=-2,95 \pm 0,09 \mathrm{~kJ} \mathrm{~mol}^{-1} \mathrm{~K}^{-1}$ adódtak. Összehasonlítva a fehérjék (BSA, HSA) és a KYNA kapcsolódásának termodinamikai jellemzőit az AMPA receptor modellekre (GluR1 231-259 és GluR1270-300) kapott analóg eredményekkel megállapítottam, hogy polipeptidek esetében az SPR-alapú vizsgálat eredményei specifikusabb receptor-ligandum típusú kötés jelenlétét igazolják. 


\section{Summary}

Detailed knowledge of the mechanism of receptor-ligand-type and protein-drug molecule interactions is essential for modern pharmaceutical developments. In the past decades, with the rapid development of the electronics and information technology background, an increasing number of modern measuring techniques are available on the market. Among the "unlabeled" methods for studying molecular interactions at solid / liquid interfaces, the SPR spectroscopy has become a widely used measuring technique. Regarding to the Hungarian Research Institutes, the SPR technique is not a well-known and widely applied measuring apparatus. By using the SPR spectroscopy, the qualitative and quantitative analysis of the interaction between the surface-immobilized molecules and the compounds flowing over the sensor surface can be carried out. Thanks to the real-time detection, the kinetic evaluation of the studied interaction is possible. Moreover, for several SPR apparatus, through the temperature control of the sensor surface and the microfluidic setup the determination of the thermodynamic parameters of the interaction can also be accomplished.

In our research group, the SPR spectroscopy studies play a determinant role since 2012, but my PhD dissertation is the first, which presents the modelling of interactions between macromolecules and small molecules using SPR measurements. The results of my PhD work are summarized below:

I have successfully applied the SPR sensor technique to determine the cross-sectional area and the surface orientation of small molecules, while in the case of proteins the mentioned parameters can be estimated. Assuming monomolecular coverage, for Cys, CysTrp and GSH, in view of the adsorbed amount on gold surface the cross-sectional areas of 0.32; 0.47 and $0.62 \mathrm{~nm}^{2}$ have been determined, respectively. For Cys and GSH these data are in good agreement with the results of independent QCM technique $\left(0.30\right.$ and $\left.0.52 \mathrm{~nm}^{2}\right)$. Among small molecules, assuming monomolecular coverage for BSA, HSA and LYZ proteins in view of the adsorbed amount on gold surface the cross-sectional areas of 171.5; 173.0 and $21.9 \mathrm{~nm}^{2}$ have been calculated. Based on the results of SAXS studies the determined $\mathrm{D}_{\max }$ values $(8.4 ; 8.7$ and $4.8 \mathrm{~nm}$, respectively) clearly confirm the existence of a SPR-based acceptable adsorption model of the protein coated interface.

Moreover, contributing to the design of the BSA/IBU colloidal drug delivery system the quantitative characterization of the interaction between the carrier protein and the drug molecules have been carried out at solid/liquid interface. A spreadsheet-based evaluation 
method which allows the fitting of the registered sensorgrams by pseudo-first-order kinetic model has been developed. I successfully applied the developed evaluation procedure in order to the determine the association as well as the dissociation rate constants of the binding complex. The quotient of the determined $\mathrm{k}_{a}=56.4 \pm 4.4 \mathrm{dm}^{3} \mathrm{~mol}^{-1} \mathrm{~s}^{-1}$ and $k_{d}=0.022 \pm 0.019$ $\mathrm{s}^{-1}$ rate constants provided the equilibrium constant, which is $K_{A}=2.51 \times 10^{3} \pm 2.00 \times 10^{2}$ $\mathrm{dm}^{3} \mathrm{~mol}^{-1}$ at the given measuring temperature. The result of the SPR-based evaluation at solid / liquid interface and the evaluation using the kinetic approach was confirmed by solution phase and equilibrium ITC study, which provided similar data for $K_{A}\left(K_{A}=2.47 \mathrm{x}\right.$ $\left.10^{3} \pm 5.33 \times 10^{1} \mathrm{dm}^{3} \mathrm{~mol}^{-1}\right)$. Main part of my work was the modelling of the interaction between 1 subunit of AMPA receptor polypeptides (GluR1270-300 és GluR1231-259) and KYNA on SPR sensor surface. Assuming monomolecular coverage, the vertical surface orientation of the polypeptide in the adsorption layer on gold sensor surface has been verified. This assumption is confirmed by independent molecule dynamic calculations and AFM studies. The sorption isoterms of KYNA on GluR1 270-300 polypeptide layer have been determined at four different temperatures. Using the temperature-dependence of the functions determined by fitting of the isotherms, I calculated the change in the isosteric adsorption heat as a function of the surface coverage of KYNA. Analyzing the dependence of the isosteric enthalpy change on the surface coverage, it can be concluded that the formation of the $1: 1$ stoichiometric binding complex on the sensor surface is beneficial.

The apparent rate constants of the binding complex have been determined via the discrete and global fitting of the registered sensorgrams of the interaction between KYNA and the immobilized GluR $1_{270-300}$ fragment model at neutral medium $(\mathrm{pH}=7.4)$ by using pseudo first order kinetic model. Based on the concentration-dependence of the apparent rate constants the real rate constants of the formation and decomposition of the binding complex have been calculated. The enthalpy-, entropy- and heat capacity changes of the reversible interaction of KYNA with GluR1 270-300 polypeptide-functionalized SPR sensor surface have been determined via the van't Hoff analysis of the temperature-dependence of the equilibrium constant by using non-linear fitting. The calculated parameters are $\Delta \mathrm{H}^{\circ}=-27.91$ $\pm 5.27 \mathrm{~kJ} \mathrm{~mol}^{-1}, \Delta \mathrm{S}^{\circ}=-60.33 \pm 17.95 \mathrm{~J} \mathrm{~mol}^{-1} \mathrm{~K}^{-1}$ and $\Delta \mathrm{C}_{\mathrm{p}}=-1.28 \pm 0.54 \mathrm{~kJ} \mathrm{~mol}^{-1} \mathrm{~K}^{-1}$, respectively. Based on the sign as well as the values of the determined thermodynamic parameters it can be concluded that the enthalpy-controlled binding of the KYNA can be assumed via electrostatic and hydrogen bonds. Salt bridge is formed between the positively charged arginin side chain of GluR $1_{270-300}$ polypeptide and the negatively charged carboxyl group of KYNA, which is confirmed by molecule dynamic calculations as well. The MD 
simulated binding positions besides the forming a salt bridge found a hydrophobic interaction between the KYNA benzene ring and the a nearby apolar pocket of polypeptide, which was proven by the negative sign of the experimental $\Delta C_{p}$ value.

The apparent rate constants of the binding complex have been determined at six different temperatures via the discrete fitting of the registered sensorgrams of the interaction between KYNA and the immobilized GluR1 $1_{231-259}$ fragment model at neutral medium ( $\mathrm{pH}=$ $7,4)$ by using pseudo first order kinetic model. Based on the concentration-dependence of the apparent rate constants the real rate constants of the formation and decomposition of the binding complex have been calculated. The enthalpy-, entropy- and heat capacity changes of the reversible interaction of KYNA with GluR $1_{231-259}$ polypeptide-functionalized SPR sensor surface have been determined via the van't Hoff analysis of the temperaturedependence of the equilibrium constant by using non-linear fitting. The calculated parameters are $\Delta H^{o}=42,79 \pm 5,73 \mathrm{~kJ} \mathrm{~mol}^{-1} ; \Delta S^{o}=-11,61 \pm 0,0197 \mathrm{~J} \mathrm{~mol}^{-1} \mathrm{~K}^{-1}$ and $\Delta C_{p}=$ $6,42 \pm 0,65 \mathrm{~kJ} \mathrm{~mol}^{-1} \mathrm{~K}^{-1}$. It was found that, the reversible binding of KYNA is the result of an enthalpy-controlled process. Similar to the previously studied GluR1270-300, the negative signs of the $\Delta H^{\circ}$ and $\Delta S^{\circ}$ strongly refer the presence of hydrogen bonds and electrostatic interactions, which can be interpreted by the salt bridge formed between the deprotonated carboxyl group of KYNA and the protonated amino group at position 242 (and/or position of 244) of lysine. The enthalpy-, entropy- and heat capacity changes of the reversible interaction of KYNA with serum protein-functionalized SPR sensor surface have been determined via the van't Hoff analysis of the temperature-dependence of the equilibrium constant by using nonlinear fitting. In case of BSA the calculated parameters are $\Delta H^{o}=-1.94$ $\pm 0.25 \mathrm{~kJ} \mathrm{~mol}^{-1} ; \Delta S^{o}=0.025 \pm 0.0008 \mathrm{~J} \mathrm{~mol}^{-1} \mathrm{~K}^{-1}$ and $\Delta C_{p}=-2.17 \pm 0.18 \mathrm{~kJ} \mathrm{~mol}^{-1} \mathrm{~K}^{-1}$, while for HSA the following data were obtained: $\Delta H^{o}=-1.87 \pm 0.22 \mathrm{~kJ} \mathrm{~mol}^{-1} ; \Delta S^{o}=0.0255 \pm$ $0.0008 \mathrm{~J} \mathrm{~mol}^{-1} \mathrm{~K}^{-1}$ and $\Delta C_{p}=-2.95 \pm 0.09 \mathrm{~kJ} \mathrm{~mol}^{-1} \mathrm{~K}^{-1}$. It was found that, the reversible binding of KYNA is the result of an enthalpy- and entropy-controlled process. Comparing the thermodynamic parameters of the interaction between BSA/HSA and KYNA and the corresponding parameters of the AMPA receptor model fragments (GluR1 $1_{231-259}$ és GluR1270-300) it can be concluded that, for polypeptide fragments, the results of the SPRbased measurements confirm the presence of a more specific receptor-ligand type binding. 


\section{Köszönetnyilvánítás}

Ezúton szeretnék köszönetet mondani Prof. Dr. Dékány Imre akadémikusnak és Prof. Dr. Tóth Gábor intézetvezető egyetemi tanárnak, akik témavezetőként biztosították számomra, hogy a doktori értekezéshez kapcsolódó kutatásaimat az általuk vezetett kutatócsoportban végezhessem. Külön köszönettel tartozom Prof. Dr. Tóth Ágotának - az SZTE TTIK Fizikai Kémiai és Anyagtudományi Tanszék vezetőjének -, aki lehetővé tette számomra, hogy a disszertációmhoz szükséges kutatási tevékenységet az általa vezetett tanszéken végezhessem. Köszönet illeti Prof. Dr. Kiss Tamást és Prof. Dr. Gajda Tamást, akik bizalmukkal megtisztelve lehetővé tették, hogy az értekezésem elkészítésének időszakában az általuk irányított „Intelligens fémvegyületek” című projekt közreműködő kutatójaként dolgozhassak.

Szeretném megköszönni a támogatást és segítséget a Kutatócsoportunk valamennyi tagjának, Janóné Dr. Ungor Ditta Anitának, Marótiné Szokolai Hajnalkának, Dr. Varga Viktóriának, Turcsányi Árpádnak és Varga Norbertnek. Hálával tartozom Juhászné Dr. Csapó Editnek, aki kitartó, körültekintő és gondos vezetőként irányítja Kutatócsoportunk tudományos munkáját és mindennapjait.

Szeretném megköszönni mindazok szeretetét, gondoskodását és támogatását akik, egyetemi tanulmányaim és a dolgozat elkészítése során már nem lehettek mellettem.

Hálás és boldog vagyok, hogy megköszönhetem mindazt a szeretetet és segítséget, amit feleségemtől és lányomtól kaptam az elmúlt évek során, nélkülük biztosan sikertelenebb és boldogtalanabb lennék. Köszönöm, hogy mindig magam mellett tudhatom ezt a két csodálatos embert.

A kutatómunka dologi hátterét a GINOP-2.3.2-15-2016-00038 azonosító számmal rendelkezö „Intelligens fémvegyületek” pályázati projekt biztosította 2017-töl.

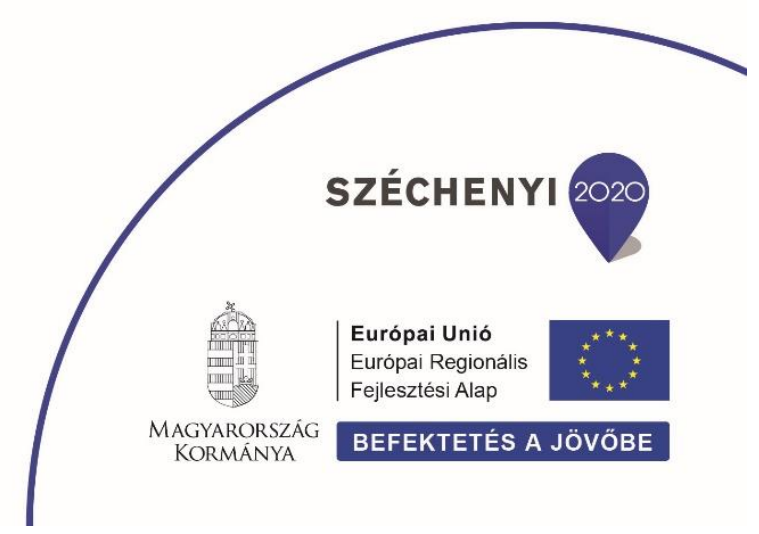




\section{Irodalomjegyzék}

[1] R.W. Wood, XLII. On a remarkable case of uneven distribution of light in a diffraction grating spectrum, Philos. Mag. Ser. 6.4 (1902) 396-402. doi:10.1080/14786440209462857.

[2] L. Rayleigh, On the Dynamical Theory of Gratings, Proc. R. Soc. A Math. Phys. Eng. Sci. 79 (1907) 399-416. doi:10.1098/rspa.1907.0051.

[3] E. Kretschmann, H. Raether, Radiative Decay of Non Radiative Surface Plasmons Excited by Light, 1968. http://zfn.mpdl.mpg.de/data/Reihe_A/23/ZNA-1968-23a2135_n.pdf (accessed January 3, 2019).

[4] A. Otto, Excitation of nonradiative surface plasma waves in silver by the method of frustrated total reflection, Zeitschrift Für Phys. A Hadron. Nucl. 216 (1968) 398-410. doi:10.1007/BF01391532.

[5] E. Petryayeva, U.J. Krull, Localized surface plasmon resonance: Nanostructures, bioassays and biosensing-A review, Anal. Chim. Acta. 706 (2011) 8-24. doi:10.1016/J.ACA.2011.08.020.

[6] N.W. Ashcroft, . Mermin, N. D, Solid State Physics, Holt, Rinehart and Winston, 1976. doi:10.1016/0038-1101(66)90069-4.

[7] S.R. (Stephen R. Elliott, The physics and chemistry of solids, J. Wiley, 1998.

[8] N. Kroó, S. Varró, P. Rácz, P. Dombi, Surface plasmons: a strong alliance of electrons and light, Phys. Scr. 91 (2016) 053010. doi:10.1088/0031-8949/91/5/053010.

[9] J. Homola, Surface plasmon resonance sensors for detection of chemical and biological species, Chem. Rev. 108 (2008) 462-493. doi:10.1021/cr068107d.

[10] A. Messica, A. Greenstein, A. Katzir, Theory of fiber-optic, evanescent-wave spectroscopy and sensors, Appl. Opt. 35 (1996) 2274. doi:10.1364/AO.35.002274.

[11] M. Bertolotti, Evanescent Waves in Optics An Introduction to Plasmonics, 1961. doi:10.1016/0022-2852(61)90347-2.

[12] W. Wang, M.J. Feldstein, N.F. Scherer, Observation of coherent multiple scattering of surface plasmon polaritons on Ag and Au surfaces, Chem. Phys. Lett. 262 (1996) 573-582. doi:10.1016/S0009-2614(96)01113-X.

[13] M. Milosevic, On the Nature of the Evanescent Wave, (n.d.). doi:10.1366/12-06707.

[14] S. Ekgasit, C. Thammacharoen, F. Yu, W. Knoll, Evanescent Field in Surface Plasmon Resonance and Surface Plasmon Field-Enhanced Fluorescence Spectroscopies, Anal. Chem. 76 (2004) 2210-2219. doi:10.1021/ac035326f. 
[15] J.R. Sambles, Optical excitation of surface plasmons, J. Phys. Chem. Solids. 50 (1989) 1-4. doi:10.1016/0022-3697(89)90464-2.

[16] J.R. Reitz, F.J. Milford, W.M. Schwarz, Foundations of Electromagnetic Theory, Pearson/Addison-Wesley, 1961. doi:10.1119/1.1937775.

[17] H. Raether, Surface plasmons on smooth surfaces, in: 1988: pp. 4-39. doi:10.1007/BFb0048319.

[18] M. Cardona, Fresnel Reflection and Surface Plasmons, Am. J. Phys. 39 (1971) 12771277. doi:10.1119/1.1976627.

[19] L. Novotny, B. Hecht, Principles of Nano-Optics, Cambridge University Press, Cambridge, 2006. doi:10.1017/CBO9780511813535.

[20] P.B. Johnson, R.W. Christy, Optical Constants of the Noble Metals, Phys. Rev. B. 6 (1972) 4370-4379. doi:10.1103/PhysRevB.6.4370.

[21] J. Zhang, L. Zhang, W. Xu, Surface plasmon polaritons: Physics and applications, J. Phys. D. Appl. Phys. 45 (2012) 113001. doi:10.1088/0022-3727/45/11/113001.

[22] K. Nagata, H. (Hiroshi) Handa, Real-time analysis of biomolecular interactions: applications of BIACORE, Springer, 2000.

[23] H. Liang, H. Miranto, N. Granqvist, J.W. Sadowski, T. Viitala, B. Wang, M. Yliperttula, Surface plasmon resonance instrument as a refractometer for liquids and ultrathin films, Sensors Actuators B Chem. 149 (2010) 212-220. doi:10.1016/J.SNB.2010.05.048.

[24] L. Ji, Y. Chen, Y.J. Yuan, Investigation of surface plasmon resonance phenomena by finite element analysis and Fresnel calculation, Sensors Actuators B Chem. 198 (2014) 82-86. doi:10.1016/J.SNB.2014.02.105.

[25] H. Baccar, M.B. Mejri, I. Hafaiedh, T. Ktari, M. Aouni, A. Abdelghani, Surface plasmon resonance immunosensor for bacteria detection, Talanta. 82 (2010) 810-814. doi:10.1016/J.TALANTA.2010.05.060.

[26] R.J. Sengwa, S. Sankhla, S. Sharma, Refractometric study of polymers and their blends in solution, Indian J. Chem. - Sect. A Inorganic, Phys. Theor. Anal. Chem. 46 (2007)1419-1422.

[27] C. Nylander, B. Liedberg, T. Lind, Gas detection by means of surface plasmon resonance, Sensors and Actuators. 3 (1982) 79-88. doi:10.1016/02506874(82)80008-5.

[28] B. Liedberg, C. Nylander, I. Lunström, Surface plasmon resonance for gas detection and biosensing, Sensors and Actuators. 4 (1983) 299-304. doi:10.1016/0250- 
6874(83)85036-7.

[29] I. Pockrand, J.D. Swalen, J.G. Gordon, M.R. Philpott, Surface plasmon spectroscopy of organic monolayer assemblies, Surf. Sci. 74 (1978) 237-244. doi:10.1016/00396028(78)90283-2.

[30] K.A. Peterlinz, R. Georgiadis, Two-color approach for determination of thickness and dielectric constant of thin films using surface plasmon resonance spectroscopy, Opt. Commun. 130 (1996) 260-266. doi:10.1016/0030-4018(96)00238-6.

[31] C. Striebel, A. Brecht, G. Gauglitz, Characterization of biomembranes by spectral ellipsometry, surface plasmon resonance and interferometry with regard to biosensor application., Biosens. Bioelectron. 9 (1994) 139-46.

[32] M. Malmqvist, Biospecific interaction analysis using biosensor technology, Nature. 361 (1993) 186-187. doi:10.1038/361186a0.

[33] D.C. Cullen, R.G.W. Brown, C.R. Lowe, Detection of immuno-complex formation via surface plasmon resonance on gold-coated diffraction gratings, Biosensors. 3 (1987) 211-225. doi:10.1016/0265-928X(87)85002-2.

[34] G. Dahl, S. Steigele, P. Hillertz, A. Tigerström, A. Egnéus, A. Mehrle, M. Ginkel, F. Edfeldt, G. Holdgate, N. O’Connell, B. Kappler, A. Brodte, P.B. Rawlins, G. Davies, E.L. Westberg, R.H.A. Folmer, S. Heyse, Unified software solution for efficient SPR data analysis in drug research, SLAS Discov. 22 (2017) 203-209. doi:10.1177/1087057116675316.

[35] S. Löfås, M. Malmqvist, I. Rönnberg, E. Stenberg, B. Liedberg, I. Lundström, Bioanalysis with surface plasmon resonance, Sensors Actuators B Chem. 5 (1991) 79-84. doi:10.1016/0925-4005(91)80224-8.

[36] M. Malmqvist, Surface plasmon resonance for detection and measurement of antibody-antigen affinity and kinetics, Curr. Opin. Immunol. 5 (1993) 282-286. doi:10.1016/0952-7915(93)90019-O.

[37] M. Malmqvist, Kinetic analysis of engineered antibody-antigen interactions, J. Mol. Recognit. 7 (1994) 1-7. doi:10.1002/jmr.300070102.

[38] S. Löfås, B. Johnsson, A novel hydrogel matrix on gold surfaces in surface plasmon resonance sensors for fast and efficient covalent immobilization of ligands, J. Chem. Soc., Chem. Commun. 0 (1990) 1526-1528. doi:10.1039/C39900001526.

[39] J. Bergstrom, S. Lofas, B. Johnsson, Sensing surfaces capable of selective biomolecular interactions, to be used in biosensor systems, US Pat. 5,242,828. (1993).

[40] A.S.S. Lof, I. Ronnberg, K. Lagerstrom, Solid phase binding assay, (1998). 
http://www.freepatentsonline.com/5716854.html (accessed January 29, 2019).

[41] S. Mariani, M. Minunni, Surface plasmon resonance applications in clinical analysis, Anal. Bioanal. Chem. 406 (2014) 2303-2323. doi:10.1007/s00216-014-7647-5.

[42] M.L. Jeong, K.P. Hyun, Y. Jung, K.K. Jin, O.J. Sun, H.C. Bong, Direct immobilization of protein $\mathrm{G}$ variants with various numbers of cysteine residues on a gold surface, Anal. Chem. 79 (2007) 2680-2687. doi:10.1021/ac0619231.

[43] U. Schlecht, Y. Nomura, T. Bachmann, I. Karube, Reversible surface thiol immobilization of carboxyl group containing haptens to a BIAcore biosensor chip enabling repeated usage of a single sensor surface, Bioconjug. Chem. 13 (2002) 188193. doi:10.1021/bc0100399.

[44] T.M. Davis, W.D. Wilson, Determination of the Refractive Index Increments of Small Molecules for Correction of Surface Plasmon Resonance Data, Anal. Biochem. 284 (2000) 348-353. doi:10.1006/abio.2000.4726.

[45] T.M. Davis, W.D. Wilson, Surface plasmon resonance biosensor analysis of RNAsmall molecule interactions., Methods Enzymol. 340 (2001) 22-51. http://www.ncbi.nlm.nih.gov/pubmed/11494851 (accessed January 30, 2019).

[46] B. Nguyen, F.A. Tanious, W.D. Wilson, Biosensor-surface plasmon resonance: Quantitative analysis of small molecule-nucleic acid interactions, Methods. 42 (2007) 150-161. doi:10.1016/j.ymeth.2006.09.009.

[47] D.G. Myszka, Kinetic analysis of macromolecular interactions using surface plasmon resonance biosensors, Curr. Opin. Biotechnol. 8 (1997) 50-57. doi:10.1016/S09581669(97)80157-7.

[48] D.G. Myszka, X. He, M. Dembo, T.A. Morton, B. Goldstein, Extending the range of rate constants available from BIACORE: Interpreting mass transport-influenced binding data, Biophys. J. 75 (1998) 583-594. doi:10.1016/S0006-3495(98)77549-6.

[49] D.G. Myszka, T.A. Morton, Clamp: A biosensor kinetic data analysis program, Trends Biochem. Sci. 23 (1998) 149-150. doi:10.1016/S0968-0004(98)01183-9.

[50] B. Liedberg, C. Nylander, I. Lundström, Biosensing with surface plasmon resonance - how it all started, Biosens. Bioelectron. 10 (1995) i-ix. doi:10.1016/09565663(95)96965-2.

[51] H. Wolf, The effect of hormones and vitamin B6 on urinary excretion of metabolites of the kynurenine pathway., Scand. J. Clin. Lab. Invest. Suppl. 136 (1974) 1-186. http://www.ncbi.nlm.nih.gov/pubmed/4275489 (accessed January 31, 2019).

[52] L. Vécsei, L. Szalárdy, F. Fülöp, J. Toldi, Kynurenines in the CNS: recent advances 
and new questions, Nat. Rev. Drug Discov. 12 (2013) 64-82. doi:10.1038/nrd3793.

[53] M.N. Perkins, T.W. Stone, An iontophoretic investigation of the actions of convulsant kynurenines and their interaction with the endogenous excitant quinolinic acid., Brain Res. 247 (1982) 184-7. http://www.ncbi.nlm.nih.gov/pubmed/6215086 (accessed January 31, 2019).

[54] C. Hilmas, E.F. Pereira, M. Alkondon, A. Rassoulpour, R. Schwarcz, E.X. Albuquerque, The brain metabolite kynurenic acid inhibits alpha7 nicotinic receptor activity and increases non-alpha7 nicotinic receptor expression: physiopathological implications., J. Neurosci. 21 (2001) 7463-73.

[55] C. Prescott, A.M. Weeks, K.J. Staley, K.M. Partin, Kynurenic acid has a dual action on AMPA receptor responses, Neurosci. Lett. 402 (2006) 108-112. doi:10.1016/j.neulet.2006.03.051.

[56] D. Sebők, E. Csapó, T. Preočanin, G. Bohus, N. Kallay, I. Dékány, Adsorption of Ibuprofen and Dopamine on Functionalized Gold Using Surface Plasmon Resonance Spectroscopy at Solid-Liquid Interface, Croat. Chem. Acta. 86 (2013) 287-295. doi:10.5562/cca2343.

[57] S. Sircar, R. Mohr, C. Ristic, M.B. Rao, Isosteric Heat of Adsorption: Theory and Experiment, J. Phys. Chem. B. 103 (1999) 6539-6546. doi:10.1021/jp9903817.

[58] E. Csapó, Z. Majláth, Á. Juhász, B. Roósz, A. Hetényi, G.K. Tóth, J. Tajti, L. Vécsei, I. Dékány, Determination of binding capacity and adsorption enthalpy between Human Glutamate Receptor (GluR1) peptide fragments and kynurenic acid by surface plasmon resonance experiments, Colloids Surfaces B Biointerfaces. 123 (2014) 924929. doi:10.1016/J.COLSURFB.2014.10.046.

[59] T. Hayashi, G. Rumbaugh, R.L. Huganir, Differential Regulation of AMPA Receptor Subunit Trafficking by Palmitoylation of Two Distinct Sites, Neuron. 47 (2005) 709723. doi:10.1016/J.NEURON.2005.06.035.

[60] A.I. Sobolevsky, M.P. Rosconi, E. Gouaux, X-ray structure, symmetry and mechanism of an AMPA-subtype glutamate receptor., Nature. 462 (2009) 745-56. doi:10.1038/nature08624.

[61] L. Ligands'juan, S. Gomez-Jeria, L. Lagos-Arancibia, Quantum-Chemical StructureAffinity Studies on Kynurenic Acid Derivatives as Gly / NMDA Receptor Ligands'JUAN, John Wiley \& Sons, Inc, 1999.

[62] S. Wu, Y. Zhang, LOMETS: A local meta-threading-server for protein structure prediction, Nucleic Acids Res. 35 (2007) 3375-3382. doi:10.1093/nar/gkm251. 
[63] R. Slavík, J. Homola, Ultrahigh resolution long range surface plasmon-based sensor, Sensors Actuators B Chem. 123 (2007) 10-12. doi:10.1016/J.SNB.2006.08.020.

[64] B. Liedberg, I. Lundström, E. Stenberg, Principles of biosensing with an extended coupling matrix and surface plasmon resonance, Sensors Actuators B. Chem. 11 (1993) 63-72. doi:10.1016/0925-4005(93)85239-7.

[65] B. Söptei, J. Mihály, I.C. Szigyártó, A. Wacha, C. Németh, I. Bertóti, Z. May, P. Baranyai, I.E. Sajó, A. Bóta, The supramolecular chemistry of gold and 1-cysteine: Formation of photoluminescent, orange-emitting assemblies with multilayer structure, Colloids Surfaces A Physicochem. Eng. Asp. 470 (2015) 8-14. doi:10.1016/J.COLSURFA.2015.01.048.

[66] C. Lavenn, L. Okhrimenko, N. Guillou, M. Monge, G. Ledoux, C. Dujardin, R. Chiriac, A. Fateeva, A. Demessence, A luminescent double helical gold( i )thiophenolate coordination polymer obtained by hydrothermal synthesis or by thermal solid-state amorphous-to-crystalline isomerization, J. Mater. Chem. C. 3 (2015) 4115-4125. doi:10.1039/C5TC00119F.

[67] H. Nie, M. Li, Y. Hao, X. Wang, S.X.-A. Zhang, Time-resolved monitoring of dynamic self-assembly of Au(i)-thiolate coordination polymers, Chem. Sci. 4 (2013) 1852. doi:10.1039/c3sc22215b.

[68] E. Csapó, D. Ungor, Á. Juhász, G.K. Tóth, I. Dékány, Gold nanohybrid systems with tunable fluorescent feature: Interaction of cysteine and cysteine-containing peptides with gold in two- and three-dimensional systems, Colloids Surfaces A Physicochem. Eng. Asp. 511 (2016) 264-271. doi:10.1016/J.COLSURFA.2016.10.003.

[69] C.S. Lu, O. Lewis, Investigation of film-thickness determination by oscillating quartz resonators with large mass load, J. Appl. Phys. 43 (1972) 4385-4390. doi:10.1063/1.1660931.

[70] Y. Kusakawa, E. Yoshida, T. Hayakawa, Protein Adsorption to Titanium and Zirconia Using a Quartz Crystal Microbalance Method., Biomed Res. Int. 2017 (2017) 1521593. doi:10.1155/2017/1521593.

[71] B.A. Russell, B. Jachimska, P. Komorek, P.A. Mulheran, Y. Chen, Lysozyme encapsulated gold nanoclusters: effects of cluster synthesis on natural protein characteristics, Phys. Chem. Chem. Phys. 19 (2017) 7228-7235. doi:10.1039/C7CP00540G.

[72] N. Varga, E. Csapó, Z. Majláth, I. Ilisz, I.A. Krizbai, I. Wilhelm, L. Knapp, J. Toldi, L. Vécsei, I. Dékány, Targeting of the kynurenic acid across the blood-brain barrier 
by core-shell nanoparticles, Eur. J. Pharm. Sci. 86 (2016) 67-74. doi:10.1016/J.EJPS.2016.02.012.

[73] N. Varga, V. Hornok, L. Janovák, I. Dékány, E. Csapó, The effect of synthesis conditions and tunable hydrophilicity on the drug encapsulation capability of PLA and PLGA nanoparticles, Colloids Surfaces B Biointerfaces. 176 (2019) 212-218. doi:10.1016/J.COLSURFB.2019.01.012.

[74] Á. Deák, E. Csapó, Á. Juhász, I. Dékány, L. Janovák, Anti-ulcerant kynurenic acid molecules intercalated $\mathrm{Mg} / \mathrm{Al}$-layered double hydroxide and its release study, Appl. Clay Sci. 156 (2018) 28-35. doi:10.1016/J.CLAY.2018.01.024.

[75] E. Csapó, H. Szokolai, Á. Juhász, N. Varga, L. Janovák, I. Dékány, Cross-linked and hydrophobized hyaluronic acid-based controlled drug release systems, Carbohydr. Polym. 195 (2018) 99-106. doi:10.1016/J.CARBPOL.2018.04.073.

[76] Á. Deák, L. Janovák, E. Csapó, D. Ungor, I. Pálinkó, S. Puskás, T. Ördög, T. Ricza, I. Dékány, Layered double oxide (LDO) particle containing photoreactive hybrid layers with tunable superhydrophobic and photocatalytic properties, Appl. Surf. Sci. 389 (2016) 294-302. doi:10.1016/J.APSUSC.2016.07.127.

[77] N. Varga, M. Benkő, D. Sebők, I. Dékány, BSA/polyelectrolyte core-shell nanoparticles for controlled release of encapsulated ibuprofen, Colloids Surfaces B Biointerfaces. 123 (2014) 616-622. doi:10.1016/J.COLSURFB.2014.10.005.

[78] J.J. Boniface, M.M. Davis, The Kinetics of Binding of Peptide/MHC Complexes to T-Cell Receptors: Application of Surface Plasmon Resonance to a Low-Affinity Measurement, Methods. 6 (1994) 168-176. doi:10.1006/METH.1994.1019.

[79] R. Karlsson, A. Michaelsson, L. Mattsson, Kinetic analysis of monoclonal antibodyantigen interactions with a new biosensor based analytical system, J. Immunol. Methods. 145 (1991) 229-240. doi:10.1016/0022-1759(91)90331-9.

[80] Y.-Y. Yu, B.J. Van Wie, A.R. Koch, D.F. Moffett, W.C. Davis, Real-Time Analysis of Immunogen Complex Reaction Kinetics Using Surface Plasmon Resonance, Anal. Biochem. 263 (1998) 158-168. doi:10.1006/ABIO.1998.2784.

[81] D.C. Harris, Nonlinear Least-Squares Curve Fitting with Microsoft Excel Solver, J. Chem. Educ. 75 (1998) 119. doi:10.1021/ed075p119.

[82] G. Yao, Y. Zong, S. Gu, J. Zhou, H. Xu, I.I. Mathews, R. Jin, Crystal structure of the glutamate receptor GluA1 N-terminal domain., Biochem. J. 438 (2011) 255-63. doi:10.1042/BJ20110801.

[83] B. Hess, C. Kutzner, D. van der Spoel, E. Lindahl, GROMACS 4: Algorithms for 
Highly Efficient, Load-Balanced, and Scalable Molecular Simulation, J. Chem. Theory Comput. 4 (2008) 435-447. doi:10.1021/ct700301q.

[84] F. Iori, R. Di Felice, E. Molinari, S. Corni, GolP: An atomistic force-field to describe the interaction of proteins with $\mathrm{Au}(111)$ surfaces in water, J. Comput. Chem. 30 (2009) 1465-1476. doi:10.1002/jcc.21165.

[85] X. Li, S.M. Husson, Adsorption of dansylated amino acids on molecularly imprinted surfaces: A surface plasmon resonance study, Biosens. Bioelectron. 22 (2006) 336348. doi:10.1016/J.BIOS.2006.04.016.

[86] E. Csapó, Z. Majláth, T. Juhász, B. Roósz, A. Hetényi, G.K. Tóth, J. Tajti, L. Vécsei, I. Dékány, Determination of binding capacity and adsorption enthalpy between Human Glutamate Receptor (GluR1) peptide fragments and kynurenic acid by surface plasmon resonance experiments, Colloids Surfaces B Biointerfaces. 123 (2014) 924929. doi:10.1016/j.colsurfb.2014.10.046.

[87] E. Csapó, Z. Majláth, T. Juhász, B. Roósz, A. Hetényi, G.K. Tóth, J. Tajti, L. Vécsei, I. Dékány, Determination of binding capacity and adsorption enthalpy between Human Glutamate Receptor (GluR1) peptide fragments and kynurenic acid by surface plasmon resonance experiments, Colloids Surfaces B Biointerfaces. 123 (2014) 924929. doi:10.1016/j.colsurfb.2014.10.046.

[88] M.L. Johnson, Why, when, and how biochemists should use least squares, Anal. Biochem. 206 (1992) 215-225. doi:10.1016/0003-2697(92)90356-C.

[89] G.N. WILKINSON, Statistical estimations in enzyme kinetics., Biochem. J. 80 (1961) 324-32. http://www.ncbi.nlm.nih.gov/pubmed/13785321 (accessed March 27, 2019).

[90] R. Eisenthal, A. Cornish-Bowden, The direct linear plot. A new graphical procedure for estimating enzyme kinetic parameters, Biochem. J. 139 (1974) 715. https://www.ncbi.nlm.nih.gov/pmc/articles/PMC1166335/ (accessed March 27, 2019).

[91] D.J. Oshannessy, M. Brighamburke, K.K. Soneson, P. Hensley, I. Brooks, Determination of Rate and Equilibrium Binding Constants for Macromolecular Interactions Using Surface Plasmon Resonance: Use of Nonlinear Least Squares Analysis Methods, Anal. Biochem. 212 (1993) 457-468. doi:10.1006/ABIO.1993.1355.

[92] Á. Juhász, R. Tabajdi, I. Dékány, E. Csapó, Thermodynamic Characterization of Temperature- and Composition-Dependent Mixed Micelle Formation in Aqueous Medium, J. Surfactants Deterg. 20 (2017) 1291-1299. doi:10.1007/s11743-017- 
2025-x.

[93] D. Ungor, E. Csapó, B. Kismárton, Á. Juhász, I. Dékány, Nucleotide-directed syntheses of gold nanohybrid systems with structure-dependent optical features: Selective fluorescence sensing of Fe3+ ions, Colloids Surfaces B Biointerfaces. 155 (2017) 135-141. doi:10.1016/J.COLSURFB.2017.04.013.

[94] V. Plis'ka, Thermodynamic Parameters of Ligand-Receptor Interactions: Computation and Error Margins, J. Recept. Signal Transduct. 17 (1997) 495-510. doi:10.3109/10799899709036623.

[95] A. Cooper, Thermodynamic analysis of biomolecular interactions., Curr. Opin. Chem. Biol. 3 (1999) 557-63. http://www.ncbi.nlm.nih.gov/pubmed/10508661 (accessed December 4, 2016).

[96] G.A. Holdgate, W.H.J. Ward, Measurements of binding thermodynamics in drug discovery, Drug Discov. Today. 10 (2005) 1543-1550. doi:10.1016/S13596446(05)03610-X.

[97] P.D. Ross, S. Subramanian, Thermodynamics of protein association reactions: forces contributing to stability, Biochemistry. $20 \quad$ (1981) 3096-3102. doi:10.1021/bi00514a017.

[98] M.S. Caceci, Estimating error limits in parametric curve fitting, Anal. Chem. 61 (1989) 2324-2327. doi:10.1021/ac00195a023.

[99] P.D. Ross, S. Subramanian, Thermodynamics of Protein Association Reactions: Forces Contributing to Stability, Biochemistry. 20 (1981) 3096-3102. doi:10.1021/bi00514a017.

[100] Z. Tian, F. Zang, W. Luo, Z. Zhao, Y. Wang, X. Xu, C. Wang, Spectroscopic study on the interaction between mononaphthalimide spermidine (MINS) and bovine serum albumin (BSA), J. Photochem. Photobiol. B Biol. 142 (2015) 103-109. doi:10.1016/j.jphotobiol.2014.10.013.

[101] L. Aberkane, J. Jasniewski, C. Gaiani, J. Scher, C. Sanchez, Thermodynamic Characterization of Acacia Gum- $\beta$-Lactoglobulin Complex Coacervation, Langmuir. 26 (2010) 12523-12533. doi:10.1021/la100705d.

[102] D. Sahal, P. Balaram, Peptide models of electrostatic interactions in proteins: NMR studies on two .beta.-turn tetrapeptides containing Asp-His and Asp-Lys salt bridges, Biochemistry. 25 (1986) 6004-6013. doi:10.1021/bi00368a026.

[103] H.R. Bosshard, D.N. Marti, I. Jelesarov, Protein stabilization by salt bridges: concepts, experimental approaches and clarification of some misunderstandings, J. 
Mol. Recognit. 17 (2004) 1-16. doi:10.1002/jmr.657.

[104] T.-C. Kuo, P.-C. Lee, C.-W. Tsai, W.-Y. Chen, Salt bridge exchange binding mechanism between streptavidin and its DNA aptamer - thermodynamics and spectroscopic evidences, J. Mol. Recognit. 26 (2013) 149-159. doi:10.1002/jmr.2260.

[105] M. Shiroishi, A. Yokota, K. Tsumoto, H. Kondo, Y. Nishimiya, K. Horii, M. Matsushima, K. Ogasahara, K. Yutani, I. Kumagai, Structural evidence for entropic contribution of salt bridge formation to a protein antigen-antibody interaction: the case of hen lysozyme-HyHEL-10 Fv complex., J. Biol. Chem. 276 (2001) 23042-50. doi:10.1074/jbc.M100480200. 


\section{Publikációs jegyzék}

Magyar Tudományos Müvek Tára (MTMT) azonosító: 10045092

\section{Az értekezés témájához közvetlen kapcsolódó publikációk:}

1. Á. Juhász, M. Luty-Błocho, M Wojnicki, G. K. Tóth, E. Csapó, A general method for kinetic and thermodynamic evaluation of a receptor model peptide-drug molecule interaction studied by surface plasmon resonance

Microchemical Journal, 147, 311-318. (2019) $(\mathrm{IF}=2,746)$

2. Á. Juhász, E. Csapó, L. Vécsei, I. Dékány, Modelling and Characterization of the Sorption of Kynurenic Acid on Protein Surfaces

Periodica Polytechnica Chemical Engineering, 61 (1), 3-9. (2017) $(\mathrm{IF}=0,557)$

3. Á Juhász, E. Csapó, D. Ungor, G.K. Tóth, L. Vécsei, I. Dékány, Kinetic and Thermodynamic Evaluation of Kynurenic Acid Binding to GluR1270-300 Polypeptide by Surface Plasmon Resonance Experiments

The Journal of Physical Chemistry B, 120(32), 7844-7850. (2016) $(\mathrm{IF}=3,117)$

4. E. Csapó, Á. Juhász, N. Varga, D. Sebők, V. Hornok, L. Janovák, I Dékány, Thermodynamic and kinetic characterization of $\mathrm{pH}$-dependent interactions between bovine serum albumin and ibuprofen in 2D and 3D systems

Colloids and Surfaces A, 504, 471-478. (2016) $(\mathrm{IF}=2,714)$

5. E. Csapó, F. Bogár, Á. Juhász, D. Sebők, J. Szolomájer, G.K. Tóth, Z. Majláth, L. Vécsei, I. Dékány, Determination of binding capacity and adsorption enthalpy between Human Glutamate Receptor (GluR1) peptide fragments and kynurenic acid by surface plasmon resonance experiments. Part 2: Interaction of GluR1 270-300 with KYNA

Colloids and Surfaces B, 133, 66-72. (2015) $(\mathrm{IF}=3,902)$

Összesített impakt: 13,036

\section{Az értekezés témájához közvetlen nem kapcsolódó publikációk:}

1. Csapó Edit, Sebők Dániel, Janovák László, Juhász Ádám, Dékány Imre, Nanoszerkezetű anyagok alkalmazása a szenzor fejlesztés, az olajipar, a gyógyszerkutatás és a heterogén katalízis területén

Magyar Kémiai Folyóirat, 125. évfolyam, 1. szám (2019)

2. L. Janovák, Á. Turcsányi, É. Bozó, Á. Deák, L. Mérai, D. Sebők, Á. Juhász, E. Csapó, M. M. Abdelghafour, E. Farkas, I. Dékány, F. Bari, Preparation of novel tissue acidosisresponsive chitosan drug nanoparticles: characterization and in vitro release properties of $\mathrm{Ca}^{2+}$ channel blocker nimodipine drug molecules

European Journal of Pharmaceutical Sciences, 123, 79-88. (2018) $(\mathrm{IF}=3,466)$ 
3. E. Csapó, H. Szokolai, Á. Juhász, N. Varga, L. Janovák, I. Dékány, Cross-linked and hydrophobized hyaluronic acid-based controlled drug release systems

Carbohydrate Polymers, 195, 99-106. (2018) $(\mathrm{IF}=5,158)$

4. Á. Deák, E. Csapó, Á. Juhász, I. Dékány, L. Janovák, Anti- ulcerant kynurenic acid molecules intercalated $\mathrm{Mg} / \mathrm{Al}$-layered double hydroxide and its release study Applied Clay Science, 156, 28-35. (2018) (IF= 3,641)

5. Á. Juhász, R. Tabajdi, E. Csapó, I. Dékány, Thermodynamic characterization of temperature- and composition dependent mixed micelle formation in aqueous medium, Journal of Surfactants and Detergents, 20(6), 1291-1299. (2017) $(\mathrm{IF}=1,450)$

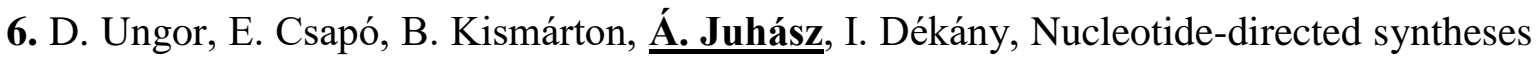
of gold nanohybrid systems with structure-dependent optical features: Selective fluorescence sensing of $\mathrm{Fe}^{3+}$ ions

Colloids and Surfaces B, 155, 135-141. (2017) $(\mathrm{IF}=3,997)$

7. E. Csapó, D. Ungor, Z. Kele, P. Baranyai, A. Deák, Á. Juhász, L. Janovák, I. Dékány, Influence of $\mathrm{pH}$ and aurate/amino acid ratios on the tuneable optical features of gold nanoparticles and nanoclusters

Colloids and Surfaces A, 532, 601-608. (2017) (IF=2,829)

8. E. Csapó, D. Ungor, Á. Juhász, G.K. Tóth, I. Dékány, Gold nanohybrid systems with tunable fluorescent feature: Interaction of cysteine and cysteine-containing peptides with gold in two-and three-dimensional systems

Colloids and Surfaces A, 511, 264-271. (2016) $(\mathrm{IF}=2,714)$

9. S.P Tallósy, L. Janovák, E. Nagy, Á. Deák, Á Juhász, E. Csapó, N. Buzás, I. Dékány, Adhesion and inactivation of Gram-negative and Gram-positive bacteria on photoreactive TiO 2/polymer and Ag-TiO 2/polymer nanohybrid films

Applied Surface Science, 371, 139-150. (2016) $(\mathrm{IF}=3,387)$

10. M. Benkő, N. Varga, D. Sebők, G. Bohus, Á. Juhász, I. Dékány, Bovine serum albuminsodium alkyl sulfates bioconjugates as drug delivery systems

Colloids and Surfaces B, 130, 126-132. (2015) $(\mathrm{IF}=3,902)$

11. E. Csapó, Z. Majláth, Á. Juhász, B. Roósz, A. Hetényi, G.K. Tóth, J. Tajti, L. Vécsei, I. Dékány, Determination of binding capacity and adsorption enthalpy between Human Glutamate Receptor (GluR1) peptide fragments and kynurenic acid by surface plasmon resonance experiments

Colloids and Surfaces B, 123, 924-929. (2014) $(\mathrm{IF}=4,145)$ 
12. S.P. Tallósy, L. Janovák, J. Ménesi, E. Nagy, Á Juhász, I. Dékány, LED-light Activated Antibacterial Surfaces Using Silver-modified TiO2 Embedded in Polymer Matrix Journal of Advanced Oxidation Technologies, 17(1), 9-16. (2014) $(\mathrm{IF}=1,106)$

13. Á. Veres, J. Ménesi, Á. Juhász, O. Berkesi, N. Ábrahám, G. Bohus, A. Oszkó, G. Pótári, N. Buzás, L. Janovák, I. Dékány, Photocatalytic performance of silver-modified TiO2 embedded in poly (ethyl-acrylate-co-methyl metacrylate) matrix

Colloid and Polymer Science, 292(1), 207-217. (2014) (IF=2,410)

14. S.P. Tallósy, L. Janovák, J. Ménesi, E. Nagy, Á Juhász, L. Balázs, I. Deme, N. Buzás, I. Dékány, Investigation of the antibacterial effects of silver-modified $\mathrm{TiO} 2$ and $\mathrm{ZnO}$ plasmonic photocatalysts embedded in polymer thin films

Environmental Science and Pollution Research, 21(19), 11155-11167. (2014) $(\mathrm{IF}=2,828)$

15. E. Csapó, A. Oszkó, E. Varga, Á. Juhász, N. Buzás, L. Körösi, A. Majzik, I. Dékány, Synthesis and characterization of $\mathrm{Ag} / \mathrm{Au}$ alloy and core (Ag)-shell (Au) nanoparticles Colloids and Surfaces A, 415, 281-287. (2012) (IF= 2,236)

Összesített impakt: 43,269

\section{A publikációk összesített impakt faktora: $\mathbf{5 6 , 3 0 5}$}

\section{Az értekezés témájában nemzetközi és hazai konferenciákon bemutatott előadások:}

1. Juhász Ádám, A kinurénsav kötődésének felületi plazmon rezonancia spektroszkópiás vizsgálata receptor modelleken

DOSZ Tavaszi Szél konferencia, 2018. máj. 4-5, Győr, Magyarország

2. Juhász Ádám: Makromolekulák és ligandumaik önszerveződésének felületi plazmon rezonancia spektroszkópiás kinetikai és termodinamikai jellemzése

MTA Kolloidkémai Munkabizottság 26. ülése, 2017. október 26, Budapest, Magyarország

3. Juhász Ádám, Felületi plazmon rezonancia spektroszkópia alkalmazása receptor ligandum kölcsönhatások modellezésében

MTA Kolloidkémai Munkabizottság 25. ülése, 2017. június 1-2, Velence, Magyarország

4. Dékány, N. Varga, E. Csapó, V. Hornok, D. Ungor, Á. Juhász, D. Sebők, Self-assembled core-shell nanoparticles for drug delivery: structural properties and kinetic of the release process

$6^{\text {th }}$ International Congress, Nanotechnology in Medicine and Biology, BioNanoMed-2015, 8-10 April, 2015, Graz, Austria

5. N. Varga, E. Csapó, D. Sebők, Á. Juhász, L. Janovák, I. Dékány, Syntheses and characterization of potential drug carrier nanocomposites

$11^{\text {th }}$ Int. Conf. on Diffusion in Solids and Liquids, 22-25 June, 2015, München, Germany 
6. Dékány, E. Csapó, Á. Juhász, D. Sebők, V. Hornok, Protein-drug molecule interactions characterized by thermodynamic state functions using 2D and 3D experiments

European Colloid and Interface Society (ECIS) COST CM 1101, 6-11 September, 2015, Bordeaux, France

\section{Az értekezés témájában nemzetközi konferenciákon bemutatott poszter prezentációk:}

1. Á. Juhász, E. Csapó, D. Ungor, Surface plasmon resonance sensor based characterization of the binding process of bioactive metal complexes with endogen bioligands

ICONAN2018, 26-28 September, 2018, Rome, Italy

2. Á. Juhász, E. Csapó, G. K. Tóth, I. Dékány, Binding of drugs and metal complexes onto biomimetic interfaces

$31^{\text {th }}$ European Colloid and Interface Society (ECIS-31), 3-8 September, 2017, Madrid, Spain

3. Á. Juhász, E. Csapó, H. Szokolai, D. Ungor, I. Dékány, Modelling and characterization of drug binding to peptide functionalized gold surfaces

$7^{\text {th }}$ International Colloids Conference, 17-21 June, 2017, Barcelona-Sitges, Spain

4. D. Ungor, E. Csapó, Á. Juhász, I. Dékány, Interaction of cysteine and cysteine-containing peptides with gold in two- and three-dimensional systems

$7^{\text {th }}$ International Colloids Conference, 17-21 June, 2017, Barcelona-Sitges, Spain

5. Á. Juhász, E. Csapó, H. Szokolai, D. Ungor, I. Dékány, Kinetics and thermodynamics characterization of the interactions between kynurenic acid and human glutamate receptor fragments by surface plasmon resonance studies

$30^{\text {th }}$ European Colloid and Interface Society (ECIS-30), 4-9 September, 2016, Rome, Italy

6. E. Csapó, F. Bogár, Á. Juhász, D. Sebők, L. Vécsei, G.K Tóth, I. Dékány, Interaction between GluR $1_{201-300}$ peptide fragments of AMPA receptor and kynurenic acid: SPR experiments and molecular modelling

$6^{\text {th }}$ International Congress, Nanotechnology in Medicine and Biology, BioNanoMed-2015, 8-10 April, 2015, Graz, Austria

\section{Oltalmi formák:}

1. A. Majzik, I. Dékány, T. Bartók, N. Buzás, Á. Juhász, D. Sebők, J. Ménesi, E. Csapó, B. Roósz

Eljárás Aflatoxin B1 vegyület kimutatására plazmonikus arany nanofilmek és részecskék felületén, Benyújtás éve (szabadalom): 2013, Benyújtás száma: P1300545, Benyújtás országa: Magyarország

2. I. Dékány, N. Buzás, L. Janovák, Á. Juhász, Sz. Tallósi

Eljárás antibakteriális festékrétegek felvitelére különböző falfelületeken

P1200745, Benyújtás éve (szabadalom): 2012 


\section{I. Deme, M. Budai, I. Dékány, Á. Juhász}

Increased weight of emission materials on fluorescent lamp electrodes US20130169150, Benyújtás éve (szabadalom): 2011, Benyújtás száma: 13/339,419, Ügyszám: WO2013101396 A1, Benyújtás országa: Amerikai Egyesült Államok

\section{Az értekezés témájához közvetlen nem kapcsolódó előadások:}

1. Ádám Juhász, Relation between rheological, structural and dissolution properties of covalently and ionically modified hyaluronic acid-based drug carriers NANOCON2018, 17-19 October, 2018, Brno, Czech Republic

2. E. Csapó, D. Ungor, Á. Juhász, Selective detection of ions and small molecules using fluorescent gold nanoclusters in aqueous medium

ICONAN2018, 26-28 September, 2018, Rome, Italy

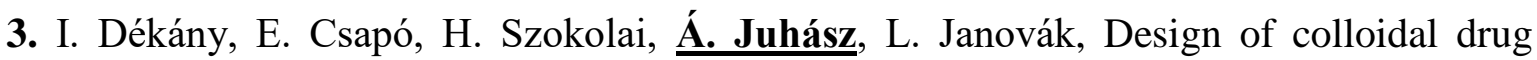
delivery composites for controlled release of non-steroidal anti-inflammatory drugs 6th World Conference on Physico Chemical Methods in Drug Discovery and Development (PCMDDD-6), 4-7 September, 2017, Zagreb, Croatia

4. E. Csapó, D. Ungor, Á. Juhász, B. Kismárton, I. Dékány: Biocompatible gold nanohybrid structures with tuneable plasmonic or fluorescent features: syntheses, structural characterization, possible sensor and biolabelling applications

World Summit on Nanotechnology and Nanomedicine Research (Nanomed-2016), 28-29 ${ }^{\text {th }}$ November, Dubai, UAE.

5. E. Csapó, D. Ungor, Á. Juhász, B. Kismárton, I. Dékány, Ultra-small gold nanoclusters with tuneable fluorescent features: syntheses, structural identification and sensoric applications

$30^{\text {th }}$ European Colloid and Interface Society (ECIS-30), 4-9 September, 2016, Rome, Italy

6. E. Csapó, D. Ungor, N. Ábrahám, V. Varga, D. Sebők, Á. Juhász, I. Dékány: Optical and Fluorescent properties of plasmonic nano-bioconjugates

SIWAN6, $6^{\text {th }}$ International Workshop on Advances in Nanoscience, 15-18 October, 2014, Szeged, Hungary

7. Dékány, L. Janovák, Sz. Tallósy, Á. Deák, J. Ménesi, M. Sztakó, Á. Juhász, N. Buzás, Characterization of antibacterial silver and copper nanoparticles functionalized $\mathrm{TiO}_{2}$ composite photocatalysts

COST Action CM1101 WG3/WG4 Meeting; 30 June -01 July, 2014, Belgrade, Serbia.

8. L. Janovák, Sz. P. Tallósy, J. Ménesi, Á. Deák, Á. Juhász, N. Buzás, I. Dékány, Development of photocatalyst/ polymer hybrid films for the inactivation of bacteria by visible light

COST Action CM1101 WG3/WG4 Meeting; 30 June -01 July, 2014, Belgrade, Serbia. 
9. Dékány, L. Janovák, Sz. Tallósy, Á, Veres, Z. Zhong, Á. Juhász, N. Buzás, Various $\mathrm{TiO}_{2}$ nanostructures for decomposition of ethanol and bacteria using visible light $8^{\text {th }}$ European Meeting on Solar Chemistry and Photocatalysis: Environmental Applications - SPEA8; 25-28 June, 2014, Thessaloniki, Greece.

10. Dékány, L. Janovák, Á. Deák, M. Sztakó, Á. Juhász, Properties of fluorinated acrylic copolymer/ $\mathrm{SiO}_{2}$ hybrid superhydrophobic surfaces with tuneable wettability

COST Action Workshop CM 1101 WG 2 and WG 5; Interactions in Colloidal Systems, 2426 March, 2014, TU Berlin, Institut für Chemie, Germany.

11. Dékány, L. Janovák, Sz. Tallósy, Á. Juhász, N. Buzás, Photocatalyst for decomposition of organic pollutants and bacteria using visible light

$3^{\text {rd }}$ European Symposium on Photocatalysis (JEP), 25-27 September, 2013, Portoroz, Slovenia. Abstract OC6-1.

12. S. Puskás, É. Bazsó, Á. Juhász, I. Dékány: Nanoemulziók szerkezete és tulajdonságai $27^{\text {th }}$ International Petroleum \& Gas Conference and Exhibition, 16-19 September, 2008, Siófok, Magyarország, Conference Proceedings on CD-ROM, pp. 1-22.

\section{Az értekezés témájához nem kapcsolódó poszter prezentációk:}

1. Á. Juhász, N. Varga, H. Szokolai, E. Csapó, Cross-linked and neutralized hyaluronic acid-based drug delivery systems

9th Global Chemistry Congress, 22-23 July, 2018, Lisbon, Portugal

2. E. Csapó, D. Ungor, B. Kismárton, Á. Juhász, I. Dékány, Nucleotide-directed syntheses of gold nanohybrid systems with structure-dependent optical features: Selective fluorescence sensing of $\mathrm{Fe}^{3+}$ ions

$7^{\text {th }}$ International Colloids Conference, 17-21 June, 2017, Barcelona-Sitges, Spain

3. E. Csapó, D. Ungor, Z. Kele, A. Juhász, L. Janovák, I. Dékány, Tuneable Optical Features of Amino Acid-stabilized Gold Nanoparticles and Nanoclusters

$5^{\text {th }}$ International Conference on Bio-Sensing Technology (BITE-2017), 5-10th May, 2017, Riva del Garda, Italy

4. E. Csapó, D. Ungor, Á. Juhász, D. Sebők, Sz. P. Tallósy, I. Dékány, Noble metal and protein nanohybrid systems for biomedical applications

$6^{\text {th }}$ International Colloids Conference, 19-22 June, 2016, Berlin, Germany

5. D. Ungor, E. Csapó, B. Kismárton, Á. Juhász, I. Dékány, Nucleotide-stabilized Au and $\mathrm{Au} / \mathrm{Ag}$ nanoclusters for biosensor applications

CTB2016, $28^{\text {th }}$ August $-1^{\text {st }}$ September, 2016, Brno, Czech Republic

6. L. Janovák, Á. Deák, E. Csapó, D. Sebők, Á. Juhász, N. Varga, N. Nánási, I. Dékány, Biocompatible hydrogel based nanostructured materials for controlled drug delivery $11^{\text {th }}$ Int. Conf. on Diffusion in Solids and Liquids, 22-25 June, 2015, München, Germany 
7. Sz. P. Tallósy, L. Janovák, J. Ménesi, E. Nagy, Á. Juhász, N. Buzás, I. Dékány, Adhesion and inactivation of Gram-positive and Gram-negative bacteria on different photocatalysts 8th European Meeting on Solar Chemistry and Photocatalysis: Environmental Applications - SPEA8; 25-28 June, 2014, Thessaloniki, Greece.

8. L. Janovák, Sz. Péter Tallósy, E. Csapó, Á. Juhász, N. Buzás, I. Dékány, Plasmonic metal nanoparticles modified photocatalyst hybrid films for photocatalytic decomposition of ethanol and its antibacterial properties

$8^{\text {th }}$ European Meeting on Solar Chemistry and Photocatalysis: Environmental Applications - SPEA8; 25-28 June, 2014, Thessaloniki, Greece

9. Sz.P. Tallósy, L. Janovák, J. Ménesi, E. Nagy, N. Buzás, Á. Juhász, I. Dékány, Antimicrobial activity of plasmonic photocatalysts in polymer nanohybrid layers against nosocomial pathogens

$3^{\text {rd }}$ European Symposium on Photocatalysis (JEP) 25-27 September, 2013, Portoroz, Slovenia. Abstract P6-2.

10. L. Janovák, Sz. P. Tallósy, Á. Juhász, N. Buzás, I. Dékány: Surface coating processes for preparation of photoreactive $\mathrm{TiO}_{2}$ and $\mathrm{ZnO}$ nanocomposite films

$3^{\text {rd }}$ European Symposium on Photocatalysis (JEP) 25-27 September, 2013, Portoroz, Slovenia. Abstract P6-1.

11. É. Bazsó, Á. Juhász, D. Sebők, N. Buzás, I. Dékány, S. Puskás, Influence of the hydrophilic-hydrophobic properties of surfactant mixtures on the droplet size and rheological behaviour of nanoemulsions

$5^{\text {th }}$ Szeged International Workshop on Advances in Nanoscience (SIWAN5), 24-27 October, 2012, Szeged, Hungary, Abstract P043

12. Sz. Tallósy, L. Janovák, E. Nagy, N. Buzás, Á. Juhász, I. Dékány, L. Balázs, I. Deme, Antimicrobial effect of silver functionalized $\mathrm{TiO}_{2}$ coated lamp surface in indoor air sample using LED light source

$5^{\text {th }}$ Szeged International Workshop on Advances in Nanoscience (SIWAN5), 24-27 October, 2012, Szeged, Hungary, Abstract. P003

13. E. Csapó, V. Hornok, Á. Juhász, M. Csete, I. Dékány, Characterization of amino acidand peptide-conjugated gold and silver nanoparticles

EuroNanoForum 2011, máj. 30. - jún. 1., 2011, Budapest, Magyarország

14. Á. Juhász, É. Bazsó, N. Buzás, I. Dékány, Solubilisation of paraffinic deposits using colloidal and nanostructured complex fluids

EuroNanoForum 2011, máj. 30. - jún. 1., 2011, Budapest, Magyarország.

15. S. Puskás, É. Bazsó, Á. Juhász, Zs. Czibulya, I. Dékány, Structural and rheological properties of o/w and w/o nanoemulsions using nonionic surfactant mixtures

$17^{\text {th }}$ International Symposium on Surfactants Solution (SIS2008), 22-27 August, 2008, Berlin, Németország 